\title{
Genetic Basis for Thermal Tolerance in Two Different Strains of Rainbow Trout (Oncorhynchus mykiss): Case Western and Kamloops
}

\author{
Paola Reale \\ West Virginia University
}

Follow this and additional works at: https://researchrepository.wvu.edu/etd

\section{Recommended Citation}

Reale, Paola, "Genetic Basis for Thermal Tolerance in Two Different Strains of Rainbow Trout (Oncorhynchus mykiss): Case Western and Kamloops" (2012). Graduate Theses, Dissertations, and Problem Reports. 3520.

https://researchrepository.wvu.edu/etd/3520

This Thesis is protected by copyright and/or related rights. It has been brought to you by the The Research Repository @ WVU with permission from the rights-holder(s). You are free to use this Thesis in any way that is permitted by the copyright and related rights legislation that applies to your use. For other uses you must obtain permission from the rights-holder(s) directly, unless additional rights are indicated by a Creative Commons license in the record and/ or on the work itself. This Thesis has been accepted for inclusion in WVU Graduate Theses, Dissertations, and Problem Reports collection by an authorized administrator of The Research Repository @ WVU. For more information, please contact researchrepository@mail.wvu.edu. 


\title{
Genetic Basis for Thermal Tolerance in Two Different \\ Strains of Rainbow Trout (Oncorhynchus mykiss): Case Western and Kamloops
}

\author{
Paola Reale
}

Thesis submitted to the

Davis College of Agriculture, Natural Resources and Design at West Virginia University in Partial fulfillment of the requirements for the degree of

Master of Science

in

Wildlife and Fisheries Resources

Kyle J. Hartman, Ph. D., Chair

Patricia M. Mazik, Ph. D.

Amy Welsh, Ph. D.

Jianbo Yao, Ph. D.

Division of Forestry and Natural Resources

Morgantown, West Viriginia

2012

Keywords: rainbow trout, heat shock protein, Case Western strain, Kamloops strain, Oncorhynchus mykiss, cortisol, HSP70, HSP90, red blood cells 


\title{
ABSTRACT \\ Genetic Basis for Thermal Tolerance in Two Different Strains of Rainbow Trout \\ (Oncorhynchus mykiss): Case Western and Kamloops
}

\author{
Paola Reale
}

This thesis examines the thermal tolerance based on how expression of Heat Shock Protein (HSP) 70 and HSP90 differ between two different strains of rainbow trout (Oncorhynchus mykiss), the Case Western strain and the Kamloops strain, and determines if cortisol levels affect HSP expression in red blood cells. The Case Western strain is considered the only warm water trout, only recently was any aspect of its thermal tolerance quantified. Porto (2012) determined critical thermal maxima (CTM) for the Case Western strain and found it to be about $0.15{ }^{\circ} \mathrm{C}$ higher than the Kamloops strain. This thesis is comprised of three chapters: (1) an introduction and literature review on the biological history of these two strains of rainbow trout, on studies related to HSPs expression as indicators of thermal tolerance, and studies on the relation between cortisol expression and HSPs expression; (2) an experimental study investigating the differences between HSP70 and HSP90 between the two strains, before and after a heat stress test and between individuals of different sizes; (3) an experimental study investigating the relation between the heat stress protein expression and cortisol levels pre- and post-stress. The results on the HSP70 and HSP90 relative expressions confirm that Case Western strain has higher thermal tolerance, highlighting the importance of this strain as a candidate to be cultured in aquaculture facilities as an answer to possible impacts of future climate changes. Earlier studies suggested HSP expression varied with age in rainbow trout, but failed to consider strain-specific differences. Our results show that agespecific HSPs expression is not species-specific in rainbow trout as it differs by strain. The results show that the plasma cortisol levels before and after thermal stress do not differ among strains, and that the physiological response to heat stress is species-specific. The variable that has the largest influence on the variance expressed among groups came from the HSP90 gene. We found the stressed Kamloops was the most diverse group, with less thermal tolerance, influenced mostly by the weight of the HSP90 on the total variance. 


\section{Acknowledgements}

First and foremost I would like to express my biggest gratitude to Dr. Kyle Hartman, who has provided me with all the resources to successfully complete my thesis and has always given me all of his support throughout the process. I would also like to thank the other members of the Graduate Committee, Dr. Patricia Mazik, Dr. Amy Welsh, and Dr. Jianbo Yao, whose knowledge and guidance made the process a lot easier for me to complete. Furthermore, I would like to thank Dr. Hao Ma for all of his help in completing this thesis, Dr. Kimberly M. Barnes for letting me use her laboratory to run the cortisol plate's reading, John Howell and Meghan Manor for the help during the sampling processes. Additionally, I would like to thank the Rotary Foundation, which provided me with the financial support to attend West Virginia University during the first year of my Masters.

I would also like to thank my family whose support pushed me to complete this project and persist even when things were very difficult and challenging. And last, but certainly not least, I would like to thank my future husband Juan, whose support, both emotional and academic, aided me in completing this degree successfully. 


\section{Table of contents}

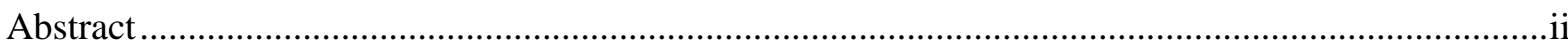

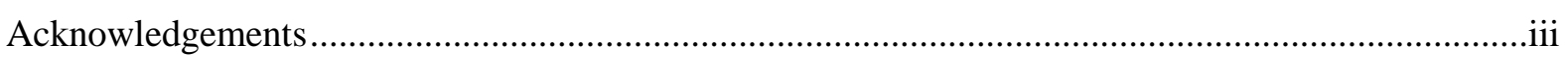

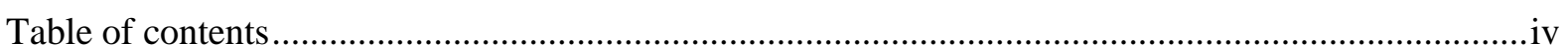

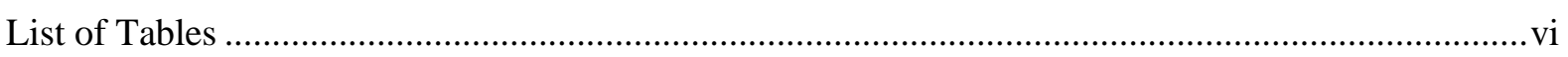

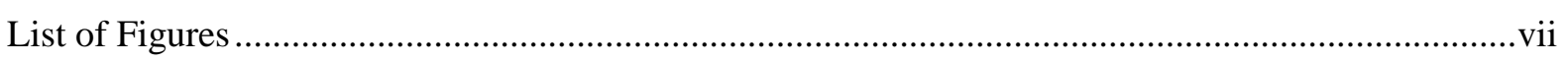

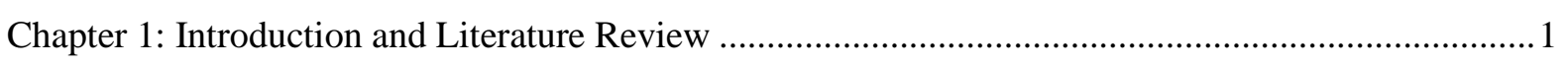

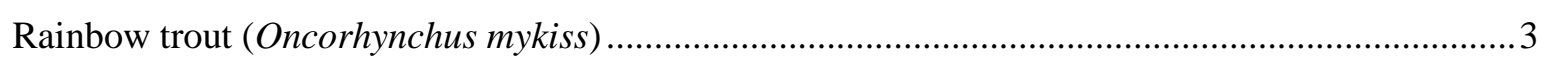

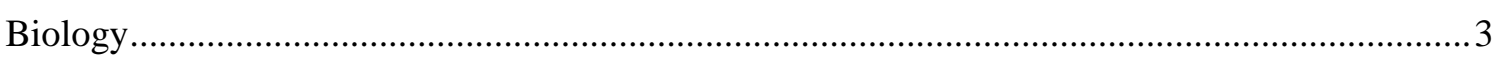

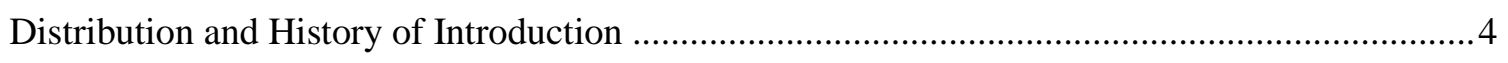

Tolerances of trout to environmental variables....................................................................... 4

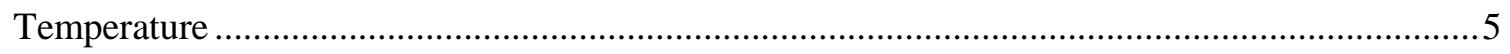

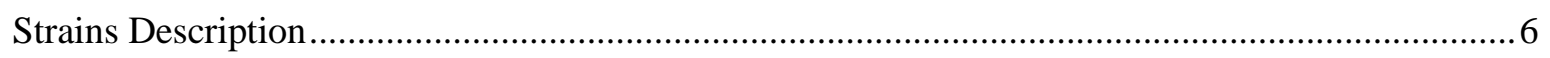

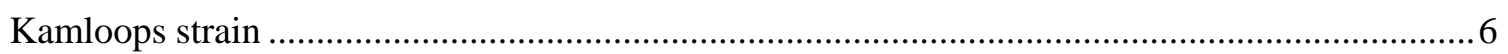

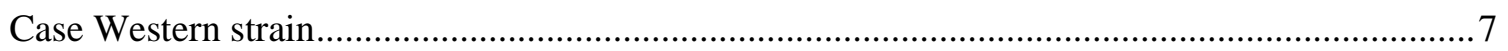

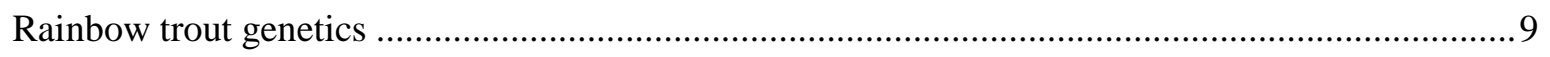

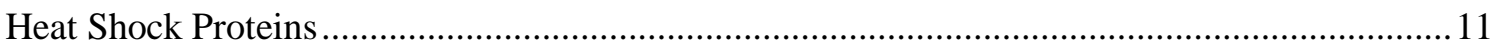

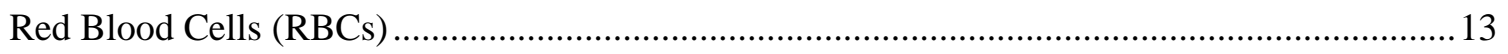

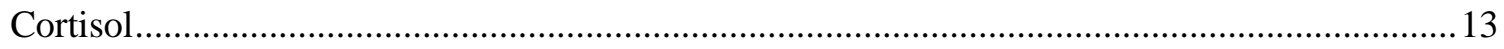

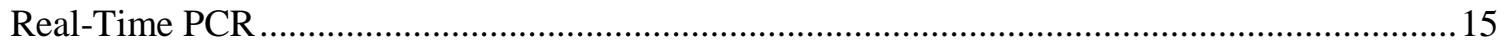

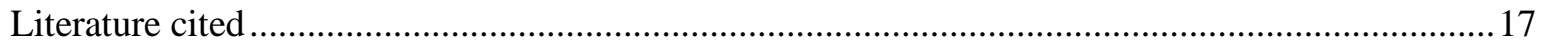

Chapter 2: Comparing the differences in thermal tolerance between the Case Western strain and the

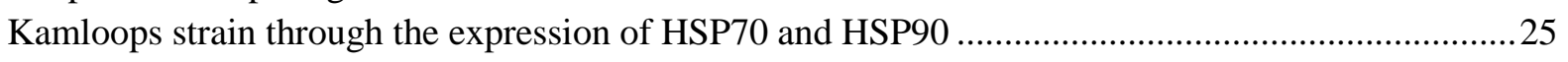

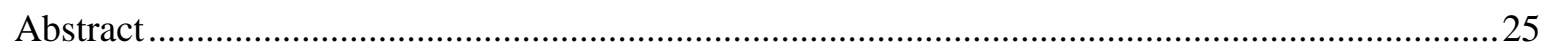

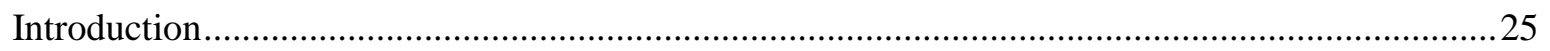

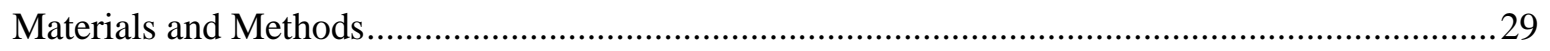

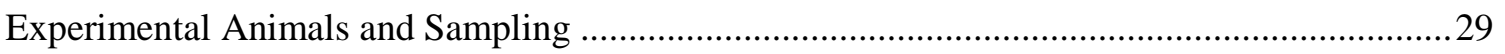

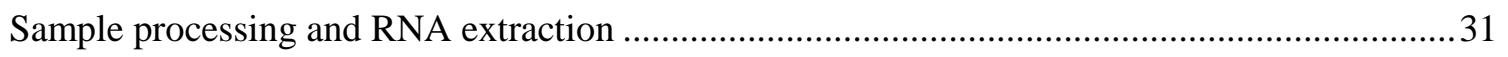

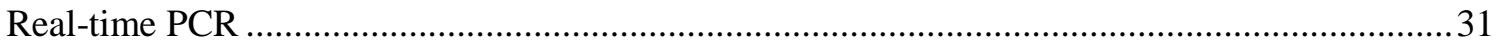

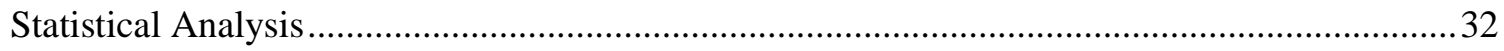

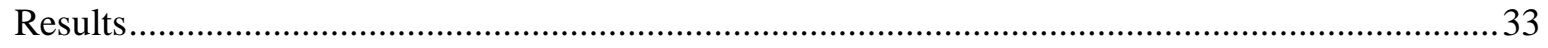

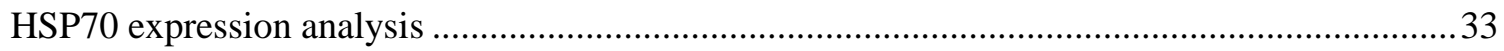

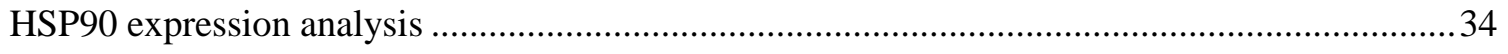

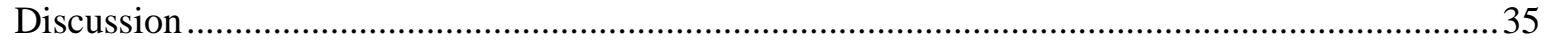

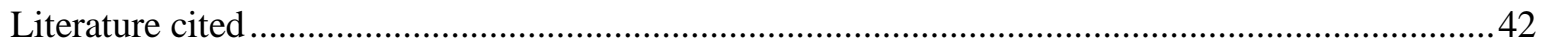


Chapter 3: Cellular and physiological responses to heat stress in two strains of rainbow trout (Oncorhynchus mykiss): Case Western and Kamloops strains

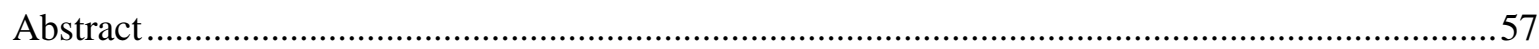

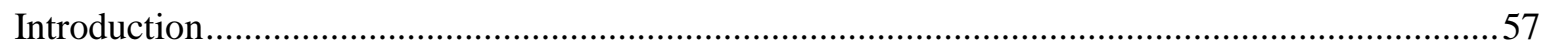

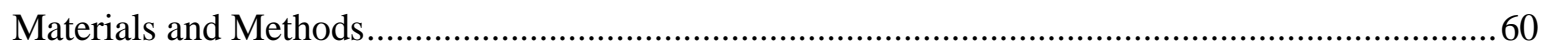

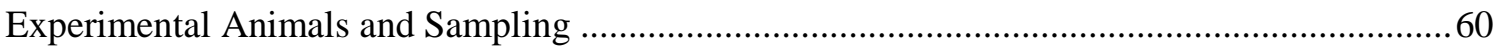

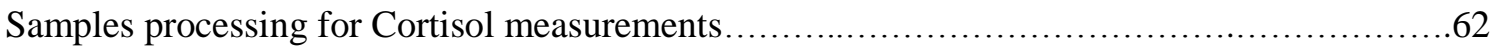

Samples processing for HSP70 and HSP90 genes relative expressions measurements..............63

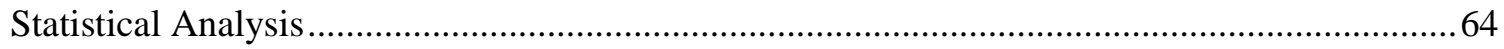

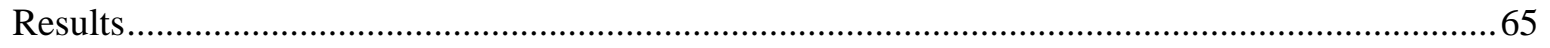

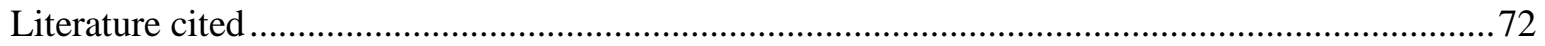




\section{List of Tables}

Table 2.1. Experimental design: time points representing an early and a late transcriptional response for Case Western strain $(\mathrm{CW})$, and Kamloops strain $(\mathrm{K})$. .46

Table 2.2. Primers used in real-time PCR: HSP70 f/r, HSP90 f/r, and the housekeeping gene BActin $\mathrm{f} / \mathrm{r}$

Table 2.3. One-way ANOVA results of the relative gene expression of HSP70 from QRTPCR analysis on the two strains of rainbow trout (O. mykiss) red blood cells (RBCs) sampled as control group. The p-value of 0.03142 shows a significant statistical difference between the two strains of rainbow trout (Case Western $v s$. Kamloops) in control condition. .48

Table 2.4. One-way ANOVA results of the relative gene expression of HSP70 from QRTPCR analysis on the two strains of rainbow trout (O. mykiss) red blood cells (RBCs) sampled immediately after the heat shock test $(\mathrm{t}=0 \mathrm{~h})$ that lasts 5 hours. The $\mathrm{p}$-value of 0.00009 shows a significant statistical difference between the two strains of rainbow trout (Case Western vs. Kamloops) at $\mathrm{t}=0 \mathrm{~h}$

Table 2.5. One-way ANOVA results of the relative gene expression of HSP90 from QRTPCR analysis on the two strains of rainbow trout (O. mykiss) red blood cells (RBCs) sampled as control group. The p-value of 0.00303 shows a significant statistical difference between the two strains of rainbow trout (Case Western $v s$. Kamloops) in control condition...........50

Table 3.1. Experimental design of the heat stress test done on Case Western strain (CW), and Kamloops strain $(\mathrm{K})$ rainbow trout. .76

Table 3.2. Primers used in real-time PCR: HSP70 f/r, HSP90 f/r, and the housekeeping gene BActin $\mathrm{f} / \mathrm{r}$

Table 3.3. The eigenvalues values, giving a measure of the variance accounted for by the corresponding eigenvectors (components) are given below for the two significant components. The percentages of variance accounted for by these components are also given .78

Table 3.4. Results of a non-parametric MANOVA to test for significant differences between the four groups under study, based on correlation distance measure (Anderson 2001). Shaded cells represent those group pairs with significant correlation. .79

Table 3.5. Literature cortisol levels for stressed and unstressed (control) rainbow trout (Oncorhynchus mykiss) .80 


\section{List of Figures}

Figure 1.1 Native North American distribution of Oncorhynchus mykiss. Modified from

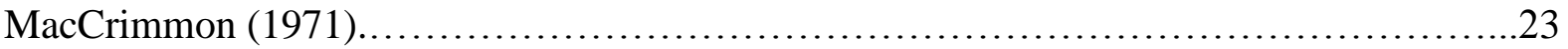

Figure 1.2 Main producer countries (shaded areas) of Oncorhynchus mykiss (FAO Fishery

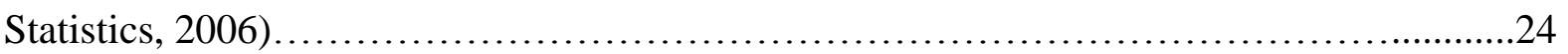

Figure 2.1 Agarose gel electrophoresis of RNA extracted from 8 samples.................51

Figure 2.2 Comparison of the relative gene expression of HSP70 from QRT-PCR analysis on the two strains of rainbow trout (O. mykiss) red blood cells (RBCs) sampled as control two weeks before the heat shock test. Vertical bars represent the relative gene expression values, and lines represent traces of individual response based on 40 individuals per strain. The error bars represent the standard error of the mean (SEM). The dark grey column represents the Case Western control group, and the light grey column represents the Kamloops control group

Figure 2.3. Comparison of the relative gene expression of HSP70 from QRT-PCR analysis on the two strains of rainbow trout (O. mykiss) red blood cells (RBCs): a) sampled immediately after the heat shock test $(\mathrm{t}=0 \mathrm{~h})$ that lasts 5 hours; $\mathrm{b})$ after 4 hours from the end of the heat stress test $(t=4 h) ; c)$ after 24 hours from the end of the heat stress test $(t=24 h)$; and $d)$ after 72 hours from the end of the heat stress test $(t=72 h)$. Vertical bars represent the relative gene expression values, and lines represent traces of individual response on 10 individuals per strain. The error bars represent the standard error of the mean (SEM). The dark grey column represents the Case Western strain, and the light grey column represents the Kamloops strain

Figure 2.4 Comparison of the relative gene expression of HSP90 from QRT-PCR analysis on the two strains of rainbow trout (O. mykiss) red blood cells (RBCs) sampled as control two weeks before the heat shock test. Vertical bars represent the relative gene expression values, and lines represent traces of individual response based on 40 individuals per strain. The error bars represent the standard error of the mean (SEM). The dark grey column represents the Case Western control group, and the light grey column represents the Kamloops control group....

Figure 2.5 Comparison of the relative gene expression of HSP90 from QRT-PCR analysis on the two strains of rainbow trout (O. mykiss) red blood cells (RBCs): a) sampled immediately after the heat shock test $(\mathrm{t}=0 \mathrm{~h})$ that lasts 5 hours; $\mathrm{b})$ after 4 hours from the end of the heat stress test $(t=4 h) ; c)$ after 24 hours from the end of the heat stress test $(t=24 h)$; and $d)$ after 72 hours from the end of the heat stress test $(t=72 h)$. Vertical bars represent the relative gene expression values, and lines represent traces of individual response on 10 individuals per strain. The error bars represent the standard error of the mean (SEM). The dark grey column represents the Case Western strain, and the light grey column represents the Kamloops strain 
Figure 2.6 Comparison of the relative gene expression of HSP70 and HSP90 from QRT-PCR analysis between the two ranges of age in each of the two strains of rainbow trout (O. mykiss) red blood cells (RBCs). The individuals GOI expressions were compared in their control state. Each strain comprehended 40 individuals of which 20 had 6 months and 201 year old. Vertical bars represent the relative gene expression values, and lines represent traces of individual response. The error bars represent the standard error of the mean (SEM). The dark grey column represents individuals of 6 months old, and the light grey column represents

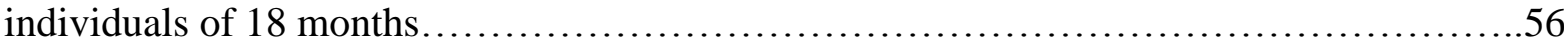

Figure 3.1 Agarose gel electrophoresis of RNA extracted from 8 samples

Figure 3.2 Comparison of the plasma cortisol concentration levels of the two strains of rainbow trout (O. mykiss) sampled as control two weeks before the heat shock test. Vertical bars represent the plasma cortisol concentrations $(\mathrm{ng} / \mathrm{ml})$, and lines represent traces of individual response based on 10 individuals per strain. The error bars represent the standard deviation from the mean (SD). The dark grey column represents the Case Western control group, and the light grey column represents the Kamloops control

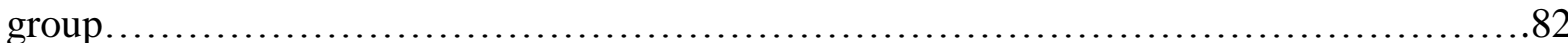

Figure 3.3 Comparison of the plasma cortisol concentration levels of the two strains of rainbow trout $(O$. mykiss) sampled immediately after the heat shock test. Vertical bars represent the plasma cortisol concentrations $(\mathrm{ng} / \mathrm{ml})$, and lines represent traces of individual response based on 10 individuals per strain. The error bars represent the standard deviation from the mean (SD). The dark grey column represents the Case Western control group, and the light grey column represents the Kamloops control group.........................83

Figure 3.4 Comparison of the relative gene expression of HSP70 from QRT-PCR analysis on the two strains of rainbow trout (O. mykiss) red blood cells (RBCs) sampled as control two weeks before the heat shock test. Vertical bars represent the relative gene expression values, and lines represent traces of individual response based on 10 individuals per strain. The error bars represent the standard error of the mean (SEM). The dark grey column represents the Case Western control group, and the light grey column represents the Kamloops control group.

Figure 3.5 Comparison of the relative gene expression of HSP70 from QRT-PCR analysis on the two strains of rainbow trout (O. mykiss) red blood cells (RBCs) sampled immediately after the heat shock test. Vertical bars represent the relative gene expression values, and lines represent traces of individual response on 10 individuals per strain. The error bars represent the standard error of the mean (SEM). The dark grey column represents the Case Western control group, and the light grey column represents the Kamloops control group

Figure 3.6 Comparison of the relative gene expression of HSP90 from QRT-PCR analysis on the two strains of rainbow trout (O. mykiss) red blood cells (RBCs) sampled as control two weeks before the heat shock test. Vertical bars represent the relative gene expression values, 
and lines represent traces of individual response based on 10 individuals per strain. The error bars represent the standard error of the mean (SEM). The dark grey column represents the Case Western control group, and the light grey column represents the Kamloops control group.

Figure 3.7 Comparison of the relative gene expression of HSP90 from QRT-PCR analysis on the two strains of rainbow trout (O. mykiss) red blood cells (RBCs) sampled immediately after the heat shock test. Vertical bars represent the relative gene expression values, and lines represent traces of individual response on 10 individuals per strain. The error bars represent the standard error of the mean (SEM). The dark grey column represents the Case Western control group, and the light grey column represents the Kamloops control group

Figure 3.8 Principal Component Analysis graph, showing the first (57.04\% of variance explained) and second (32.60\% of variance explained) components. The convex hulls show the distribution of the four groups under study: Case Western strain in control state (red pluses), Kamloops in control state (blue empty squares), Case Western in stressed state (fuchsia squares), and Kamloops in stressed state (green crosses) .88

Figure 3.9 Histogram showing the correlation coefficients of each original variable with the first component.

Figure 3.10 Histogram showing the correlation coefficients of each original variable with the second component. 


\section{Chapter 1: Introduction and Literature Review}

This thesis examines the thermal tolerance based on how expression of Heat Shock Protein (HSP) 70 and HSP90 differ between two different strains of rainbow trout (Oncorhynchus mykiss), the Case Western strain and the Kamloops strain, and determines if cortisol levels affect HSP expression in red blood cells. The Case Western strain is considered the only warm water trout, only recently was any aspect of its thermal tolerance quantified. Porto (2012) determined critical thermal maxima (CTM) for the Case Western strain and found it to be about $0.15{ }^{\circ} \mathrm{C}$ higher than the Kamloops strain. This thesis is comprised of three chapters: (1) an introduction and literature review on the biological history of these two strains of rainbow trout, on studies related to HSPs expression as indicators of thermal tolerance, and studies on the relation between cortisol expression and HSPs expression; (2) an experimental study investigating the differences between HSP70 and HSP90 between the two strains, before and after a heat stress test and between individuals of different sizes; (3) an experimental study investigating the relation between the heat stress protein expression and cortisol levels pre- and post-stress. The results on the HSP70 and HSP90 relative expressions confirm that Case Western strain has higher thermal tolerance, highlighting the importance of this strain as a candidate to be cultured in aquaculture facilities as an answer to possible impacts of future climate changes. Earlier studies suggested HSP expression varied with age in rainbow trout, but failed to consider strain-specific differences. Our results show that age-specific HSPs expression is not species-specific in rainbow trout as it differs by strain. The results show that the plasma cortisol levels before and after thermal stress do not differ among strains, and that the physiological response to heat stress is species-specific. The variable that has the largest influence on the variance expressed among groups came from the HSP90 gene. We found the stressed Kamloops was 
the most diverse group, with less thermal tolerance, influenced mostly by the weight of the HSP90 on the total variance.

Furthermore, expression levels of HSPs in red blood cells for rainbow trout have never been compared between two different strains. Thus the current investigation could provide valuable information for aquaculture and fisheries fields. Our hypothesis is that individuals belonging to the Case Western strain, being the only registered strain of rainbow trout that originates from a warm water brood stock according to the National Fish Strain Registry (Kincaid et al., 2001), will show a lower expression of the heat shock proteins compared to the Kamloops strain due to the Case Western strain's tolerance of high temperatures. Furthermore, our hypothesis for the cortisol levels is that the strains will show a similar concentration of cortisol in control state and in stressed state, being both strains maintained in an identical environment.

Salmonids have long been of great interest due to the commercial and recreational value of the majority of the species, and they are becoming increasingly important as model systems for addressing a wide range of evolutionary and ecological questions (Groot and Margolis, 1991; Hendry and Stearns, 2003). They are one of the most widely studied groups of fish worldwide due to their high economic value, growth rate, interesting biological cycle and history of translocation across many continents. Furthermore, the salmonids industry has had an explosive growth rate since the 1980s (Dunham et al., 2001). Their production requires cold water, high oxygen content, and low levels of pollutants. Nowadays $40 \%$ of the salmonids produced in captivity are derived from the Southern Hemisphere, even if the majority originated from the Northern Hemisphere. There are two main reasons why rainbow trout was chosen for this study. First, rainbow trout has a long history of aquaculture worldwide; and second, because it is one of the most widely studied model fish species, 
which provides a vast amount of biological information that has already been collected as a result of its widespread use in research.

\section{Rainbow trout (Oncorhynchus mykiss)}

\section{Biology}

Rainbow trout are coldwater fish that have long been symbolic of clear, healthy mountain streams and lakes in North America (steelhead may be found in estuaries or oceans). They prefer complex structures, such as riffles, submerged wood and boulders, and aquatic vegetation. Small juvenile rainbow trout are benthopelagic while larger juveniles are pelagic (Mundy, 2005), with anadromous forms inhabiting freshwater, brackish and marine environments (steelhead strain).

The rainbow trout has many small spots extended across its body upper part. The back is brassy green, while the bottom part is white or gray. A wide pink or red band marks the sides, with more intense colors during the reproductive period. The body form is spindleshaped, and the mouth being a predator is terminal and large. A fleshy adipose fin is present between the dorsal and caudal fins. Scales are cycloid, very small, and embedded under a thick mucus layer.

Small juveniles are benthopelagic while larger juveniles are pelagic. Brayton (1981) sets maturity at one year and longevity at three or four years in Virginia, while Carlander (1969) indicates that longevity is seven years. During the course of artificial cultivation, this species has been widely crossbred. Because of crossbreeding, there is an impressive variety of types of strains of Oncorhynchus mykiss, where the main difference is the spawning season. 


\section{Distribution and History of Introduction}

Rainbow trout is a species of salmonid that historically was found around the North Pacific Ocean from northwestern Mexico in North America to eastern Russia in Asia (Clemento et al., 2009). Since 1874 the range of the rainbow trout has been extended from western North America to include waters on all continents except Antarctica. Richardson first described the species in 1836 from specimens captured in the Columbia Rivers (La Rivers, 1962). Since that time, various specific names have been given to local forms, generally based on phenotypic differences. Outstanding characteristics of the California golden trout (aguabonita) and the Gila trout (gilae), along with geographic isolation, have led to persistence of these local forms as distinct species recognized by the American Fishery Society (Bailey et al., 1960). The natural range for rainbow trout in North America extends from Alaska to Mexico and includes British Columbia, Washington, Oregon, California, Idaho, and Nevada (U.S.D.A., 2000) (Figure 1.1).

The species has been introduced for food or recreational sport to at least 45 countries, and every continent except, as said above, to Antarctica (Figure 1.2). Rainbow trout were first introduced outside their native range in 1874, when S. Green transferred a small consignment of eyed eggs from the McCloud River in northern California to his private hatchery in Caledonia, New York (Wales, 1939). In some locations (Southern Europe, Australia and South America), they have negatively impacted native fish species, either by eating them, competing with them, transmitting diseases, or hybridizing with closely related species and subspecies that were native to western North America (Crivelli, 2006).

\section{Tolerance of trout to environmental variables}

The tolerance of fish to a single environmental variable has often been tested to determine the range of a variable under which a species of fish could survive. The most often 
tested variables are the physical ones, because ectothermic animals can survive within a range of a single physical variable before regulatory mechanisms and the animal collapse. Instinctive reactions of rainbow trout are: to move toward an area where the variable is at a favorable level for the animal; to expend more energy in regulatory mechanisms at the expense of growth and/or reproduction; and die if a mortal extreme is reached (Molony, 2001).

Most animals possess a wide tolerance to a single variable. For example, rainbow trout can survive in waters with temperatures between approximately $0.0{ }^{\circ} \mathrm{C}$ and $29.8{ }^{\circ} \mathrm{C}$ (Rodgers and Griffiths, 1983; Elliott and Elliott, 1995; Currie et al., 1998). However, within this temperature range for survival, trout have a preferred range in which growth, reproduction and/or other physiological characteristics are optimized (Peterson and Meador, 1994).

\section{Temperature}

Temperature is the most often tested variable in many fish studies, included studies involving trout. Rainbow trout can adapt to a variety of habitats, with proper temperature, water-quality conditions, and flow regimes. Being poikilotherms, trout cannot regulate their own body temperature and completely depend on favorable habitat being available to survive and grow. Rainbow trout can be found between $6{ }^{\circ} \mathrm{C}\left(44^{\circ} \mathrm{F}\right)$ and $23{ }^{\circ} \mathrm{C}\left(75^{\circ} \mathrm{F}\right)$, however, the optimal temperature for rainbow trout is $12{ }^{\circ} \mathrm{C}\left(54^{\circ} \mathrm{F}\right)$. A critical and dangerous situation for trout happens during the hot season, where the shallow rivers and dammed waters commonly exceed $25^{\circ} \mathrm{C}$, approaching a potentially critical temperature for trout survival (Currie et al., 1998), despite some studies that found the upper thermal tolerance of rainbow trout to be between $24{ }^{\circ} \mathrm{C}$ (Eaton et al., 1995) and $32{ }^{\circ} \mathrm{C}$ (Myrick and Cech, 2000). 
From several studies, the critical thermal maxima (CTM) for rainbow trout are approximately $24-26{ }^{\circ} \mathrm{C}$ (Bidgood, 1980). [CTM's are calculated by steadily increasing the temperature of a water body until fish movements become disorganized and/or its sense of balance is upset and normal activity is no longer possible (Currie et al., 1998)]. However, some studies have found lower and higher CTMs depending on thermal history of the fish and life stage. For example, Rodgers and Griffiths (1983) found trout could survive higher temperatures (to $29^{\circ} \mathrm{C}$ ) if excess food was available. Ojolick et al. (1995) and Benfey (1996) recorded that the CTM for brook trout (Salvelinus fontainalis, a closely related salmonid) was up to $29.8{ }^{\circ} \mathrm{C}$, depending on the age and sex of the fish. Furthermore, Benfey (1996) concluded that females had higher CTMs than males, and that younger fish were better able to survive higher temperatures than older fish. Thus, it seems that young fish may be most tolerant of temperature extremes.

A large number of studies have also examined the effect of low temperatures on survival. The overall conclusion is that the critical thermal minimum of rainbow trout is approximately $1{ }^{\circ} \mathrm{C}$ (Finstad et al., 1988) to $2^{\circ} \mathrm{C}$ (Belkovskiy et al., 1991). Altering the acclimation temperature of fish and the rate of change can modify the CTM for trout. In many cases, increasing the acclimation temperature by $5{ }^{\circ} \mathrm{C}$ increases the $\mathrm{CTM}$ by $1{ }^{\circ} \mathrm{C}$, between acclimation temperatures of $10-20{ }^{\circ} \mathrm{C}$ (Currie et al., 1998), although studies involving higher acclimation temperatures are rare (Kaya, 1978).

\section{Strains Description}

\section{Kamloops strain}

The first strain of rainbow trout used for this research is the Oncorhynchus mykiss Kamloops (Jordan, 1892). Kamloops rainbow trout has been discovered in the upper Columbia and Fraser Rivers of British Columbia. It was first classified in 1992 as 
Oncorhynchus kamloops under the mistaken belief it represented a landlocked species of Pacific salmon. Kamloops are distinct and different from other rainbow trout in terms of their fighting ability and physical characteristics. Kamloops rainbow trout are glorified for their peculiar characteristics: fast growth, vibrant color, and ability to withstand stress. The reason why this strain is being used in this study is because it is one of the most widely stocked strains of rainbow trout across the country. The gene expression of proteins responsible for the thermal tolerance (HSP70 and HSP90) of the Kamloops strain will be compared with the gene expression for the same proteins for another strain of rainbow trout, the Case Western strain. This comparison will be performed in order to detect if there are genetic differences between the two strains' tolerance of higher temperatures.

\section{Case Western strain}

The Case Western strain is a strain of rainbow trout that is reputed to tolerate stressful temperature exposure better than other strains of rainbow trout. Dr. Mits Teraguchi at Case Western Reserve University discovered the strain in the early 1980's, as the byproduct of ecological pond experiments. The trout were placed in experimental ponds and the researchers forgot about them, leaving them in the ponds during the summer season. During the fall, they found out that the trout were still alive, having survived temperatures that were thought to be lethal to rainbow trout. From then on the Case Western strain is the only registered strain of rainbow trout that originates from a warm water brood stock according to the National Fish Strain Registry (Kincaid et al., 2001).

The Case Western strain was believed to grow well at temperatures near the reported upper thermal tolerance of rainbow trout $\left(25-26^{\circ} \mathrm{C}\right)$ in an aquaculture setting, but Porto's study (2012) found that growth of Case Western strain was lowest of the three strains tested at $20-22{ }^{\circ} \mathrm{C}$. Since the strain was sold in the early 1990 's to Laurel Hill Trout Farm, Inc. 
(Somerset, PA), there has been no selection for thermal tolerance placed on the individuals of this strain. Therefore the Case Western life history brings up the inquiry of whether this particular strain truly does possess this thermal tolerance it was thought to have or if it has been lost due to a lack of selective pressure that has not been enforced. Porto (2012) did a recent study where actual thermal tolerance of the Case Western rainbow trout was documented and compared to other common strains in a controlled laboratory setting, and an additional aquaculture setting. My study will focus on identifying two thermal regulating genes responsible for the higher thermal tolerance of the Case Western rainbow trout (HSP70 and HSP90). A brood stock will be created after individuals with high thermal tolerance levels are identified, which will hopefully allow the passing of this particular trait to future generations of trout.

The Case Western trout is a very special and rare case amongst other types of trout. Several studies suggest that wild fish are much more fit and genetically superior than captivereared fish in natural environments as a consequence of domestication selection (Lynch and O’Hely, 2001; Ford, 2002; Frankham et al., 2002). It would be uncommon for fitness weakening after one or a couple of generations caused by relaxed natural selection unless salmon have an abnormally high mutation rate or carry a vast standing genetic load. This theory could potentially prove to be accurate if selection acts on a single trait, under which condition these declines are possibly providing the quality of heritable conditions of the trait under selection is very elevated, and the selection is very strong. The range of heritability and selection coefficients required in order to drive these quick fitness declines becomes a lot less obstructive, as long as selection acts on multiple traits throughout the life cycle. Viability selection appears to be very limited by the high survival rates in hatchery, but that does not mean that a strong selection cannot be found later in the life cycle on phenotypic variation, which could also be revealed during the hatchery phase of the life cycle. 


\section{Rainbow trout genetics}

Rainbow trout are the most-widely cultivated cold freshwater fish and an important model species for many scientific areas, with a global production of 576,289 metric ton and valued at $\$ 2.39$ billion (FAO, 2010). Because of its worldwide cultivation, there is a great need for genetic improvement for aquaculture production efficiency and product quality, justifying the continued development of new genetic resources facilitating selective breeding (Palti et al., 2011).

Most of the rainbow trout strains cultured around the world are thought to originate from the McCloud River hatchery in California (Gall and Crandell, 1992). Since then, many strains of rainbow trout have been developed by selective breeding and crossbreeding with the goal of improving economically important traits like growth rate, viability, disease resistance, age at maturity, time of spawning, flesh quality etc. (Gjedrem, 2000).

Most fishes in aquaculture are still only exploited captives, but a few are on the threshold of becoming domesticated, most for the aquarium industry. Even if the long captivity history of rainbow trout (Behnke, 2002), used in aquaculture for human food, is well known and there are several separate hatchery strains, there are still no true domesticated forms that are known (Balon, 2004).

Genetic maps characterizing the inheritance patterns of traits and markers have been developed for a wide range of species and used to study questions in biomedicine, agriculture, ecology and evolutionary biology (Rexroad et al., 2008). The status of rainbow trout genetic maps has progressed significantly over the last decade due to interest in this species in aquaculture and sport fisheries, and as a model research organism for different studies (Rexroad et al., 2008). Rexroad et al. (2008) constructed a second-generation genetic map for rainbow trout using microsatellite markers to facilitate the identification of 
quantitative trait loci for traits affecting aquaculture production efficiency and the extraction of comparative information from the genome sequences of model fish species.

These discoveries are useful for preliminary investigations of the potential for the translocation of specific strains of trout to new locations, which may be at the extremes of trout tolerance, such as the high temperatures experienced during the summer in Case Western University. Furthermore, there may be an opportunity to develop or improve strains more tolerant to local environmental conditions, including high temperatures. Water temperature influences, as well as dissolved oxygen, are very important and critical for a fish's survival, growth, and reproduction.

Gene expression is a process in which genes encode proteins and proteins dictate cell function. Therefore, the thousands of genes expressed in a particular cell determine what that cell can do. Moreover, each step in the flow of information from DNA to RNA to protein provides the cell with a potential control point for self-regulating its functions by adjusting the amount and type of proteins it manufactures (Nature Education, 2011).

The amount of a particular protein in a cell, at any particular time, reflects the equilibrium between that protein's synthetic and degradative biochemical pathways. The production of proteins starts with the transcription from DNA to RNA and continues with the translation from RNA to protein. The control of these processes that balance the two different biochemical pathways plays a critical role in determining which kind of proteins are present in a cell and their specific amounts. Furthermore, the way in which a cell processes its RNA transcripts and newly made proteins also greatly influences protein levels.

The amounts and types of mRNA in a cell reflect the function of the cell. Thousands of transcripts are produced at every moment in every cell. The primary control point for gene expression is at the very beginning of the protein production process - the initiation of 
transcription. RNA transcription makes an efficient control point because many proteins can be made from a single mRNA molecule (Nature Education, 2011).

Eukaryotic transcripts are more complex than prokaryotic transcripts. For example, the primary transcripts synthesized by RNA polymerase contain sequences that will not constitute mature RNA. These intervening sequences are the introns, and they are removed before the mature mRNA leaves the nucleus (Nature Education, 2011). The remaining regions of the transcript, which include the protein-coding regions, are called exons, and they are spliced together to produce the mature mRNA. Eukaryotic transcripts are also modified at their ends, which affects their stability and translation (Nature Education, 2011).

\section{Heat Shock Proteins}

Stressed fish exhibit a generalized stress response that is characterized by an increase in stress hormones and the consequent changes at the physiological, organismal, and population levels (Barton, 1997; Bonga, 1997). The stress response in fish has a genetic component (Pottinger and Pickering, 1997), thus there are differences in the generalized stress response among different fish species, strains and individuals, differing in the tolerance to different stressors. The observed stress response is therefore an expression of both genetic and environmental factors such as season, rearing history, and nutritional states (Iwama et al., 1992).

One of the most common features of the cellular stress response is the production of heat shock proteins (HSPs) in response to stressors that threaten the life of the cell, which is dependent upon the maintenance of protein integrity and function (Iwama et al., 1999). Since their first discovery by Ritossa (1962), HSPs have become one of the most well studied indicators of heat stress and protein damages (Lund et al., 2003), being highly conserved, extremely sensitive, and rapid indicators of cellular stress when examined at the mRNA level. 
Heat shock proteins are molecular chaperones that assist the cell in folding, fidelity, and translocation. They protect vital cellular functions by inhibiting faulty interactions that may produce pointless structures or processes (Ellis, 1993; Maresca and Lindquist, 1991). They are the cell's response to stress. HSPs expression increases as a response to heat shock in the same manner in many organisms from bacteria to humans (Hofmann, 1999; Maresca and Lindquist, 1991).

Extensive studies on model species have revealed three major families of heat shock proteins: HSP90 (85-90 kDa), HSP70 (68-73 kDa), and low molecular weight heat shock proteins $(16-47 \mathrm{kDa})$. In the unstressed cell, these proteins have constitutive functions that are essential in various aspects of protein metabolism.

HSP90 is active in supporting various components of the cytoskeleton and steroid hormone receptors (Young et al., 2001). HSP70 is known to assist the folding of nascent polypeptide chains, act as molecular chaperone, and mediate the repair and degradation of altered or denatured proteins (Kiang and Tsokos, 1998). HSP70 is the most commonly expressed protein in response to thermal stress (Heredia-Middleton et al., 2008).

The low molecular weight heat shock proteins have diverse functions that are speciesspecific. They have no known constitutive function and are only induced during stress (Ciocca et al., 1993). Smaller HSPs may offer reasonable potential for diagnostic purposes among species or strains, whereas the larger HSPs may serve as indicators of non-specific stressors in a wide range of organisms. 


\section{Red Blood Cells (RBCs)}

HSPs have been identified in almost all vertebrate tissues, including the red blood cells (RBCs) of some species. Fish RBCs are nucleated and are thus capable of heat shock gene transcription and translation (Currie and Tufts, 1997).

The ability to easily collect and manipulate blood in nonterminal experiments makes blood an ideal tissue on which to study the cellular temperature stress response on rainbow trout (Lewis et al., 2010). Furthermore the possibility to extract mRNA for further genetics analysis by sampling blood allowed us to monitor repeatedly the same individual (Iwama et al., 1998). We were able to track the stress response to temperature at the mRNA level of an individual over time. It is an easier way to compare the evolution and modifications in HSPs gene expression for the same individual and have a more consistent and informative result.

\section{Cortisol}

The generalized stress response in fish has been broadly categorized into the primary, secondary, and tertiary response (Wedemeyer et al., 1990). The primary response is the initial response, representing the perception of an altered state and the initiation of neuroendocrine/endocrine response from fish (Gamperl et al., 1994). It includes the rapid release of stress hormones, catecholamines and cortisol, into the circulation.

Cortisol is released from the interregnal tissue, located in the head kidney, in response to several pituitary hormones, but mostly to adrenocorticotrophic hormone (ACTH) (Wendelaar Bonga, 1997). The resting and stressed levels of cortisol concentrations in the plasma of salmonids, according to Iwama et al. (1998), is <10 and 40-200 (ng ml-1), respectively. 
The secondary response comprises the various biochemical and physiological effects associated with stress, and mediated to a large extent by the above stress hormones (Iwama et al., 1999). The stress hormones activate a number of metabolic pathways that result in alterations in blood chemistry including plasma glucose concentrations and hematology (Vijayan et al., 1997b).

The tertiary response represents whole animal and population level changes associated with stress (Iwama et al., 2004). These changes may occur as a result of the repartitioning of energy by diverting energy substrates to cope with enhanced energy demand associated with stress and away from vital life processes such as reproduction and anabolic processes such as growth (Vijayan et al., 1997b).

Some studies [Pottinger and Pickering, (1997); Lund et al., (2003); Iwama et al., (2004)] provide insights into how the generalized stress response and HSPs expression may be related. The stressors may not be acting directly on the cells to induce HSPs expression, but it may be acting through a neuroendocrine pathway in the whole animal. The majority of the studies were done on the relation between the stress hormones and the HSP70, showing that this relation may not be of a simple cause-effect nature, but may be modulated by several factors in vivo. Mazur (1996) has shown that prior handling of rainbow trout increases the plasma cortisol levels (acute stress response) and the expression of the HSP30 and HSP70 in the gill tissue. In contrast Vijayan et al. (1997b) show that physical handling causes increased values of plasma cortisol, but that handling stress does not elicit HSP70 expression in the liver tissue. No studies have been done on the comparison between the level of cortisol due to handling stress and the expression of HSP70 in the red blood cells. 


\section{Real-Time PCR}

To analyze specific mRNAs, real-time quantitative polymerase chain reaction (realtime - PCR) will be used. Real-time PCR is a laboratory technique based on the PCR (Vrieling et al., 1988), which is used to amplify and simultaneously quantify a targeted DNA molecule. The fact that real-time PCR does the amplification and the quantification in a single reaction (multiplexing) (Edwards et al., 1993) has made it a truly high throughput assay and the result is a complementary DNA (cDNA) molecule (Dale and von Schantz, 2002). Real-Time PCR allows mRNA to be copied into cDNA using the enzyme reverse transcriptase, nucleotide triphosphates and oligo dT primers or random hexamers. The resulting hybrid mRNA and cDNA strand is denatured and the single stranded cDNA is used as a template for the second strand cDNA (the copy of the mRNA strand). This cDNA can be amplified by PCR, using specific primers, for the gene of interest (Dale and von Schantz, 2002).

Real-Time PCR is a very sensitive assay that enables detection of a specific mRNA in a single cell (Dale and von Schantz, 2002). Due to this characteristic, the technique is employed to detect mRNA that is available only in low copies or in a limited quantity of cells. Real-Time PCR in this experiment will be used to evaluate gene expression in a panel of tissues, more precisely on blood samples.

The procedure of the real-time PCR follows the general principle of the classic polymerase chain reaction; its main feature is that the amplified DNA is detected as the reaction progresses in real time, and can be monitored step by step on a computer. Because of that, this new approach shows a higher sensitivity and precision than the standard PCR, where the products of the reaction are detected at the end of the reaction. Furthermore, realtime PCR detects the accumulation of amplicon during the reaction. The data is then 
measured at the exponential phase of the PCR reaction. The exponential phase is the optimal point for analyzing data. Real-time PCR makes quantitation of DNA and RNA easier and more precise than past methods, allowing quantifying the gene expression with accuracy.

The type of real-time PCR assay that will be used for this study uses SYBR green dye. This dye is added to the PCR mixture and incorporates itself into double stranded DNA; hence the PCR products fluoresce (Boeckman et al., 2000).

The SYBR green dye will also bind to nonspecific, double stranded DNA that may be produced during the PCR reaction, such as primer dimers (Brisson et al., 2000). Therefore, a melting curve is employed to distinguish the specific products from the nonspecific products (Brisson et al., 2000). In addition, the PCR products may be confirmed by resolving them on a $2 \%$ agarose gel. If there are nonspecific products present, then primers should be redesigned in order to produce the specific target gene.

The main objective of this study is to determine there are differences in HSPs expression between the Case Western strain and the Kamloops strain, developed in the following second chapter. The identification of this difference has been done using a selected number of genes involved in the thermal tolerance and detecting gene expression differences to quantitatively measure the amount of relative mRNA expressed and consequently the differences between the two strains. The candidate genes are the heat shock proteins: HSP70 (Currie et al., 2000; Lewis et al., 2010) and HSP90 (Lewis et al., 2010). As a housekeeping gene (control gene), the Beta-Actin gene is used.

The third and last experimental chapter of this thesis focuses on determining if cortisol levels affect HSPs expression in RBCs. No studies on rainbow trout have been done on the comparison between the level of cortisol and the expression of HSP70 and HSP90 in the red blood cells. 


\section{Literature cited}

Bailey, R.M., Lachner, E.A., Lindsey, C.C., Robins, C.R., Roedel, P.M., Scott, W.B., and Woods, L.P., 1960. A list of common and scientific names of fishes from the United States and Canada. 2nd edition. American Fisheries Society Special Publication 2. Ann Arbor, Michigan.

Balon, E.K., 2004. About the oldest domesticates among fishes. Journal of Fish Biology. 65 (Suppl.A), 1-27.

Barton, B.A., 1997. Stress in finfish: Past, present, and future - a historical perspective. In Fish stress and health in aquaculture. Edited by Iwama GK, Pickering AD, Sumpter JP, Schreck CB. Cambridge: Cambridge University Press. 1-33

Behnke, R.J., 2002. Trout and Salmon of North America. New York: The Free Press.

Belkovskiy, N.M., Lega, Y.V., and Chernitskiy, A.G., 1991. Disruption of water-salt metabolism in rainbow trout, Salmo gairdneri, in seawater at low temperatures. J.Ichth. 31: 134-141.

Benfey, T.J., 1996. Use of all-female and triploid salmonids for aquaculture in Canada. Bull.Aquaculture Assoc. Can. 2, 6-8.

Bidgood, B.F., 1980. Tolerance of rainbow trout to direct changes in water temperature. Fish. Res. Rep. Fish Wildl. Div. 15, 11p

Boeckman, F., Hamby, K., and Tan, L., 2000. Real-Time PCR using the iCycler iQ Detection System and Intercalation Dyes. Bio-Rad Tech note 2684 (Amplification). Bio-Rad Laboratories, Inc. 1-2.

Brayton, S.L., 1981. Reproductive biology, energy content of tissues, and annual production of rainbow trout (Salmo gairdneri) in the South Fork of the Holston River, Virginia. Master's Thesis, Virginia Polythechnic Institute and State University, Blacksburg.

Brisson, M., Tan, L., Park, R., and Hamby, K., 2000. Identification of Nonspecific Products Using Melt-Curve Analysis on the iCycler iQ Detection System. Bio-Rad Tech note 2684 (Amplification). Bio-Rad Laboratories, Inc. 1-6.

Bustin, S.A., Benes, V., Nolan, T., and Pfaffl, M.W., 2005. Quantitative real-time RT-PCR: a perspective. Journal of Molecular Endocrinology. 34, 597-601.

Carlander, K.D., 1969. Handbook of freshwater fishery biology. Vol. 3: Life history data on freshwater fishes of the United States and Canada, exclusive of the Perciformes. Iowa States University Press, Ames. 
Ciocca, D.R., Oesterreich, S., Chamness, G.C., and McGuire, W.L., 1993. Biological and clinical implications of heat shock protein 27, 000 (Hsp27): a review. Journal of the National Cancer Institute. 85: 1558-1570.

Clemento, A.J., Anderson, E.C., Boughton, D., Girman, D., and Garza, J.C., 2009. Population genetic structure and ancestry of Oncorhynchus mykiss populations above and below dams in south-central California. Conservation Genetics. 10:1321-1336.

Currie, R.J., Bennett, W.A., and Beitinger, T.L., 1998. Critical thermal minima and maxima of three freshwater game-fish species acclimated to constant temperatures. Environmental Biology of Fishes. 51(2), 187-200.

Currie, S., and Tufts, B., 1997. Synthesis of stress protein 70 (Hsp 70) in rainbow trout (Oncorhynchus mykiss) red blood cells. J. Exp. Biol. 200, 607-614.

Currie, S., Moyes, C.D., and Tufts, B., 2000. The effect of heat shock and acclimation temperature on hsp 70 and hsp 30 mRNA expression in rainbow trout: in vivo and in vitro comparisons. Journal of Fish Biology. 56, 398-408.

Crivelli, A.J., 2006. Salmo obtusirostris. In: IUCN 2011. IUCN Red List of Threatened Species. Version 2011.2. <www.iucnredlist.org>. Downloaded on 28 May 2012.

Dale, J.W., and vonSchantz, M., 2002. From Genes to Genomes: Concepts and Applications of DNA Technology. John Wiley and Sons, Inc., Publication. Hoboken, NJ USA.

Dunham, K.M., Williamson, D.T., and Joubert, E., 2001. Saudi Arabia. In: Global Survey and Regional Action Plan, Mallon DP, and Kingswood SC, Editors. IUCN, Gland, Switzerland, 55-62.

Eaton, J.G., McCormick, J.H., Goodno, B.E., O'Brien, D.G., Stefany, H.G., Hondzo, M., and Scheller, R.M., 1995. A field information-based system for estimating fish temperature tolerances. Fisheries. 20(4), 10-18.

Edwards, J.B., 1993. Methods in Molecular Biology.Vol. 15. White BA, editor. Humana Press, Totowa, NJ.

Ellis, R.J., 1993. The general concept of molecular chaperones. Phil, Trans. R. Soc. London. $339,257-261$.

Finstad, B., Staurnes, M., and Reite, O.B., 1988. Effect of low temperature on sea-water tolerance in rainbow trout, Salmo gairdneri. Aquaculture. 72, 319-328.

FAO, 2010: Cultured Aquatic Species Information Programme. Oncorhynchus mykiss. FAO Fisheries and Aquaculture Department. <http://www.fao.org/fishery/culturedspecies/Oncorhynchus_mykiss/en>. 
Ford, M.J., 2002. Selection in captivity during supportive breeding may reduce fitness in the wild. Conservation Biology 16, 815-825.

Frankham, R., Briscoe, D.A., and Ballou, J.D., 2002. Introduction to Conservation Genetics. Cambridge University Press, Cambridge/New York.

Gall, G.A.E., Crandell, P.A., 1992. The rainbow trout. Aquaculture 100, 1-9.

Gamperl, A.K., Vijayan, M.M., Boutilier, R.G., 1994. Experimental control of stress hormone levels in fishes: techniques and applications. Rev. Fish Biol. Fish. 9, 215225.

Gjedrem, T., 2000. Genetic improvement of cold-water fish species. Aquaculture Research $31,25-33$.

Groot, C., and Margolis, L., 1991. Pacific Salmon Life Histories. UBC Press. The University of British Columbia. Vancouver, BC.

Heid, C.A., Stevens, J., Livak, K.J., and Williams, P.M., 1996. Real time quantitative PCR. Genome Res. 6, 986-994.

Hendry, A.P., and Stearns, S.C., editors 2003. Evolution illuminated: salmon and their relatives. Oxford University Press, Oxford, UK.

Heredia-Middleton, P., Brunelli, J., Drew, R.E., and Thorgaard, G.H., 2008. Heat shock protein (HSP70) RNA expression differs among rainbow trout (Oncorhynchus mykiss) clonal lines. Comp. Biochem. Physiol. Part B Biochem. Mol. Biol. 149, 552556.

Hofmann, G.E., 1999. Ecologically relevant variation in induction and function of heat shock proteins in marine organisms. Amer. Zool. 39, 889-900.

Iwama, G.K., Pickering, A.D., Sumpter, J.P., and Schreck, C.B. (eds.), 1998. Fish stress and health in aquaculture, pp. 1-34. Cambridge University Press, Cambridge.

Iwama, G.K., McGeer, J.C., and Bernier, N., 1992. The effects of stock and rearing history on the stress response in juvenile coho salmon (Oncorhynchus kisutch). ICES Mar. Sci. Symp. 194, 67- 83.

Iwama, G.K., Vijayan, M.M., and Morgan, J.D., 1999. The stress response in fish. In B. G. Kapoor (ed. of "Felicitation Volume"), Advances in ichthyological research. Oxford and IBH Publishing Co. Ltd. New Delhi. (In Press)

Iwama, G.K., Afonso, L.O.B., Todgham, A., Ackerman, P., and Nakano, K., 2004. Are HSPs suitable for indicating stressed states in fish? The Journal of Experimental Biology. 207, 15-19. 
Kaya, C.M., 1978. Thermal resistance of rainbow trout from a permanently heated stream, and of two hatchery strains. Prog. Fish-Cult. 40, 138-142.

Kiang, J.G., and Tsokos, G.C., 1998. HSPs 70 kDa: Molecular biology, biochemistry and physiology. Pharmacology \& Therapeutics. 80, 183-201.

Kincaid, H.L., Mengel, L.J., and Brimm, S., 2001. National Fish Strain Registry - Trout, species tables of reported strains and broodstocks. United States Fish and Wildlife Service/United States Geological Survey, Washington DC. 165 pp.

La Rivers, I., 1962. Fishes and fisheries of Nevada. Nevada State Fish and Game Comm. 782.

Lewis, J.M., Hori, T.S., Rise, M.L., Walsh, P.J., and Currie, S., 2010. Transcriptome responses to heat stress in the nucleated red blood cells of the rainbow trout (Oncorhynchus mykiss). Physiol. Genomics. 42, 361-373.

Maresca, B., and Lindquist, S., 1991. Heat Shock. Springer-Verlag, Berlin

Mazur, C.F., 1996. The heat shock protein response and physiological stress in aquatic organisms. Doctoral thesis, Univ. British Columbia. 175 pp.

Molony, B., 2001. Environmental requirements and tolerances of Rainbow trout (Oncorhynchus mykiss) and Brown trout (Salmo trutta) with special reference to Western Australia: A review. Department of Fisheries Western Australia. Fisheries Research Report $\mathrm{N}^{\circ} 130$.

Myrick, C.A., and Cech, J.J.Jr., 2000. Temperature influences on California rainbow trout physiological performance. Fish Physiology and Biochemistry. 22(3), 245-254.

Mundy, B.C., 2005. Checklist of the fishes of the Hawaiian Archipelago. Bishop Museum Bulletins in Zoology. Bishop Mus. Bull. Zool. 6, 1-704.

Nature Education, 2011. Scitable by Nature Education. <http://www.nature.com/scitable/topicpage/gene-expression-14121669>

Ojolick, E.J., Cusack, R., Benfey, T.J., and Kerr, S.R., 1995. Survival and growth of all female diploid and triploid rainbow trout (Oncorhynchus mykiss) reared at chronic high temperature. Aquaculture. 131, 177-187.

Palti, Y., Genet, C., Luo, M.C., Charlet, A., Gao, G., Hu, Y., Castano-Sanchez, C., TabetCanale, K., Krieg, F., Yao, J., Vallejo, R.L., and Rexroad III, C.E., 2011. A first generation integrated map of the rainbow trout genome. BMC Genomics. 12, 180.

Porto, M., 2012. Assessing the Thermal Tolerance and Growth Potential at Elevated Temperatures of Three Different Strains of Rainbow Trout (Oncorhynchus mykiss). MS Thesis. West Virginia University, Morgantown, WV. 
Pottinger, T.G., and Pickering, A.D., 1997. Genetic basis to the stress response: Selective breeding for stress-tolerant fish. In GK Iwama, AD Pickering, JR Sumpter, and CB Schreck (eds.), Fish stress and health in aquaculture. 171-193.

Provenzano, M., Rossi, C.R., and Mocillin, S., 2001. The Usefulness of Quantitative RealTime PCR in Immunogenetics. Scientific Communications. ASHI Quarterly; Third Quarter. 89-9.

Rexroad III, C.E., Palti, Y., Gahr, S.A., and Vallejo, R.L., 2008. A second generation genetic map for rainbow trout (Oncorhynchus mykiss). BMC Genetics. 9, 74.

Ritossa, F., 1962. "A new puffing pattern induced by temperature shock and DNP in drosophila". Cellular and Molecular Life Sciences (CMLS). 18 (12), 571-573.

Rodgers, D.W., and Griffiths, J.S., 1983. Effects of elevated thermal regimes on survival of rainbow trout (Salmo gairdneri). J. Great Lakes Res. 9, 421-424.

Ross, L.G., and Ross, B., 1984. Anaesthetic and SedativeTechniques for Fish. Glasgow: Nautical Press.

Lynch, M., and O'Hely, M., 2001. Captive breeding and the genetic fitness of natural populations. Conservation Genetics 2, 363-378.

Lund, S.G., Lund, M.E.A., and Tufts, B.L., 2003. Red blood cell Hsp 70 mRNA and protein as bio-indicators of temperature stress in the brook trout (Salvelinus fontinalis) Can. J. Fish. Aquat. Sci. 60, 460-470.

United States Department of Agriculture, May 2000. Wildlife Habitat Management Institute. Rainbow trout (Oncorhynchus mykiss). Number 13

Vijayan, M.M., Pereira, C., Forsyth, R.B., Kennedy, C.J., and Iwama, G.K., 1997. Handling stress does not affect the expression of the hepatic heat shock protein 70 and conjugation enzymes in rainbow trout treated with pnaphthoflavone. Life Sci. 61, 117-127.

Vrieling, H., Simons, J.W., and vanZeeland, A.A., 1988. Nucleotide sequence determination of point mutations at the mouse HPRT locus using invitro amplification of HPRT mRNA sequences. Mutat Res. 198, 107-113.

Wales, J.H., 1939. General report of investigations on the McCloud River drainage in 1938. Calif. Dept. Fish, Game. 25(4), 272-309.

Wedemeyer, G.A., Barton, B.A., and McLeay, D.J., 1990. Stress and acclimation. In C. B. Schreck and P. B. Moyle (eds.), Methods for fish biology, pp. 451-489. American Fisheries Society, Bethesda, Maryland. 
Wendelaar Bonga, S.E., 1997. The stress response in fish. Physiological Reviews 77, 591625.

Young, J.C., Moarefi, I., and Hartl, F.U., 2001. Hsp90: a specialized but essential proteinfolding tool. J. Cell Biol. 15, 267-274. 


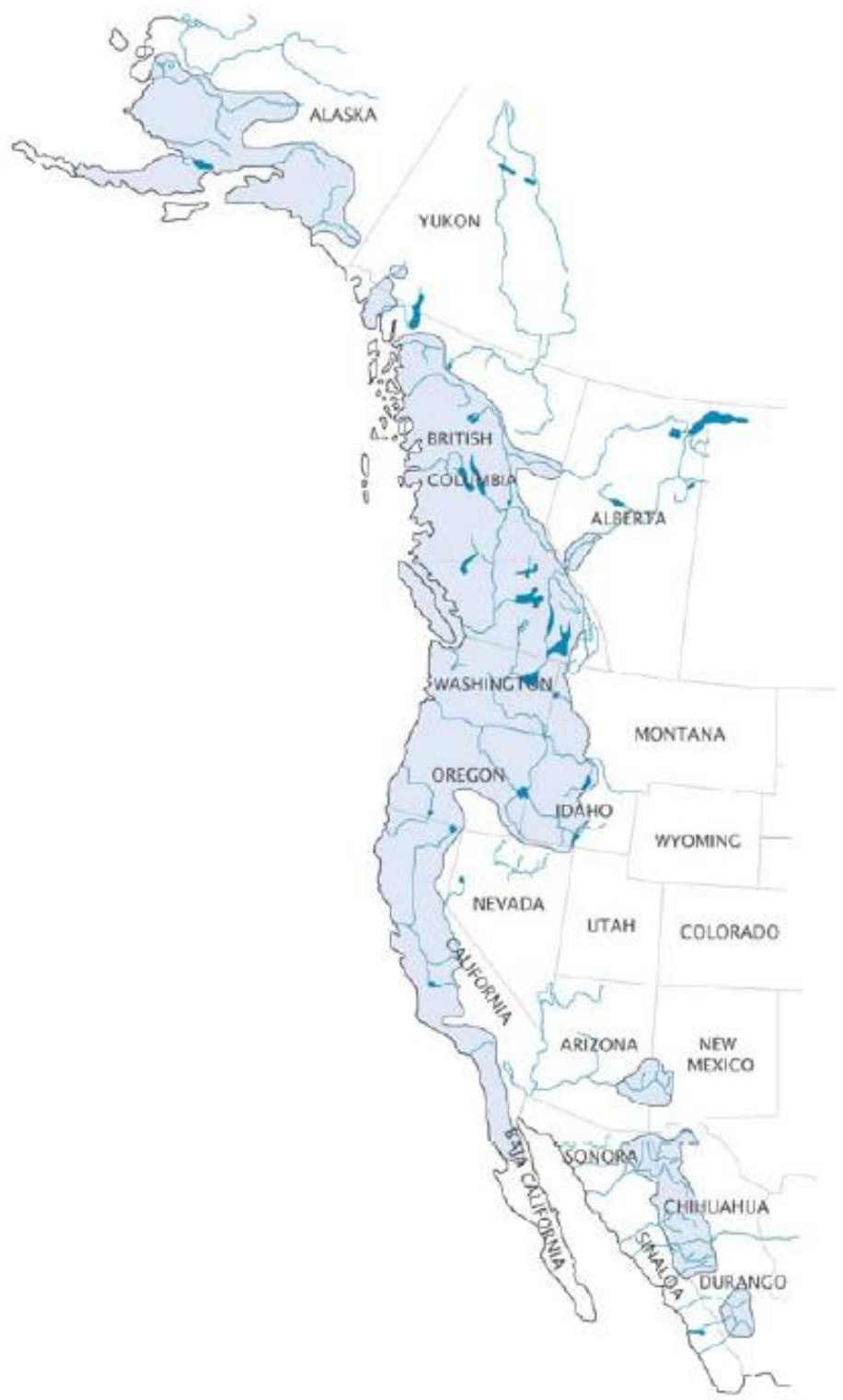

Figure 1.1. Native North American distribution of Oncorhynchus mykiss. Modified from MacCrimmon (1971). 


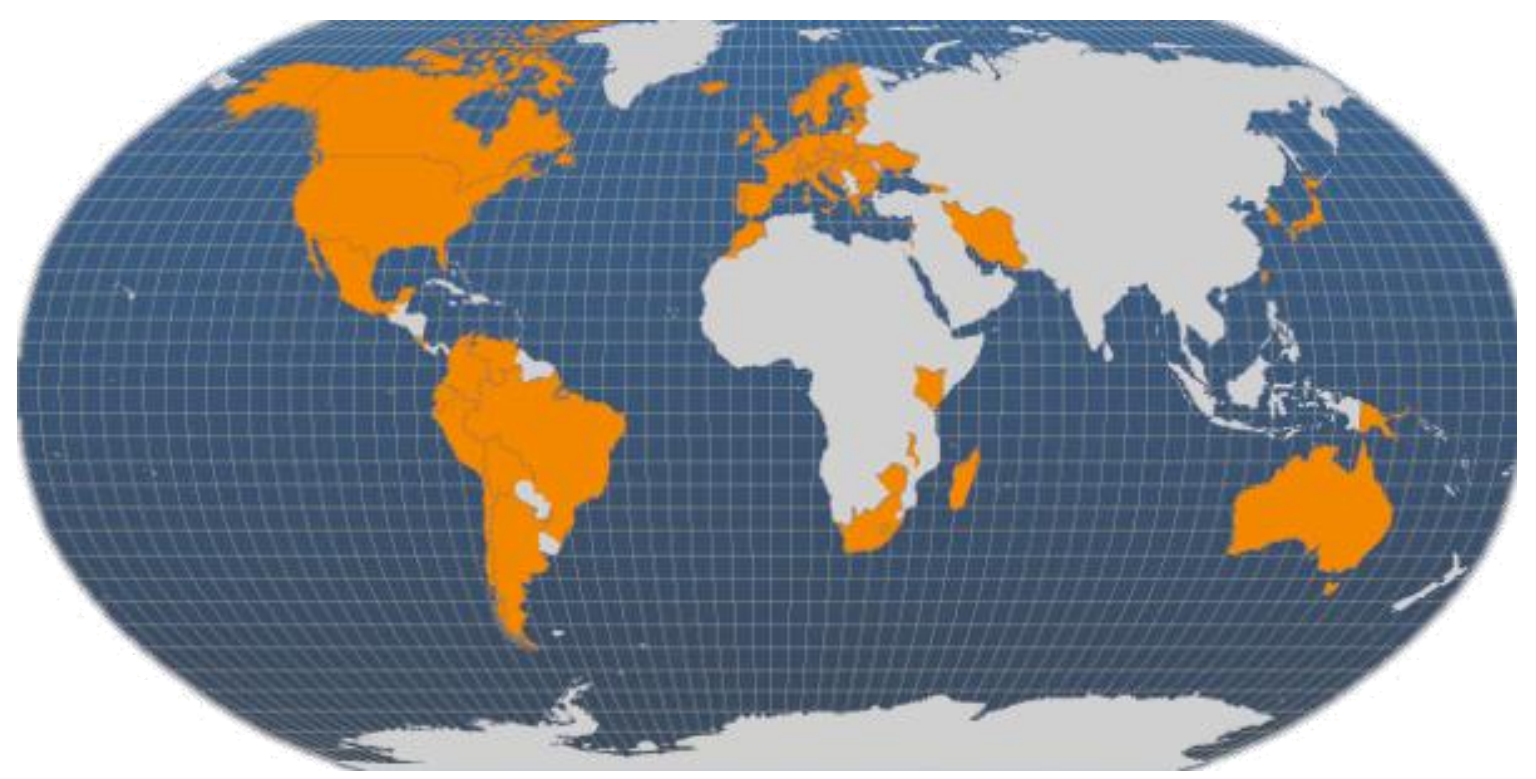

Figure 1.2. Main producer countries (shaded areas) of Oncorhynchus mykiss (FAO Fishery Statistics, 2006) 


\title{
Chapter 2: Comparing the differences in thermal tolerance between the Case Western strain and the Kamloops strain through the expression of HSP70 and HSP90
}

\begin{abstract}
The purpose of this study was to determine if the Case Western strain of rainbow trout (Oncorhynchus mykiss) has a higher thermal tolerance than other strains of rainbow trout, being registered as warm water strain according to the National Fish Strain Registry. This strain has been compared to the Kamloops strain, chosen for its common use in aquaculture facilities. The comparisons were done between the two strains on the relative expression of HSP70 and HSP90. A further analysis assessing the relation between HSPs expression and ages of individuals has been done, and the results were compared between the two strains. The results on the HSP70 and HSP 90 relative expressions confirm that Case Western strain has higher thermal tolerance, highlighting the importance of this strain as a candidate to be cultured in aquaculture facilities as an answer to possible impacts of future climate changes. Earlier studies suggested HSP expression varied with age in rainbow trout, but failed to consider strain-specific differences. Our results show that age-specific HSPs expression is not species-specific in rainbow trout as it differs by strain.
\end{abstract}

\section{Introduction}

As ectothermic organisms, fish are subject to seasonal and daily fluctuations in water temperatures. Rainbow trout (Oncorhynchus mykiss) are cold-water fish of great economic and evolutionary value that prefer temperatures in the range of $11.3{ }^{\circ} \mathrm{C}$ (McCauley et al., 1977) to $19{ }^{\circ} \mathrm{C}$ (Myrick and Cech, 2000). Rainbow trout are poikilothermic, meaning their body temperatures vary with the ambient temperature. Any changes in habitat temperatures will significantly influence metabolism and, hence, growth rate, total production, reproduction seasonality and possibly reproductive efficacy, and susceptibility to diseases and toxins. Being poikilotherms, trout cannot regulate their own body temperature and are completely dependent on favorable habitat being available in order to survive and grow, with 
temperatures above $25{ }^{\circ} \mathrm{C}$ being considered as a potential critical temperature for their survival (Currie et al., 1998; Quinn, 2005). Other studies have found that the upper thermal tolerance for rainbow trout range between $24{ }^{\circ} \mathrm{C}$ (Eaton et al., 1995) and $32{ }^{\circ} \mathrm{C}$ (Myrick and Cech, 2000). Rainbow trout response to these fluctuations in water temperatures must be quick and efficient to avoid harmful health risks.

Stressed fish exhibit a generalized stress response that is characterized by an increase in stress hormones and the consequent changes at the physiological, organismal, and population levels (Barton, 1997; Wendelaar Bonga, 1997). The stress response in fish has a genetic component (Pottinger and Pickering, 1997), thus there are differences in the generalized stress response among different fish species, strains and individuals, differing in tolerance to different stressors (Iwama et al., 1992). The observed stress response is therefore an expression of both genetic and environmental factors such as season, rearing history, and nutritional states (Iwama et al., 1992).

When fish are exposed to stressfully high temperatures, one of the most common features of the cellular stress response is the production of heat shock proteins (HSPs), molecular chaperones in response to stressors that threaten the life of the cells, which is dependent upon the maintenance of protein integrity and functionality (Iwama et al., 1999). A long-term expression of these proteins is disruptive in all organisms, thus HSP response is a quick buffer to minimize the damage to cells when thermal stress happens (Song and Morimoto, 2001), and they have become one of the most well studied indicators of temperature stress and protein damages. Furthermore the HSPs are extremely sensitive and rapid indicators of cellular stress when examined at the mRNA level (Lund et al., 2003).

Basu et al., (2001) investigated the stress response by comparing HSPs' expression between a temperate teleost (O. mykiss; trout) and a tropical finfish (Oreochromis 
mossambicus; tilapia). Tilapia are a stress-tolerant fish species that prefer an optimal temperature range between $22^{\circ}$ and $30^{\circ}$ (Bruton and Boltt, 1975). With their experiment, Basu et al., (2001) demonstrated that the tropical fish were less stressed by high temperatures, and responded with lower levels of HSPs to heat exposure. Consequently, fish that develop a higher thermal tolerance tend to show lower levels of HSPs expression during heat stress tests.

The heat shock protein 70 (HSP70) is the largest HSP family and the most highly conserved of all the heat shock proteins. In addition, in most fish during thermal stress the HSP70 is the most highly induced HSP, with increased levels of HSP70 mRNA and protein (HSP70). The second major family of heat shock proteins is the HSP90. HSP90 is usually active in supporting different components of the cytoskeleton and steroid hormones receptors (Csermely et al., 1998; Pearl and Prodromou, 2000; Young et al., 2001). Currie and Tufts (1997) detected a band corresponding to HSP90 while profiling the HSP70 response in rainbow trout red blood cells, confirming the expression of HSP90 in the nucleus of red blood cells. The expression of HSP90 was studied in a Chinook salmon (Oncorhynchus tshawytscha) embryonic cell line and it was shown to be heat inducible (Palmisano et al., 2000).

In this study we investigate variations in HSP70 and HSP90 expression in response to thermal stress in two strains of rainbow trout: The Case Western strain and The Kamloops strain. According to the National Fish Strain Registry, the Case Western strain is the only registered strain of rainbow trout that originates from a warm water brood stock (Kincaid et $a l ., 2001$ ), and consequently is reputed to tolerate stressful temperature exposure better than other strains of rainbow trout. Dr. Mits Teraguchi at The Case Western Reserve University discovered the strain in the early 1980's, as the byproduct of ecological pond experiments. 
Since the strain was sold in the early 1990's to Laurel Hill Trout Farm, Inc. (Somerset, PA, United States), there has been no selection for thermal tolerance placed on the individuals of this strain. Therefore, the Case Western case study brings up the inquiry of whether this particular strain truly does possess the thermal tolerance it was thought to have, or if it has been lost due to a lack of selective pressure that has not been enforced. The second strain being analyzed in this research is the Kamloops strain, which is popular for its fast growth, vibrant color, and ability to withstand stress. This strain is being studied because it is one of the most widely cultivated and stocked strains of rainbow trout across the United States. In this regard, the goal of this paper is to determine if the HSP70 and HSP90 expression levels are different between these two strains of rainbow trout and thus investigate a molecular basis for higher thermal tolerance of the Case Western strain. This study will be done by quantifying the expression of the genes of interest (GOI) through real-time PCR analysis.

Since most of the inducible heat shock protein genes do not contain introns, the mRNA is rapidly translated into nascent protein within minutes following exposure to a stressor. Fish RBCs are nucleated and are thus capable of heat shock gene transcription and translation (Currie and Tufts, 1997). Currie et al., (2000) showed that the mRNA response for HSP70 in rainbow trout red blood cells (RBCs) was similar in magnitude to that displayed in other tissues during an in vivo heat shock. The ability to easily collect and manipulate blood in non-terminal experiments makes blood an ideal tissue on which to study the cellular temperature stress response on rainbow trout (Lewis et al., 2010). Furthermore the possibility to extract mRNA through repeated sampling allowed us to track the stress response of an individual over time (Iwama et al., 1998).

The experiment investigated the differences of thermal tolerance between the two strains of rainbow trout. As poilkilothems, climate change-induced temperature variations will have a much stronger impact on the spatial distribution of fishing and aquaculture 
activities and on productivity and yields of coldwater species like trout. The effect of climate change on aquaculture could be positive or negative, arising from direct and indirect impacts on the natural resources aquaculture requires, namely water, land, seed, feed and energy (FAO, 2008). As fisheries provide significant feed and seed inputs, the impacts of climate change on them would also affect the productivity and profitability of aquaculture systems. Vulnerability of aquaculture-based communities will stem from their resource dependency and exposure to extreme weather events. Climatic changes could increase physiological stress on cultured stock. This would not only affect productivity but also increase vulnerability to diseases and, in turn, impose higher risks and reduce returns to farmers. Interactions of fisheries and aquaculture subsectors could create other impacts (FAO, 2008). For example, extreme weather events could result in escapes of farmed stock and consequently contribute to reductions in genetic diversity of the wild stock, affecting biodiversity (FAO, 2008).

\section{Materials and Methods}

\section{Experimental Animals and Sampling}

For this experiment 80 individuals of rainbow trout were selected: 40 belonging to the Kamloops strain and 40 belonging to the Case Western strain. The Kamloops strain included 20 six month old individuals $(76.25 \pm 18.30 \mathrm{~g})$ and 20 eighteen month old individuals $(127.64 \pm 23.85 \mathrm{~g})$, both obtained from the Albert Powell State Fish Hatchery, Maryland, United States. The Case Western strain also included 20 six month old $(70.97 \pm 25.25 \mathrm{~g})$ and 20 eighteen month old individuals (134.06 $\pm 27.79 \mathrm{~g})$, both obtained from the Murley Branch Hatchery, Maryland, United States. Once transferred to the Fish Ecophysiology Laboratory at West Virginia University, the rainbow trout were kept in 1,136 liter tanks supplied with aerated flow-through recirculating water at $13{ }^{\circ} \mathrm{C}$, with $\mathrm{pH} 7$ and a $14 \mathrm{~h}$ light-10 $\mathrm{h}$ dark photoperiod. All fish were tagged with passive integrated transponders two months before the beginning of the experiment. Fish were fed to satiation on Silver cup floating pellet (Murray, 
UT, United States) composed of $40 \%$ protein and $10 \%$ fat every other day, and food was withheld from $48 \mathrm{~h}$ prior to blood sampling until the end of the experiment $(\mathrm{t}=72 \mathrm{~h})$, to avoid metabolic influences on the anesthesia and blood samples.

The first step of the experiment consisted of sampling blood from each of the 80 rainbow trout in order to have blood samples in control (pre-thermal stress) conditions at 13 ${ }^{\circ} \mathrm{C}$. Each individual was anesthetized in buffered 3-aminobenzoic acid ethyl ester (MS-222, 40-100 ppm) and $0.4 \mathrm{ml}$ of blood was rapidly sampled from the caudal vein with 1ccheparinized syringes using a 23-gauge needle. The 80 blood samples were collected within one hour from the first fish bled, to ensure all sample processing occurred before the blood cells start to break down, causing RNA damage. Once bled, the fish were returned to water, irrigating their gills until opercular movements were resumed.

After a recovery of 2 weeks, all the individuals in each tank were put under acute heat stress, with an increase of $3{ }^{\circ} \mathrm{C} / \mathrm{h}$ from $13{ }^{\circ} \mathrm{C}$ to $25{ }^{\circ} \mathrm{C}$ (critical temperature). The desired temperature of $25{ }^{\circ} \mathrm{C}$ was reached in $4 \mathrm{~h}$ and trout were maintained at this temperature for 1 hour (heat stress period) and then allowed to gradually return to $13{ }^{\circ} \mathrm{C}$ within 2 hours. Approximately $0.4 \mathrm{ml}$ of blood was sampled immediately after the acute stress $(\mathrm{t}=0 \mathrm{~h})$ from 10 individuals of each strain $(n=20 ; 10$ Case Western, 10 Kamloops), and of these 10 individuals, 5 younger and 5 older rainbow trout were selected. This selection and blood drawing protocol was repeated with 10 fish of each strain at $4 \mathrm{~h}$ post-stress $(\mathrm{t}=4 \mathrm{~h}), 24 \mathrm{~h}$ poststress $(t=24 h)$, and $72 h$ post-stress $(t=72)$ (Table 2.1$)$. These time points were chosen to represent an early, late, and a recovery transcriptional response (Lewis et al., 2010; Quinn et al., 2011). 


\section{Sample processing and RNA extraction}

Within one hour from the blood collection, the samples were centrifuged for 10 minutes at $14,000 \mathrm{rpm}$ at $4{ }^{\circ} \mathrm{C}$ to separate plasma and buffy coat from the RBCs. Total RNA was isolated using the TRIzol® Reagent protocol (Invitrogen, Carlsbad, CA, United States). Once the total RNA was extracted it was diluted in $50 \mu l$ of pure water, and the concentration and purity of each sample were checked with the Thermo Scientific NanoDrop ${ }^{\mathrm{TM}} 1000$ Spectrophotometer (Thermo Fisher Scientific Inc.).

Furthermore, the overall quality of RNA was assessed by electrophoresis on an agarose gel for 10 random samples (Figure 2.1). The diluted total RNA was then treated with DNase I (Ambion Inc., Austin, TX, United States) in order to degrade eventual genomic DNA residuals and incubated for 25 minutes at $37{ }^{\circ} \mathrm{C}$. After the addition of $5 \mu l$ of DNase Inactivation Reagent (DIR) to each sample and the following 2 minute centrifugation at $14,000 \mathrm{rpm}$ at $4{ }^{\circ} \mathrm{C}, 16 \mu l$ of the supernatant were transferred in a new tube. Then, $2 \mu l$ of Oligo dt and $8 \mu l$ of dNTP $(2.5 \mathrm{mM})$ was added to each sample for a total volume of $16 \mu l$, afterwards they were incubated for 5 minutes at $65{ }^{\circ} \mathrm{C}$ and immediately after put on ice to cool down. The cDNA synthesis was completed by adding $8 \mu l$ of $1^{\text {st }}$ Strand Buffer (5xBuffer-reverse), $4 \mu l$ of $0.1 \mathrm{M}$ DDT, and $2 \mu l$ of Super Script III Reverse Transcriptase (Invitrogen) to each sample, following the manufacture's protocol. The samples were then incubated first for 50 minutes at $42{ }^{\circ} \mathrm{C}$, then for 10 minutes at $70{ }^{\circ} \mathrm{C}$. The cDNA was then diluted in pure water 5 times, ending with a final volume of $200 \mu l$ and stored at $-80{ }^{\circ} \mathrm{C}$ until the next analysis.

\section{Real-time PCR}

The cDNA of each sample was used for real-time PCR quantification of HSP70 and HSP90 gene expression. The sequences of HSP70 and HSP90 forward and reverse primers are reported in Table 2.2. Endogenous control rainbow trout B-actin (TC69887) was chosen 
as the housekeeping gene (Table 2.2). Quantitative real-time PCR was performed using iCycler real-time PCR detection system CFX96 (Bio-Rad, Hercules, CA, United States). The $\mathrm{iQ}^{\mathrm{TM}} \mathrm{SYBR}^{\circledR}$ Green Supermix (Bio-Rad, Hercules, CA, United States) was used in $20 \mu \mathrm{l}$ reaction volume containing $2 \mu l$ of primer $(5 \mathrm{mM}), 5 \mu l$ of pure water, $3 \mu l$ of diluted cDNA, and $10 \mu l$ of SYBR ${ }^{\circledR}$ Green Supermix. The cycling parameters for the real-time PCR were 3 minutes at $95{ }^{\circ} \mathrm{C}$, and then the amplification process by 40 cycles of denaturation at $95{ }^{\circ} \mathrm{C}$ for 10 seconds, annealing at $56{ }^{\circ} \mathrm{C}$ for 1 minute. An internal reference (two of the samples under study) was additionally amplified in each plate. Standard curves for the target genes and the reference gene were constructed using 10-fold serial dilutions of cDNA samples pooled from all the samples under study, looking at the expression for the housekeeping gene ( $\beta$-actin). The melting curve analysis was then programmed following the amplifications.

\section{Statistical Analysis}

All data were normalized to enable the comparison among different treatment groups and different strains. The relative gene expression was calculated based on the formula $\mathrm{N} / \mathrm{N}_{\text {lowest }}$, where $\mathrm{N}_{\text {lowest }}$ stands for the lowest normalization value to be compared in the set of data. For each normalization datum (for each individual) for the stressed time points the control normalization value corresponding to the same individual was subtracted in order to have an equal baseline between the two strains. Then for each group of individuals the mean and standard deviation were calculated. The error of calculation was done by dividing each mean by the lowest mean (mean/mean lowest $_{\text {l }}$. Standard deviation relative to the lowest value was calculated multiplying the lowest mean by the standard deviation and dividing it by the mean. Finally the standard error of the mean was calculated (SEM) with the following formula: $\mathrm{SEM}=[\mathrm{STDEV}$ (relative to lowest)]/SQRT (n), $\mathrm{n}$ represents the number of replications (Livak, 1997). 
For each comparison of interest a 2D bar plot was made using the relative expression levels data and SEM. This graph was reproduced to compare gene expression at the different time points between the two strains of rainbow trout. A one-way ANOVA analysis $(\alpha=0.05)$ was performed to compare statistical differences in QRT-PCR results in heat-stressed fish over time and between different strains (Lewis et al., 2010).

\section{Results}

\section{HSP70 expression analysis}

Levels of HSP70 expression for the two control groups were compared (Figure 2.2). For each strain 40 individuals HSP70 expression levels were analyzed. The Case Western strain showed expression for the HSP70 in only 8 individuals out of 40. Instead, the Kamloops strain in the same control environment showed expression for HSP70 in 37 out of 40 individuals. The individuals that did not show the expression of the gene of interest (GOI) had a too low expression to be detected by real-time PCR or there truly was no expression. The 2D bars plot for this comparison (Figure 2.2) shows a higher expression of the heat shock protein 70 for the Kamloops strain in control state $\left(13^{\circ} \mathrm{C}\right)$. The one-way ANOVA performed on the control group (Table 2.3) shows the Case Western strain had a significantly lower HSP70 expression $(\mathrm{p}=0.03142)$ than the Kamloops strain.

The comparison of the relative gene expression of HSP70 from QRT-PCR analysis on the two strains sampled immediately after the heat shock test $(\mathrm{t}=0 \mathrm{~h})$, also shows a higher gene expression for the Kamloops strain (Figure 2.3a). At $\mathrm{t}=0$, HSP70 expression was significantly higher in the Kamloops fish than the Case Western fish $(\mathrm{p}=0.00009)$ (Table 2.4).

At $4 \mathrm{~h}, 24 \mathrm{~h}$, and $72 \mathrm{~h}$ post-stress the quantitative relative expression of HSP70 gene between the two strains was higher in the Kamloops group (Figure $2.3 \mathrm{~b}$, c, and d). At $\mathrm{t}=$ 
24h (Figure $2.3 \mathrm{c}$ ), because of the normalization from the baseline of the control group, the bar plot shows a negative value for the relative expression of HSP70 in Case Western strain. At $4 \mathrm{~h}, 24 \mathrm{~h}$, and $72 \mathrm{~h}$ the differences between strains were not statistically significant.

\section{HSP90 expression analysis}

The levels of the HSP90 gene expression for the two control groups (Figure 2.4) show a higher expression of this gene for the Kamloops strain. Only 12 individuals out of 40 from the Case Western strain showed expression of the GOI. The Kamloops strain showed HSP90 expression in 39 individuals out of 40 . The individuals that did not show the expression of the GOI had a too low expression to be detected by real-time PCR or there truly was no expression. ANOVA indicated HSP90 was significantly higher in the Kamloops than in the Case Western control fish $(\mathrm{p}=0.00303)($ Table 2.5).

Comparisons of relative gene expression of HSP90 at $\mathrm{t}=0, \mathrm{t}=4, \mathrm{t}=24$, and $\mathrm{t}=72$ hours (Figure 2.5) were not significantly different between the two strains. Relative expression was higher in the Kamloops at $\mathrm{t}=0$, then slightly higher in the Case Western fish at $\mathrm{t}=4 \mathrm{~h}$ and $\mathrm{t}=24 \mathrm{~h}$. At $\mathrm{t}=72 \mathrm{~h}$ the relative gene expression of HSP90 gets higher for the Kamloops strain.

In our study, we compared relative gene expression of HSP70 and HSP90 from QRTPCR among strains, but we also examined response within the strains among different aged individuals. Each strain of rainbow trout group was composed of 40 individuals, of which 20 were 6 months old and the other 20 were 18 months old. The individuals' genes of interest expressions were compared in their control state. Case Western strain shows a relatively higher level of both gene expressions for the younger individuals (Figure 2.6), while the Kamloops strain shows a relatively higher level of both gene expressions for the older individuals. 


\section{Discussion}

Fish respond to a stressor by eliciting a generalized physiological stress response, which is characterized by an increase in stress hormones (Iwama et al., 1999; Barton, 2002) and at the cellular level with the increasing synthesis of heat shock proteins (Iwama et al., 1998). This response to stressors has been considered to be adaptive and represents the natural capacity of the fish to respond to stress. Induction of a heat shock response may therefore serve as a sensitive indicator of sublethal cell stress before responses at the organismal level are evident (Sanders, 1990). The magnitude of the response can differ among species, strains, individuals, and even among HSP families (Iwama et al., 2004).

Rainbow trout are an economically important aquaculture species that is cultured all around the world. Climate change-induced temperature variations will likely increase temperature in public waters (FAO, 2008). The majority of the aquaculture facilities use public waters to fill the internal water system, therefore they are directly subjected to an eventual change in water temperatures. This water temperature change will cause progressively more problems from a managerial point of view, as it is always more difficult to control incoming water temperatures. Species with higher temperature tolerance will be more easily cultivated, and over time it is expected that markets for cold water fishes will have an economic decrease (FAO, 2008). Rainbow trout is one of these species that are strictly constrained to cold-water environment. Therefore it would be of extreme importance to detect if there are strains of rainbow trout that are more tolerant to higher temperature and increase the culture of these strains. The Kamloops strain is the most cultivated strain of rainbow trout for its rapid growth and resistance in aquaculture facilities (Kincaid et al., 2001). The Case Western strain instead has been defined as a warm water strain of rainbow trout, even if no studies have been made to confirm it. 
In this regard, the present study provides convincing evidence that the Case Western strain of rainbow trout is less stressed by elevated water temperatures than the popular Kamloops strain. Looking at the results of the HSP70 and HSP90 expression from QRTPCR analysis on the two strains of rainbow trout in a control situation, it is clear that the two strains have different thermal tolerance. Because of that difference in baselines from the control state, in order to detect the true level of expression in stress state for each strain, we did a further normalization relative to the baseline. To be sure that the HSPs differences could be due to general stress a cortisol concentration analysis was performed and showed the same trend for the two strains, and no physiological stress in the control state (Chapter 3). The heat shock proteins are produced when organisms are under heat stress, but even in control situations a small amount of HSPs is produced. The Case Western strain showed a measurable expression for the HSP70 in only 8 individuals out of 40. Instead, the Kamloops strain in the same control environment showed expression for HSP70 in 37 out of 40 individuals. This general situation demonstrates that the Kamloops strain has a lower heat stress tolerance than Case Western, therefore with a higher expression of the HSP70 gene, one of the most highly conserved HSPs, which is most commonly expressed in response to thermal stress (Lewis et al., 2010). The thermal resistance difference between the two strains is confirmed by the significant statistical difference showed by the one-way ANOVA. Regarding the HSP90 expression, the Case Western shows again a lower relative expression than the Kamloops strain. Only 12 individuals out of 40 from the Case Western strain showed expression of the gene of interest (GOI). The Kamloops strain showed a measurable HSP90 expression in 39 individuals out of 40. A study by Porto (2012) confirmed higher thermal tolerance of Case Western strain of rainbow trout, but not genetically. Indeed, Porto (2012) conducted CTM experiments on Case Western, Kamloops and Wytheville strains and found significantly higher CTM in Case Western trout $\left(31.29^{\circ} \mathrm{C}\right), 0.15^{\circ} \mathrm{C}$ higher on average than the Kamloops strain. 
Expression of HSP70 and HSP90 between the strains differed over time following thermal stress. Immediately after the heat stress period $(\mathrm{t}=0 \mathrm{~h})$ the comparison between the two strains shows a higher relative expression of HSP70 for the Kamloops strain. The HSP70 relative expression after 4,24 , and 72 hours from the heat stress test confirmed that the Kamloops strain has a higher expression of the gene of interest. At $t=24 \mathrm{~h}$, Case Western shows a negative relative expression, due to the subtraction of each control individual in order to be able to compare the two strains. This situation means that at $\mathrm{t}=24 \mathrm{~h}$ the Case Western strain shows a lower expression of the HSP70 gene than in the control state. The overall higher expression of the HSP70 happens at the time zero $(\mathrm{t}=0 \mathrm{~h})$, immediately after the heat stress and with a significant difference from the other four time points.

Results of the relative expression of HSP90 between the strains were not as strong as for HSP70. The relative expression of the HSP90 is higher for the Kamloops strain than for the Case Western strain at $\mathrm{t}=0 \mathrm{~h}$, but thereafter the relative expression of HSP90 is similar between the two strains, with slightly higher expression in the Case Western strain at $t=4 \mathrm{~h}$ and $\mathrm{t}=24 \mathrm{~h}$. By $\mathrm{t}=72 \mathrm{~h}$, relative expression of HSP90 was again higher in Kamloops than in Case Western.

The expression of HSP90 and its role as a molecular chaperone are essential for the viability of eukaryotic cells under extended exposure to stress (Lewis et al., 2010). The expression of HSP90 can be stimulated also after psychological stressors such as dominance hierarchies, which develop between individuals within confined environments such as experimental tanks (Iwama et al., 1999). In the present study the tanks were divided per strain, but the individuals of each strain were of two different ages in the same tank (6 months and 18 months old). The last time points of the experiment, after 72 hours from the end of the heat stress $(t=72 h)$ shows a higher relative expression of HSP90 in the Kamloops 
strain (Fig. 2.5d). For both HSPs the Kamloops strain shows an increase in relative expression after 72 hours from the stress, consequently with a slower recovery than the Case Western strain. Salmonid fish form dominance hierarchies in laboratory situations, comparable to those formed in semi-natural or natural situations (Kalleberg, 1958; Bachman, 1984). Currie et al. (2009) showed that the behavioral and physiological stress experienced by juvenile rainbow trout when dominance hierarchies are formed is also reflected at the level of the cellular stress response with the expression of HSPs. The Kamloops strain has a well-known strong behavior, thus it is possible to hypothesize that after $72 \mathrm{~h}$ from the heat stress, the stressful environment generated an indirect psychological stress manifesting a stressful dominance hierarchy (being composed by two sizes of individuals) for the Kamloops group (Currie et al., 2009) with a consequent increase of stress response for some individuals.

By following the relative gene expression across time it is possible to compare expressions reached for both strains at different points of time under the same experimental conditions. The HSP70 expression happens strongly immediately after the end of the heat stress at $\mathrm{t}=0 \mathrm{~h}$, in contrast with Lund et al. (2003) that found the higher peak after 4 hours from the end of the heat stress. Most past studies (Misra et al., 1989; Iwama et al., 1999) report that the increase in HSP70 is the most prominent response to heat shock. The other time points all had lower relative expression, showing a rapid recovery after four hours from the end of the stress test. Our results show that the HSP70 is a very good indicator of thermal stress and protein damage, with an extremely sensitive and rapid indicator of cellular stress when examined at the mRNA level. The comparisons and the significant statistical results with the one-way ANOVA confirmed the difference between the Case Western strain and the Kamloops strain. By this experiment the existence of a different and higher thermal performance of the Case Western strain is inferred, showing a lower expression of the HSP70 
and HSP90 reputed to protect nuclear proteins and possibly transcriptional processes following heat shock (LaThangue, 1984; Collier and Schlesinger, 1986; Biggiogera, et al., 1996; Langer et al., 2003). The HSP90 relative expression over time shows that the vertical line, expressing the relative expression levels, reaches generally lower levels, so the HSP90 expressed is quantitatively lower that the quantities of HSP70 expressed. The HSP90 bar plots (Figure 2.5) show a higher expression of HSP90 after four hours from the end of the heat stress test, in contrast with Sathiyaa et al. (2001) that shows transient elevation of HSP90 mRNA expression over a 24-h period in trout hepatocytes. This may suggest that the expression of HSP90 can be faster in RBCs than other tissues. HSPs have been identified in almost all vertebrate tissues, including the red blood cells of some species (Lund et al., 2003).

From several studies, the critical thermal maxima (CTM) for rainbow trout is approximately $24-26{ }^{\circ} \mathrm{C}$ (Bidgood, 1980). [CTM's are calculated by steadily increasing the temperature of a water body until fish movements become disorganized and/or its sense of balance is upset and normal activity is no longer possible (Currie et al., 1998)]. However, some studies have found lower and higher CTMs depending on thermal history of the fish and life stage. Ojolick et al. (1995) and Benfey (1996) recorded that the CTM for brook trout (Salvelinus fontinalis, a closely related salmonid) was up to $29.8{ }^{\circ} \mathrm{C}$ depending on the age and sex of the fish. Furthermore, Benfey (1996) concluded that younger fish were better able to survive higher temperatures than older fish. Thus, it seems that young fish may be the best able to tolerate extremes of temperature. Furthermore, there are developmental changes in HSP localization in fish tissues under control conditions, with HSP90 distributed differently in mature and juvenile rainbow trout liver (Rendell and Currie, 2005).

In this regard, comparison of the relative gene expression of HSP70 and HSP90 from QRT-PCR analysis between the two ranges of age in each of the two strains of rainbow trout 
red blood cells (RBCs) have been investigated. The individual GOI expressions were compared in their control state because of the bigger sample size and because we detected a difference in expression also in the control state. This comparison is more related to the natural expression of HSPs related to the ages and strains than under stress expression. Each of the two strains (Case Western and Kamloops) used 40 individuals of which 20 were 6 months and 20 were 18 months old. Benfey (1996) found that older individuals of rainbow trout have a higher expression of the heat shock protein than the younger individuals. Rendell et al. (2006) considered both HSP90 and HSP70 expression levels in the heart and stated that juvenile fish show a greater increase in hsp70 after heat shock and mature fish show an enhanced increase in hsp90. This may be a coordinated cellular stress response to ensure a minimum level of protection during thermal stress (Rendell et al., 2006). In this experiment, the younger Case Western shows higher expression of both the GOI than the older individuals, while the Kamloops strain respond in the opposite, with higher expression levels of both the GOI for the older individuals and lower for the younger individuals.

Herredia-Middleton et al. (2008) obtained similar results for the HSP70 gene expression among three different clonal lines of rainbow trout, different from the strains used in this study. Thus, the results obtained with the present study bring forward new elements in favor of different relative expression of HSP70 gene among different strains of rainbow trout. No research has been done on the differences of HSP70 and HSP90 between Case Western and Kamloops strains of rainbow trout. Furthermore, no studies have been done to assess the believed higher thermal tolerance of Case Western strain, registered as warm water strain, looking at the HSP70 and HSP90 relative expressions. Several studies have been done examining the relation between age and HSP expression (Rendell et al., 2006; Currie et al., 2009; Fowler et al., 2009; and Alak et al., 2010), but none of them compared these relations between different strains of rainbow trout. 
In conclusion, the Case Western strain of rainbow trout was confirmed to have better thermal tolerance than the commonly cultured Kamloops strain, with statistically significant differences in heat shock protein expression. Furthermore, susceptibility to thermal stress has been demonstrated to be independent from the life stage of the organism, but more related to the strain of origin within a species. In most cases and for most climate change-related impacts, improved management and better aquaculture practices would be the best and most immediate form of adaptation, providing a sound basis for production that could accommodate potential challenges. Genetic knowledge and management in aquaculture are not as developed as in other husbandries, and will be both a major challenge and an opportunity (FAO, 2008). Examples include genetic improvement for increasing species resistance to higher temperature. The results of this research, which show higher thermal tolerance of the Case Western strain of rainbow trout, could be used to improve aquaculture management. Therefore the utilization of Case Western strain in common aquaculture could help the production of rainbow trout, accommodating possible impacts of climate changes in the future. 


\section{Literature cited}

Alak, G., Ciltas, A., and Erdogan, O., 2010. Hsp-70 Gene Expression Analyses in the Different Ages of Rainbow Trout. Kafkas Univ Vet Fak Derg. Part B 16, 183-187.

Bachman, R.A., 1984. Foraging behavior of free-ranging wild and hatchery brown trout in a stream. Trans. Am. Fish. Soc. 113, 1-32. (doi:10.1577/1548-8659(1984)113, 1:FBOFWA.2.0.CO;2)

Barton, B.A., 1997. Stress in finfish: Past, present, and future - a historical perspective. In Fish stress and health in aquaculture. Edited by Iwama GK, Pickering AD, Sumpter JP, Schreck CB. Cambridge: Cambridge University Press. 1-33

Barton, B.A., 2002. Stress in Fishes: A Diversity of Responses with Particular Reference to Changes in Circulating Corticosteroids. Integ. And Comp. Biol. 42, 517-525.

Basu, N., Nakano, and Iwama, G.K., 2001. The effects of cortisol on Heat Shock Protein 70 levels in two fish species. Gen. and Comp. Endocrinology. 124, 97-105.

Benfey, T.J., 1996. Use of all-female and triploid salmonids for aquaculture in Canada. Bull. Aquaculture Assoc. Can. 2, 6-8.

Biggiogera, M., Tanguay, R.M., Marin, R., Wu, Y., Martin, T.E., and Fakan, S., 1996. Localization of heat shock proteins in mouse male germ cells: an immunoelectron microscopical study. Exp Cell Res 229, 77-85.

Bruton, M.N., and Boltt, R.E., 1975. Aspects of the biology of Tilapia mossambica Peters in a natural freshwater lake (Lake Sibaya, South Africa). J. Fish Biol. 7, 423-445.

Collier, N.C., and Schlesinger, M.J., 1986.The dynamic state of heat shock proteins in chicken embryo fibroblasts. J.Cell Biol. 103, 1495-1507.

Csermely, P., Schnaider, T., Soti, C., Prohaszka, Z., Nardai, G., 1998. The 90-kDa molecular chaperone family: Structure, function, and clinical applications. A comprehensive review. Pharmacol. Ther. 79, 129-168.

Currie, S., Tufts, B.L., 1997. Synthesis of stress protein 70 (Hsp70) in rainbow trout (Oncorhynchus mykiss) red blood cells. J. Exp. Biol. 200, 607-614.

Currie, R.J., Bennett, W.A., Beitinger, T.L., 1998. Critical thermal minima and maxima of three freshwater game-fish species acclimated to constant temperatures. Environmental Biology of Fishes. 51(2), 187-200.

Currie, S., Moyes, C.D., Tufts, B., 2000. The effect of heat shock and acclimation temperature on hsp 70 and hsp 30 mRNA expression in rainbow trout: in vivo and in vitro comparisons. Journal of Fish Biology. 56, 398-408. 
Currie, S., LeBlanc, S., Watters, M.A., and Gilmour, K.M., 2009. Agonistic encounters and cellular angst: social interactions induce heat shock proteins in juvenile salmonid fish. Proc. R. Soc. B. doi: 10.1098/rspb.2009.1562.

Eaton, J.G., McCormick, J.H., Stefan, H.G., Hondzo, M., 1995a. Extreme value analysis of a fish/temperature field database. Ecological Engineering 4, 289-305.

FAO, 2008. CLIMATE CHANGE FOR FISHERIES AND AQUACULTURE. FAO. Rome: FAO.

Fowler, S.L., Hamilton, D., and Currie, S. 2009. A comparison of heat shock response in juvenile and adult rainbow trout (Oncorhynchus mykiss) - implications for increased thermal sensitivity with age. Can. J. Fish. Aquat. Sci. 66, 91-100.

Herredia-Middleton, P., Brunelli, J., Drew, R.E., and Thorgaard, G.H. 2008. Heat shock protein (HSP70) RNA expression differs among rainbow trout (Oncorhynchus mykiss) clonal lines. Comp. Biochem. And Physiol. Part B 149, 552-556.

Iwama, G.K., McGeer, J.C., Bernier, N., 1992. The effects of stock and rearing history on the stress response in juvenile coho salmon (Oncorhynchus kisutch). ICES Mar. Sci. Symp. 194, 67- 83.

Iwama, G.K., Thomas, P.T., Forsyth, R.B., Vijayan, M.M., 1998. Heat shock protein expression in fish. Rev. Fish Biol. Fisher. 8, 35-56.

Iwama, G.K., Vijayan, M.M., Forsyth, R.B., Ackerman, P.A., 1999. Heat shock proteins and physiological stress in fish. Am. Zool. 39, 901-909.

Iwama, G.K., Afonso, L.O.B., Todgham, A., Ackerman, P. and Nakano, K., 2004. Are Hsp suitable for indicating stressed states in fish? Journal of Experimental Biology. 207, 15-19.

Kalleberg, H., 1958. Observations in a stream tank of territoriality and competition in juvenile salmon and trout. Rep. Inst. Freshw. Res. Drottningholm 39, 55-98.

Kincaid, H.L., Mengel, L.J., Brimm, S., 2001. National Fish Strain Registry - Trout, species tables of reported strains and broodstocks. United States Fish and Wildlife Service/United States Geological Survey, Washington DC. 165 pp.

Langer, T., Rosmus, S., Fasold, H., 2003. Intracellular localization of the $90 \mathrm{kDA}$ heat shock protein (HSP90alpha) determined by expression of a EGFP-HSP90 alpha-fusion protein in unstressed and heat stressed 3 T3 cells. Cell. Biol. Int. 27, 47-52.

LaThangue, N.B., Shriver, K., Dawson, C., and Chan,W. L. 1984. Herpes simplex virus infection causes the accumulation of a heat-shock protein. EMBO Journal 3, 267-277.

Lewis, J.M., Hori, T.S., Rise, M.L., Walsh, P.J., Currie, S., 2010. Transcriptome responses to 
heat stress in the nucleated red blood cells of the rainbow trout (Oncorhynchus mykiss). Physiol. Genomics. 42, 361-373.

Livak, K.J., 1997. ABI Prism 7700 sequence detection system. User Bulletin 2. Applied Biosystem. <http://www3.appliedbiosystems.com/cms/groups/mcb_support/document s/generaldocuments/cms_040980.pdf>.

Lund, S., Lund, M.E., Tufts, B.L., 2003. Red blood cell Hsp70 mRNA and protein as bioindicator of temperature stress in the brook trout (Salvelinus fontinalis). Can. J. Fish. Aquat. Sci., 60, 460-470.

McCauley, R.W., Elliott, J.R., and Read, L.A.A., 1977. Influence of acclimation temperature of preferred temperature in the rainbow trout Salmo gairdneri. Trans. Amer. Fish. Soc. 106(4), 362-365.

Misra, S., Zafarullah, M., Price-Haughey, J., and Gedamu, L., 1989. Analysis of stress induced gene expression in fish cell lines exposed to heavy metals and heat shock. Biochim. Biophys. Acta, 1007, 325-333.

Myrick, C.A., and Cech, J.J.Jr., 2000. Temperature influences on California rainbow trout physiological performance. Fish Physiology and Biochemistry 22(3), 245-254.

Ojolick, E.J., Cusack, R., Benfey, T.J., and Kerr, S.R., 1995. Survival and growth of all female diploid and triploid rainbow trout (Oncorhynchus mykiss) reared at chronic high temperature. Aquaculture. 131, 177-187.

Palmisano, A.N., Winton, J.R., Dickhoff, W.W., 2000. Tissue specific induction of hsp90 mRNA and plasma cortisol response in Chinook salmon following heat shock, seawater challenge, and handling challenge. Mar. Biotechnol. 2, 329-338.

Pearl, L.H., Prodromou, C., 2000. Structure and in vivo function of hsp90. Curr. Opin. Struct. Biol. 10, 46-51.

Porto, M., 2012. Assessing the Thermal Tolerance and Growth Potential at Elevated Temperatures of Three Different Strains of Rainbow Trout (Oncorhynchus mykiss). MS Thesis. West Virginia University, Morgantown, WV.

Pottinger, T.G., Pickering, A.D., 1997. Genetic basis to the stress response: Selective breeding for stress-tolerant fish. In GK Iwama, AD Pickering, JR Sumpter, and CB Schreck (eds.), Fish stress and health in aquaculture. 171-193.

Quinn, T., 2005. The Behavior And Ecology Of Pacific Salmon and Trout. University of Washington Press. ISBN: 0295984570.

Quinn, N.L., McGowan, C.R., Cooper, G.A., Koop, B.F., Davidson, W.S., 2011. Ribosomal genes and heat shock proteins as putative markers for chronic, sublethal heat stress in 
Artic charr: applications for aquaculture and wild fish. Physiol. Genomics, 43, 10561064.

Rendell, J.L., and Currie, S., 2005. Intracellular localization of hsp90 is influenced by developmental stage and environmental estrogens in rainbow trout, Oncorhynchus mykiss. Physiol. Biochem. Zool. 78, 937-946.

Rendell, J.L., Fowler, S., Cockshutt, A., and Currie, S. 2006. Development-dependent differences in intracellular localization of stress proteins (hsps) in rainbow trout, Oncorhynchus mykiss, following heat shock. Comp. Biochem. And Physiol. Part D 1, 238-252.

Sanders, B.M. (1990) Stress proteins: potential as multitired biomarkers. In Shugart, L. and McCarthy, J., eds. Biomarkers of Environmental Contamination. Boca Raton, FL: Lewis Publishers. pp. 165-191.

Sathiyaa, R., Campbell, T., and Vijayan M.M., 2001. Cortisol modulates HSP90 mRNA expression in primary cultures of trout hepatocytes. Comparative Biochemistry and Physiology. Part B 129, 679-685.

Song, J., Morimoto, R.I., 2001. Hsp70 chaperone networks: the role of the regulatory cochaperones in coordinating stress responses with cell growth and death. In: Lund, Peter (Ed.), Chapter 6 of Molecular Chaperones in the cell. Oxford Press.

Young, J.C., Moarefi, I., Hartl, F.U., 2001. Hsp90: A specialized but essential proteinfolding tool. J. Cell Biol. 154, 267-273.

Wendelaar Bonga, S.E., 1997. The stress response in fish. Physiol. Rev, 77591-625. 
Table 2.1. Experimental design: time points representing an early and a late transcriptional response for Case Western strain (CW), and Kamloops strain (K).

\begin{tabular}{|c|c|c|c|}
\hline \multicolumn{4}{|c|}{ EXPERIMENTAL DESIGN } \\
\hline \multirow{2}{*}{ Day 1 } & Preliminary Bleeding & Bleed 40 individuals CW & $13 \mathrm{C}$ \\
\cline { 2 - 4 } & Preliminary Bleeding & Bleed 40 individuals K & $13 \mathrm{C}$ \\
\hline Day 2- Day 16 & \multicolumn{2}{|c|}{ Recovery } & $13 \mathrm{C}$ \\
\hline \multirow{2}{*}{ Day 17 } & Heat Stress Test & 80 individuals (CW/K) & $13 \mathrm{C}->25 \mathrm{C}(4 \mathrm{~h})$ \\
\cline { 2 - 4 } & Bleeding at $\mathrm{t}=0 \mathrm{~h}$ & 10 individuals CW & $25 \mathrm{C}(1 \mathrm{~h})$ \\
\hline Day 17 & Bleeding at $\mathrm{t}=0 \mathrm{~h}$ & 10 individuals $\mathrm{K}$ & $25 \mathrm{C}->13 \mathrm{C}$ \\
\hline Day 17 & Bleeding at $\mathrm{t}=4 \mathrm{~h}$ & 10 individuals CW & $13 \mathrm{C}$ \\
\hline Day 17 & Bleeding at $\mathrm{t}=4 \mathrm{~h}$ & 10 individuals $\mathrm{K}$ & $13 \mathrm{C}$ \\
\hline Day 17 & Bleeding at $\mathrm{t}=24 \mathrm{~h}$ & 10 individuals CW & $13 \mathrm{C}$ \\
\hline Day18 & Bleeding at $\mathrm{t}=24 \mathrm{~h}$ & 10 individuals $\mathrm{K}$ & $13 \mathrm{C}$ \\
\hline Day18 & Bleeding at $\mathrm{t}=72 \mathrm{~h}$ & 10 individuals CW & $13 \mathrm{C}$ \\
\hline Day 20 & Bleeding at $\mathrm{t}=72 \mathrm{~h}$ & 10 individuals $\mathrm{K}$ & $13 \mathrm{C}$ \\
\hline Day 20 & & & \\
\hline
\end{tabular}


Table 2.2. Primers used in real-time PCR: HSP70 f/r, HSP90 f/r, and the housekeeping gene BActin $\mathrm{f} / \mathrm{r}$.

\begin{tabular}{|l|l|c|}
\hline $\begin{array}{c}\text { Primer } \\
\text { Name }\end{array}$ & \multicolumn{1}{|c|}{ Sequence (5'-3') } & \multirow{2}{*}{$\begin{array}{c}\text { Amplicon size, } \\
\text { bp }\end{array}$} \\
\hline HSP70 - f & GGGCCAGAAGGTGTCCAATGCAGTC & \multirow{2}{*}{205} \\
\hline HSP70 - r & GCCCCCACCCAGGTCAAAAATGAC & \\
\cline { 1 - 2 } HSP90 - f & CGGGCAGTTCGGTGTGGGTTTCTAC & \multirow{2}{*}{217} \\
\cline { 1 - 2 } HSP90 - r & GACGCGCTTCTCCTCACAGTATTCAA & \multirow{2}{*}{200} \\
\cline { 1 - 2 } BActin - f & CCCATCTACGAGGACTACGC & \\
\hline BActin - r & CCCATCTCCTGCTCAAAGTC & \\
\hline
\end{tabular}


Table 2.3. One-way ANOVA results of the relative gene expression of HSP70 from QRTPCR analysis on the two strains of rainbow trout (O. mykiss) red blood cells (RBCs) sampled as control group. The $\mathrm{p}$-value of 0.03142 shows a significant statistical difference between the two strains of rainbow trout (Case Western vs. Kamloops) in control condition.

\begin{tabular}{|c|c|c|c|c|c|}
\hline ANOVA & & & & & \\
\hline Source & SS & df & MS & F & p-level \\
\hline Trt & 0.09169 & 1 & 0.09169 & 4.80594 & 0.03142 \\
\hline Error & 1.45002 & 76 & 0.01908 & & \\
\hline Total & 1.54171 & 77 & & & \\
\hline
\end{tabular}


Table 2.4. One-way ANOVA results of the relative gene expression of HSP70 from QRTPCR analysis on the two strains of rainbow trout (O. mykiss) red blood cells (RBCs) sampled immediately after the heat shock test $(\mathrm{t}=0 \mathrm{~h})$ that lasts 5 hours. The $\mathrm{p}$-value of 0.00009 shows a significant statistical difference between the two strains of rainbow trout (Case Western vs. Kamloops) at $\mathrm{t}=0 \mathrm{~h}$.

\begin{tabular}{|c|c|c|c|c|c|}
\hline ANOVA & & & & & \\
\hline Source & SS & df & MS & F & p-level \\
\hline Trt & 10.96429 & 1 & 10.96429 & 26.77892 & 0.00009 \\
\hline Error & 6.551 & 16 & 0.40944 & & \\
\hline Total & 17.51528 & 17 & & & \\
\hline
\end{tabular}


Table 2.5. One-way ANOVA results of the relative gene expression of HSP90 from QRTPCR analysis on the two strains of rainbow trout (O. mykiss) red blood cells (RBCs) sampled as control group. The $\mathrm{p}$-value of 0.00303 shows a significant statistical difference between the two strains of rainbow trout (Case Western vs. Kamloops) in control condition.

\begin{tabular}{|c|c|c|c|c|c|}
\hline ANOVA & & & & & \\
\hline Source & SS & df & MS & F & p-level \\
\hline Trt & 0.59228 & 1 & 0.59228 & 9.3805 & 0.00303 \\
\hline Error & 4.79863 & 76 & 0.06314 & & \\
\hline Total & 5.39091 & 77 & & & \\
\hline
\end{tabular}




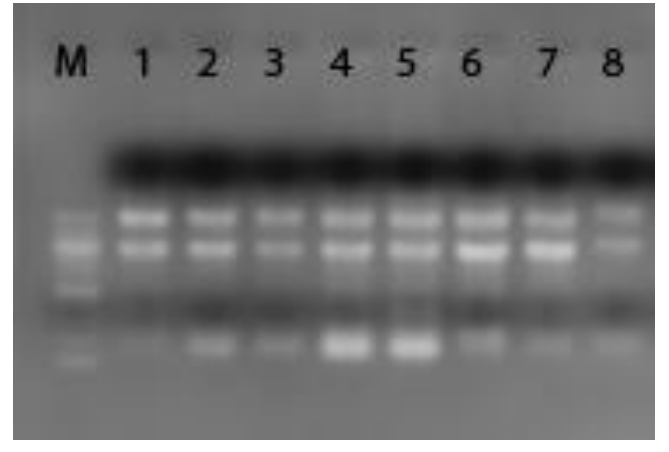

Figure 2.1. Agarose gel electrophoresis of RNA extracted from 8 samples. 


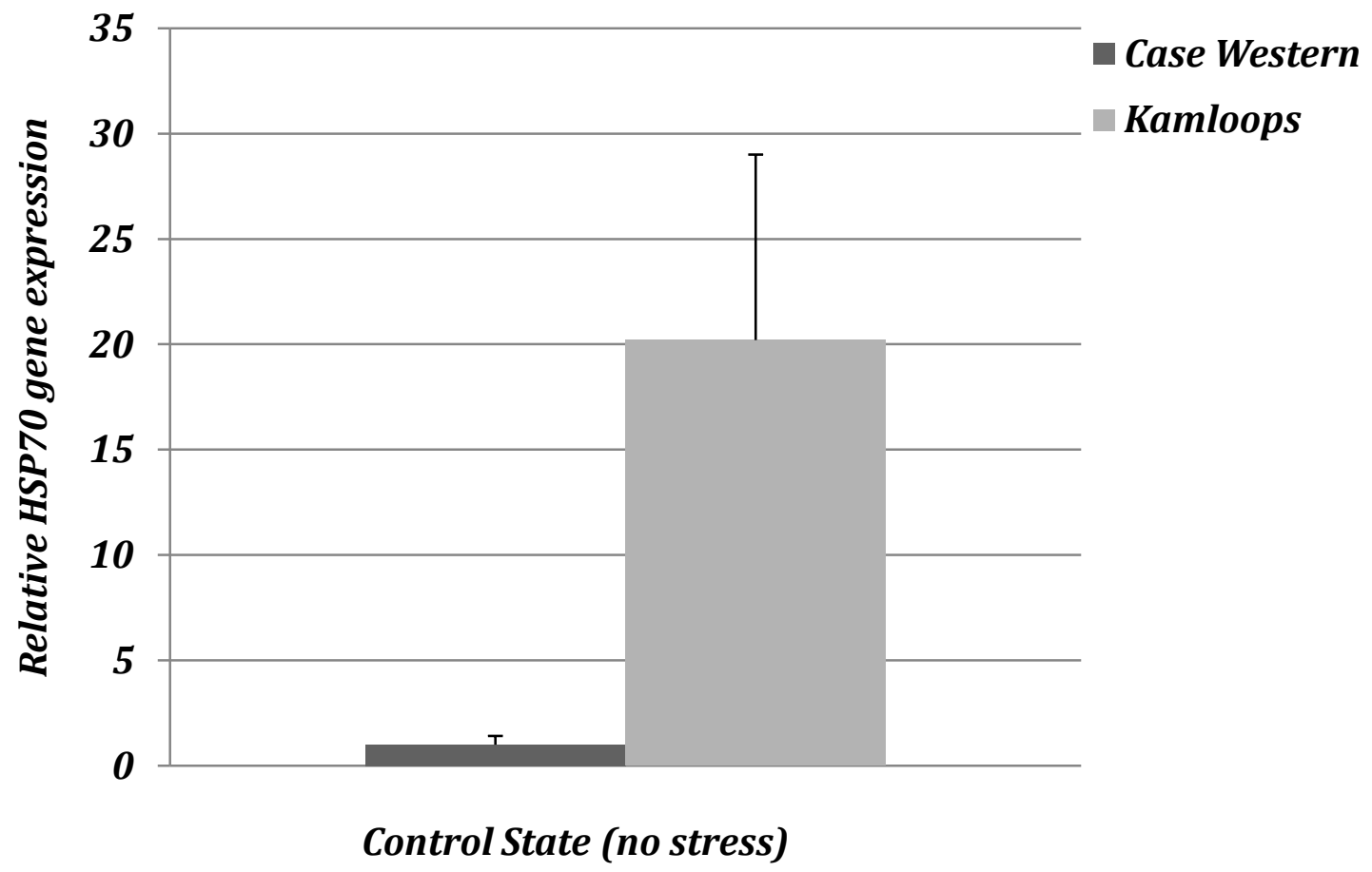

Figure 2.2. Comparison of the relative gene expression of HSP70 from QRT-PCR analysis on the two strains of rainbow trout (O. mykiss) red blood cells (RBCs) sampled as control two weeks before the heat shock test. Vertical bars represent the relative gene expression values, and lines represent traces of individual response based on 40 individuals per strain. The error bars represent the standard error of the mean (SEM). The dark grey column represents the Case Western control group, and the light grey column represents the Kamloops control group. 

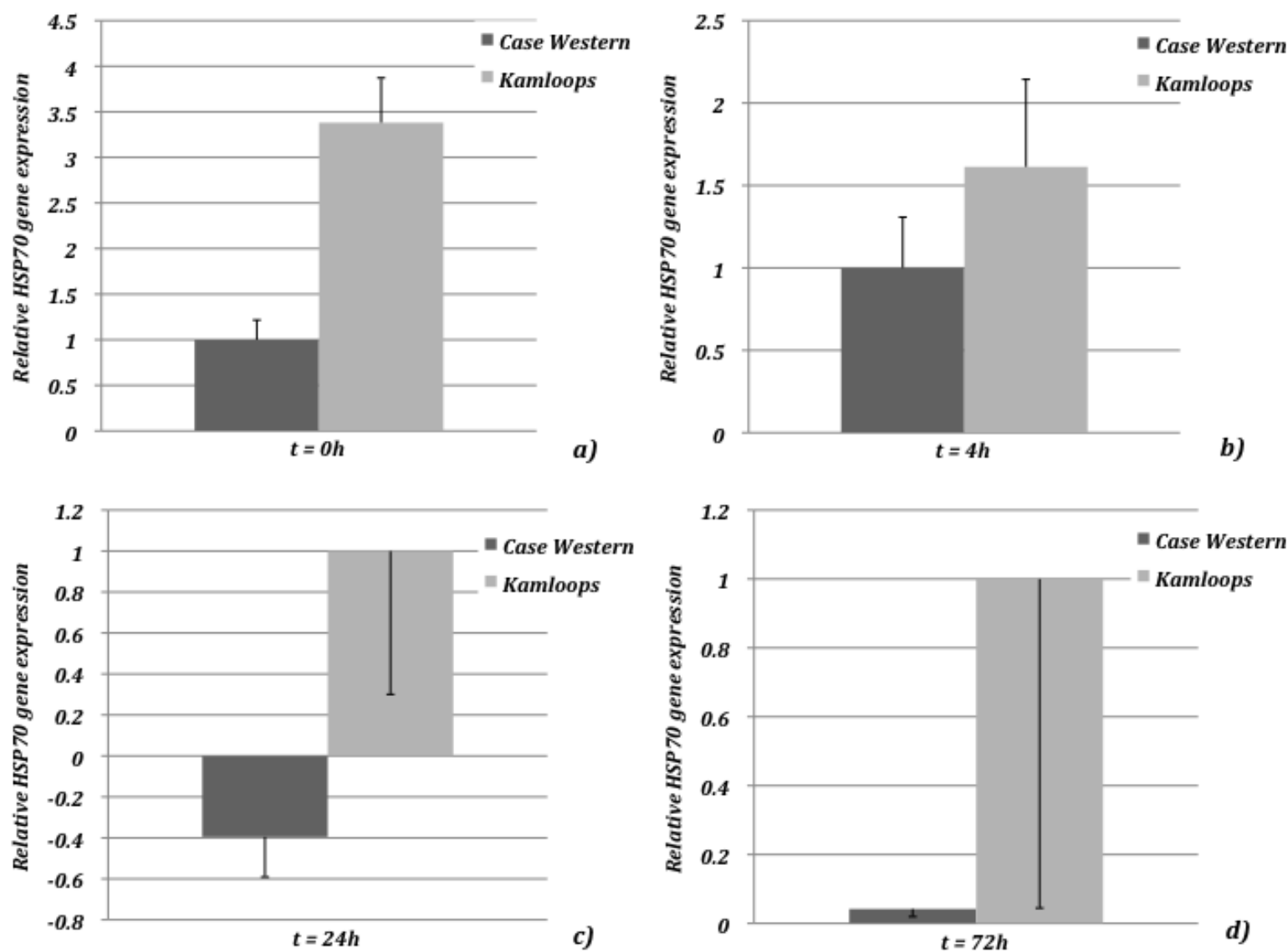

Figure 2.3. Comparison of the relative gene expression of HSP70 from QRT-PCR analysis on the two strains of rainbow trout (O. mykiss) red blood cells (RBCs): a) sampled immediately after the heat shock test $(\mathrm{t}=0 \mathrm{~h})$ that lasts 5 hours; $\mathrm{b})$ after 4 hours from the end of the heat stress test $(t=4 h) ; c)$ after 24 hours from the end of the heat stress test $(t=24 h)$; and d) after 72 hours from the end of the heat stress test $(t=72 \mathrm{~h})$. Vertical bars represent the relative gene expression values, and lines represent traces of individual response on 10 individuals per strain. The error bars represent the standard error of the mean (SEM). The dark grey column represents the Case Western strain, and the light grey column represents the Kamloops strain. 


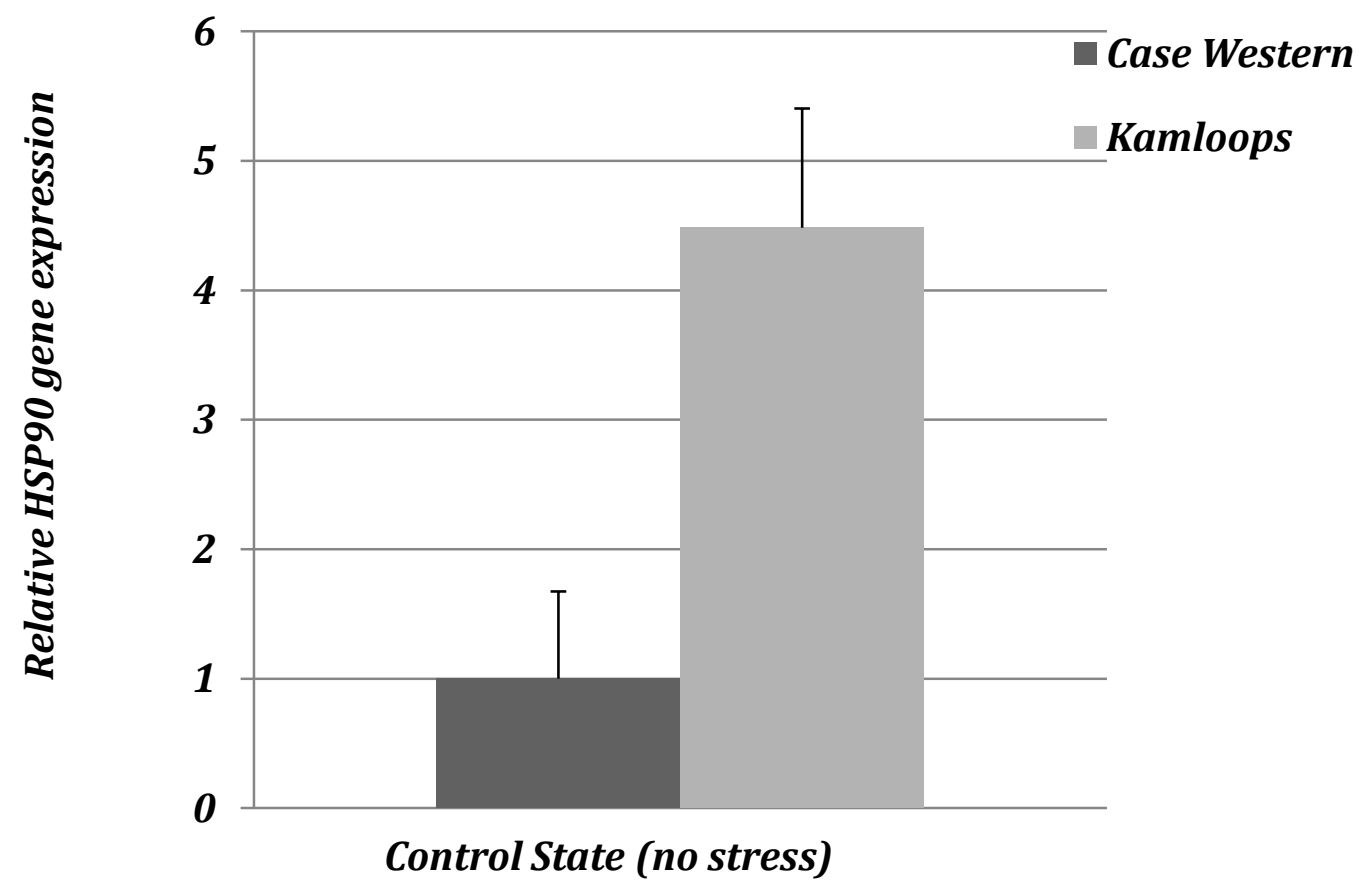

Figure 2.4. Comparison of the relative gene expression of HSP90 from QRT-PCR analysis on the two strains of rainbow trout (O. mykiss) red blood cells (RBCs) sampled as control two weeks before the heat shock test. Vertical bars represent the relative gene expression values, and lines represent traces of individual response based on 40 individuals per strain. The error bars represent the standard error of the mean (SEM). The dark grey column represents the Case Western control group, and the light grey column represents the Kamloops control group. 

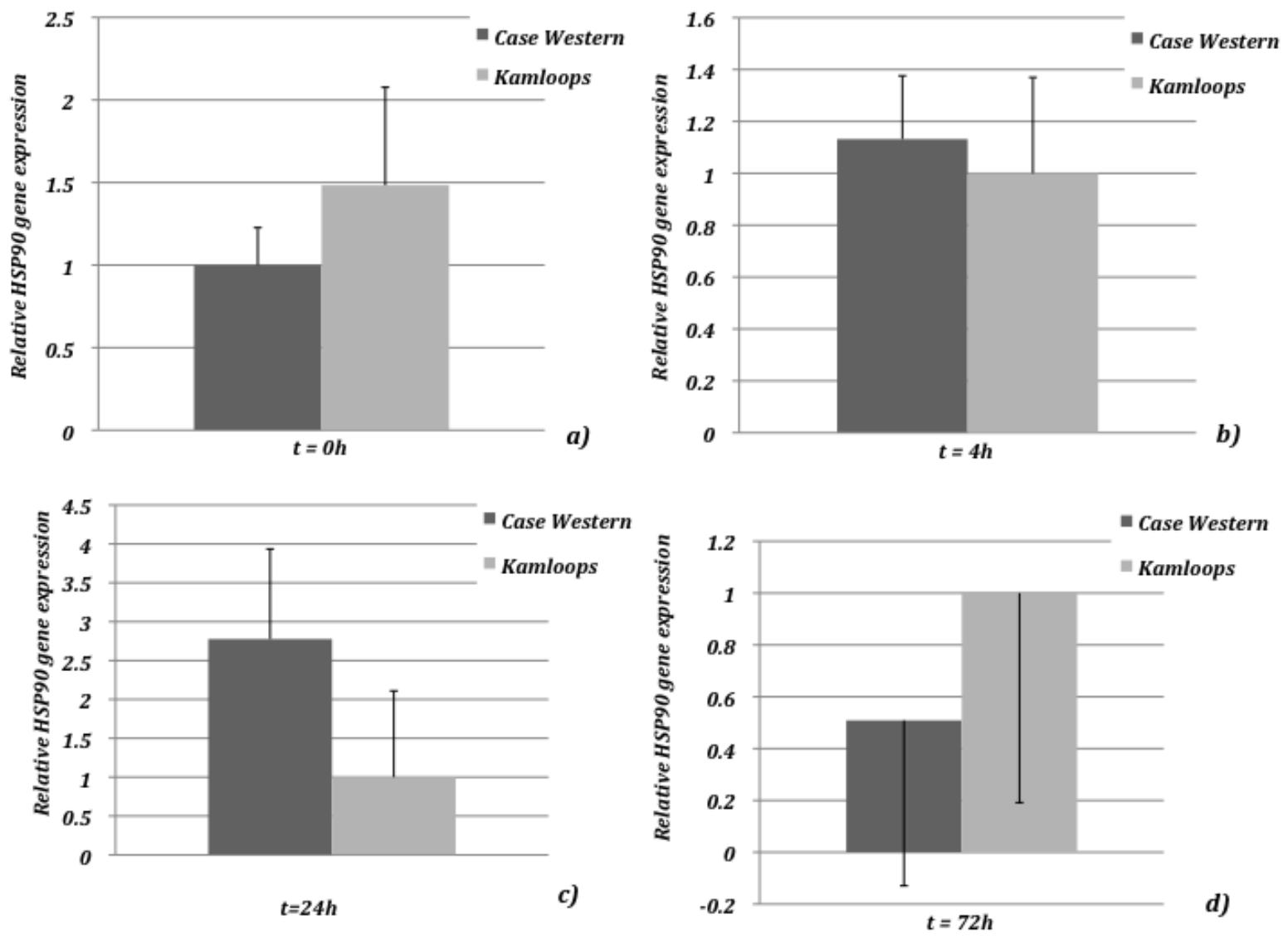

Figure 2.5. Comparison of the relative gene expression of HSP90 from QRT-PCR analysis on the two strains of rainbow trout (O. mykiss) red blood cells (RBCs): a) sampled immediately after the heat shock test $(\mathrm{t}=0 \mathrm{~h})$ that lasts 5 hours; $\mathrm{b})$ after 4 hours from the end of the heat stress test $(t=4 h) ; c)$ after 24 hours from the end of the heat stress test $(t=24 \mathrm{~h})$; and $\mathrm{d}$ ) after 72 hours from the end of the heat stress test $(t=72 \mathrm{~h})$. Vertical bars represent the relative gene expression values, and lines represent traces of individual response on 10 individuals per strain. The error bars represent the standard error of the mean (SEM). The dark grey column represents the Case Western strain, and the light grey column represents the Kamloops strain. 

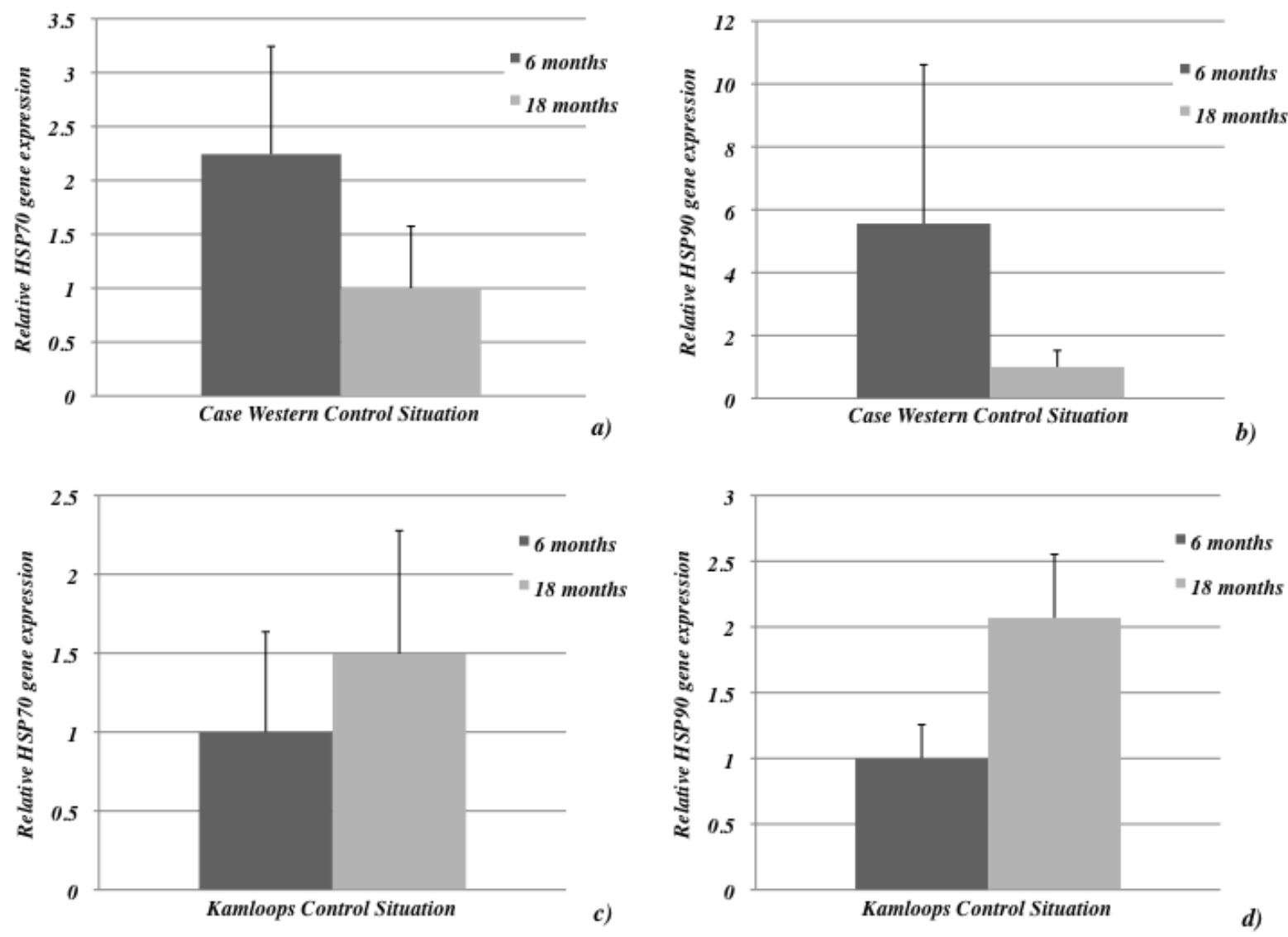

Figure 2.6. Comparison of the relative gene expression of HSP70 and HSP90 from QRTPCR analysis between the two ranges of age in each of the two strains of rainbow trout $(O$. mykiss) red blood cells (RBCs). The individuals GOI expressions were compared in their control state. Each strain comprehended 40 individuals of which 20 had 6 months and 201 year old. Vertical bars represent the relative gene expression values, and lines represent traces of individual response. The error bars represent the standard error of the mean (SEM). The dark grey column represents individuals of 6 months old, and the light grey column represents individuals of 18 months. 


\title{
Chapter 3: Cellular and physiological responses to heat stress in two strains of rainbow trout (Oncorhynchus mykiss): Case Western and Kamloops strains
}

\begin{abstract}
Two different strains of rainbow trout (Oncorhynchus mykiss) were used for the present study: Case Western strain and Kamloops strain. The purpose of this study was to investigate if the plasma cortisol level production in a control and a stressed state varies with the strain or is species-specific. Furthermore, this study examined the relations of cortisol levels with the relative expression of HSP70 and HSP90 genes, and how these three factors influence the variance among different treatment groups. The results show that the plasma cortisol levels before and after thermal stress do not differ among strains, and that the physiological response to heat stress is species-specific. The results on the HSP70 and HSP 90 relative expressions confirm that the Case Western strain has higher thermal tolerance, highlighting the importance of this strain as a candidate to be cultured in aquaculture facilities as an answer to possible impacts of future climate change. The variable that has the largest influence on the variance expressed among groups came from the HSP90 gene. We found the stressed Kamloops was the most diverse group, with less thermal tolerance, influenced mostly by the weight of the HSP90 on the total variance.
\end{abstract}

\section{Introduction}

Biological and abiotic stressors can invoke several biochemical and physiological changes in fish (Wendelaar Bonga, 1997). At the organismal level, these changes are mediated by the neuroendocrine system and characterized by increased concentrations of circulating stress hormones, such as cortisol (Sumpter, 1997; Mommsen et al., 1999). Furthermore, generalized stress responses at the cellular level have been observed following exposure to stressful situations in nearly all organisms (Welch, 1993; Feder and Hofmann, 1999). In poikilotherms exposed to stressfully high temperatures, the principal characteristic 
of these cellular stress responses is the induction of heat shock proteins (HSPs) (Welch, 1993). Constitutive HSPs have several functions within a cell related to protein assembly, folding, translocation, and denaturation (Pratt, 1993). In addition, many HSPs have been induced in fish exposed to various stressors, indicating a protective role for HSPs during times of stress (Iwama et al., 1999). The underlying functions of these two levels of stress responses are highly conserved throughout evolution across a wide variety of organisms, ubiquitous in nature, and predictable during times of rest and stress (Barton and Iwama, 1991; Wendelaar Bonga, 1997; Feder and Hofmann, 1999; Iwama et al., 1999).

The physiological stress response has been classified into a primary, secondary, and tertiary response for several years (Barton, 2002), but Vijiayan et al. (2010) added a quaternary and quinary response to the physiological stress. The primary stress response consists of rapid neural responses that occur in the autonomic nervous system, including the release of catecholamines, norepinephrine, and acetylcholine. The secondary stress response consists of the release of endocrine catcholamines from the chromaffin cells in the interrenal tissue into the circulation, stimulated by the autonomic nervous system. The tertiary stress response is associated with the hypothalamus stimulation by the steroidogenic cells of the interrenal tissue to synthesize increasing plasma cortisol concentrations and release it into circulation within minutes from the exposure to the stressor (around 15 minutes). The increased release of cortisol from the steroidogenic cell components of the interrenal tissue in the head kidney occurs in response to stimulation by several pituitary hormones (adrenocorticotropin [ACTH], a-melanocyte stimulating hormone [aMSH], and $\beta$-endorphin), of which ACTH appears to be the most potent agonist (Wendelaar Bonga, 1997; Iwama et al., 2006; Aluru and Vijayan, 2008). The tertiary response describes the elevation of blood cortisol levels by several folds within minutes, and the cortisol elevation lasts for several hours in response to a stress signal (Gamperl and Boutilier, 1994; Iwama et al., 2006). The 
quaternary stress response refers to aspects of whole-animal performance such as changes in growth, condition, disease resistance, metabolic responses, behavior, and ultimately survival (Wedemeyer and McLeay, 1981; Wedemeyer et al., 1990; Vijiayan et al., 2010). In extreme situations of exposure to stressors, individuals may have a fifth series of response events seen at a population level resulting in changes in reproductive parameters, growth potential, immune protective ability, all of which are probably related to elevated plasma glucocorticoid levels (Gamperl and Boutilier, 1994; Mommsen et al., 1999; Davies, 2010; Leatherland et al., 2010; Schreck, 2010; Vijayan et al., 2010; Pankhurst, 2011). As indicated above, long-term stress exposure (high levels of cortisol in the circulation system) can cause social and psychological events, some of which are associated with altered central nerve system function (discussed below) (Seckl, 2004; Watts, 2005; Weinstock, 2005; Tasker et al., 2006; Revollo and Cidlowski, 2009). Cortisol synthesis and release from interrenal cells has a lag time of several minutes, unlike chromaffin cells, and, therefore, proper sampling protocol can allow measurement of resting levels of this hormone in fish (Wedemeyer et al., 1990; Gamperl et al., 1994). As a result, the circulating level of cortisol is commonly used as an indicator of the degree of stress experienced by fish (Barton and Iwama, 1991; Wendelaar Bonga, 1997).

The stress response in fish has a genetic component (Pottinger and Pickering, 1997). Therefore there are differences in stress response among different fish species, stocks and strains of the same species. The observed stress response is the combined expression of environmental and genetic factors (Iwama et al., 1992). The cellular stress response, especially HSP70 and HSP90, act as molecular chaperones to facilitate in the assembly and folding of denatured proteins, and aid in the translocation of proteins between cellular organelles. Many studies have shown the influence of high levels of cortisol on the 
expression of the HSPs (Basu et al., 2001; Sathiyaa et al., 2001; Feldhaus, 2008; Celi et al., 2012).

This study investigated the validity of the supposed higher thermal tolerance of Case Western strain of rainbow trout, comparing it with a commonly reared strain, the Kamloops strain. The Case Western strain is the only registered strain of rainbow trout that originates from a warm water brood stock according to the National Fish Strain Registry (Kincaid et al., 2001), and consequently is reputed to tolerate stressful temperature exposure better than other strains of rainbow trout. Dr. Mits Teraguchi at the Case Western Reserve University discovered the strain in the early 1980's, as the byproduct of ecological pond experiments. Since the strain was sold in the early 1990's to Laurel Hill Trout Farm, Inc. (Somerset, PA, United States), there has been only one study related to thermal tolerance done on the individuals of this strain, and none involving physiological stress responses. Porto (2012) conducted laboratory experiments and determined that the Case Western strain had a $0.15{ }^{\circ} \mathrm{C}$ higher critical thermal maximum (CTM) than the Kamloops strain. Such a small difference in CTM among these strains brings up the question of whether this particular strain truly does possess the thermal tolerance it was thought to have, or if it has been lost due to a lack of selective pressure. The goal of this experiment is to investigate if the blood cortisol levels produced in a control and in a stressed state varies with the strain or is species-specific. This study also examines the relations of cortisol levels with HSP70 and HSP90 expression, and how these three factors influence the variance among different treatment groups.

\section{Materials and Methods}

\section{Experimental Animals and Sampling}

For this experiment, rainbow trout were raised in the same conditions and allowed to acclimate once they were transferred to the Fish Ecophysiology Laboratory at West Virginia University (Morgantown, WV, United States). The rainbow trout were kept in 1,136 liter 
tanks supplied with aerated flow-through recirculating water at $13{ }^{\circ} \mathrm{C}$, with $\mathrm{pH} 7$ and a $14 \mathrm{~h}$ light-10 h dark photoperiod. For this experiment 10 individuals of the Kamloops strain $(108.54 \pm 41.09 \mathrm{~g})$ were obtained from Albert Powell State Fish Hatchery, MD, United States. Another 10 individuals of Case Western strain $(114.03 \pm 49.07 \mathrm{~g})$ were obtained from Murley Branch Hatchery, MD, United States. All fish were tagged with passive integrated transponders two months before the beginning of the experiment. Fish were fed to satiation on Silver cup floating pellet (Murray, UT, United States) composed of $40 \%$ protein and 10\% fat every other day, and food was withheld $48 \mathrm{~h}$ prior to blood sampling until the end of the heat stress experiment, to avoid metabolic influences on the anesthesia and blood samples.

Throughout the experiment the two strains of rainbow trout were kept separate in two different tanks (Table 3.1, experiment design). The first step of the experiment consisted of sampling blood from each of the 20 individuals of rainbow trout in order to have blood samples in control conditions at $13{ }^{\circ} \mathrm{C}$ (Control State, CS). Each individual was anesthetized in a buffered 3-aminobenzoic acid ethyl ester (MS-222, 40-100 ppm) and 0.4 ml of blood was rapidly sampled from the caudal vein with 1cc ammonium heparinized syringes using a 23gauge needle. Once bled, the fish were returned to the water, irrigating their gills until opercular movements were resumed.

After a recovery period of 2 weeks, rainbow trout $(\mathrm{n}=20)$ were subjected to an in vivo heat shock of $3{ }^{\circ} \mathrm{C} /$ hour, beginning at $13^{\circ} \mathrm{C}$ (ambient temperature) increasing to $25{ }^{\circ} \mathrm{C}$ (in 4 hours), where the water flux was stopped and oxygenation augmented. Fish were maintained at this elevated temperature of $25{ }^{\circ} \mathrm{C}$ for one hour (heat stress period) and then the water was allowed to cool back to ambient temperature. Approximately $0.4 \mathrm{ml}$ of blood was sampled immediately after the end of the acute stress from all the 20 individuals of rainbow trout (Stressed State, SS), representing an early transcriptional response (Lewis et al., 2010; Quinn 
et al., 2011). The blood samples were used to analyze: Cortisol levels, HSP70 relative expressions, and HSP90 relative expressions of the two strains of rainbow trout. Blood samples were kept on ice for less than $1 \mathrm{~h}$ before centrifugation for 20 minutes at 14,000 rpm at $4{ }^{\circ} \mathrm{C}$. Separated plasma was transferred to Eppendorf tubes and stored at $-80{ }^{\circ} \mathrm{C}$ until analyzed for plasma cortisol levels. This analysis was determined using a Fish Cortisol Immunoassay Elisa kit (NovaTeinBio, Cambridge, MA, United States). The remaining buffy coat was poured from the tubes, leaving only red blood cells (RBCs) in the tubes. RBCs were then processed immediately for the extraction of mRNA, in order to analyze the relative expression of HSPs genes through quantitative real-time PCR.

\section{Sample processing for Cortisol measurements}

The coated well immunoenzymatic assay for the quantitative measurement of cortisol utilizes a multiclonal anti-Cortisol antibody and a Cortisol-HRP conjugate. One blank (empty well) and six standards $(100 \mu \mathrm{l})$ were added to the plate in duplicates, the standards had the following concentrations: $0 \mathrm{ng} / \mathrm{ml}, 2.5 \mathrm{ng} / \mathrm{ml}, 5 \mathrm{ng} / \mathrm{ml}, 10 \mathrm{ng} / \mathrm{ml}, 25 \mathrm{ng} / \mathrm{ml}$, and $50 \mathrm{ng} / \mathrm{ml}$. The samples were previously diluted with a ratio of $1: 1$ and then $100 \mu$ l of each diluted sample were added to the appropriate well of the antibody pre-coated Microtiter Plate in duplicates. $50 \mu 1$ of conjugate were added to each well, and after being mixed well the plate was covered and incubated at $37{ }^{\circ} \mathrm{C}$ for one hour. After the incubation period, the wells were decanted and washed five times with a wash solution (1x) from the Elisa kit to remove unbound substance. The following step consisted of adding $50 \mu 1$ of the kit's chromogenic Substrate A and $50 \mu 1$ of chromogenic Substrate B (substrate for HRP enzyme) to each well, to ensure the same adding time difference. The product of the enzyme-substrate reaction forms a blue colored complex. The plate was then covered and incubated for 10 minutes at $25{ }^{\circ} \mathrm{C}$ away from sunlight, because the chromogenic Substrate B is very light sensitive. Finally, $50 \mu 1$ of stop 
solution were added to each well, in order to stop the reaction process and the solutions until the wells turned yellow. The intensity of the color has been measured spectrophotometrically at $450 \mathrm{~nm}$ in a common microplate reader immediately after the addition of the stop solution. The intensity of the color is inversely proportional to the cortisol concentration since cortisol from samples and cortisol-HRP conjugate compete for the anti-cortisol antibody binding site. Since the number of sites is limited, as more sites are occupied by cortisol from the sample, fewer sites are left to bind cortisol-HRP conjugate.

\section{Sample processing for HSP70 and HSP90 genes relative expressions measurements}

Total RNA was isolated using the TRIzol® Reagent protocol (Invitrogen, Carlsbad, CA, United States). Once the total RNA was extracted it was diluted in $50 \mu l$ of pure water, and the concentration and purity of each sample were checked with the Thermo Scientific NanoDrop ${ }^{\mathrm{TM}} 1000$ Spectrophotometer (Thermo Fisher Scientific Inc.). Furthermore, the overall quality of RNA was assessed by electrophoresis on an agarose gel for 10 random samples (Figure 3.1). The diluted total RNA was then treated with DNase I (Ambion Inc., Austin, TX, United States) and incubated for 25 minutes at $37^{\circ} \mathrm{C} .16 \mu l$ of the supernatant was transferred to a new tube after the addition of $5 \mu l$ of DNase Inactivation Reagent (DIR) to each sample and then centrifuged for 2 minutes at 14,000 rpm at $4{ }^{\circ} \mathrm{C} .2 \mu \mathrm{l}$ of Oligo dt and $8 \mu l$ of dNTP $(2.5 \mathrm{mM})$ were then added to each sample, incubated for 5 minutes at $65{ }^{\circ} \mathrm{C}$ and immediately put on ice to cool down. The cDNA synthesis was completed by adding $8 \mu l$

of $1^{\text {st }}$ Strand Buffer (5xBuffer-reverse), $4 \mu l$ of $0.1 \mathrm{M}$ DDT, and $2 \mu l$ of Super Script III Reverse Transcriptase (Invitrogen), to each sample, following the manufacturer's protocol. The samples were then incubated first for 50 minutes at $42{ }^{\circ} \mathrm{C}$, then for 10 minutes at $70{ }^{\circ} \mathrm{C}$. The cDNA was then diluted in pure water 5 times, ending with a final volume of 200ul and stored at $-80{ }^{\circ} \mathrm{C}$ until the next analysis. 
The cDNA of each sample was used for real-time PCR quantification of HSP70 and HSP90 gene expression. The sequences of HSP70 and HSP90 primers forward and reverse and the rainbow trout $B$-actin (TC69887) chosen as endogenous control are reported in Table 3.2. Quantitative real-time PCR was performed using iCycler real-time PCR detection system CFX96 (Bio-Rad, Hercules, CA, United States). The iQ ${ }^{\mathrm{TM}} \mathrm{SYBR}^{\circledR}$ Green Supermix (BioRad, Hercules, CA, United States) was used in $20 \mu l$ reaction volume containing $2 \mu l$ of primer $(5 \mathrm{mM}), 5 \mathrm{ul}$ of pure water, $3 \mu l$ of diluted cDNA, and $10 \mu l$ of $\mathrm{SYBR}^{\circledR}$ Green Supermix. The cycling parameters for the real-time PCR were 3 minutes at $95{ }^{\circ} \mathrm{C}$, and then the amplification process by 40 cycles of denaturation at $95{ }^{\circ} \mathrm{C}$ for 10 seconds, annealing at $56{ }^{\circ} \mathrm{C}$ for 1 minute. An internal reference (two samples) was additionally amplified in each plate. Standard curves for the target genes and the reference gene were constructed using 10fold serial dilutions of cDNA samples pooled from all the samples analyzed. The melting curve analysis was then programmed following the amplifications.

\section{Statistical Analysis}

For the cortisol samples, the duplicate readings for each standard, blank, and sample were averaged and then the optical density of the blank was subtracted. To be able to detect the correct amount of cortisol for each sample, a standard curve was plotted relating the intensity of the color (optical density, OD) average to the known concentrations of cortisol of the standards. Consequently each sample's cortisol concentration has been interpolated from this standard curve based on the concentrations and ODs of the 6 standards. Because the samples have been diluted, all the concentrations read from the standard curve were multiplied by the dilution factor $(1: 1)$ and normalized. All the data related to the genes relative expression from quantitative real-time PCR were calculated and normalized following the method of Livak's (1997), to enable the comparison among different treatment group and among different strains. 
Comparisons between the two strains' cortisol levels in CS and in SS and comparisons between the two strains' HSP70 and HSP90 relative expressions in CS and SS were shown graphically with 2D bar plots. In order to be able to compare these three variables (cortisol levels, HSP70 and HSP90 relative expressions) and understand how these variables are correlated between them, a Principal Components Analysis (PCA) was performed. The last statistical analysis performed is a NPMANOVA (Non-Parametric MANOVA), which is a non-parametric test of significant difference between two or more groups, based on any distance measure (Anderson, 2001) was performed on the three variables (cortisol levels, HSP70 and HSP90 relative expressions).

\section{Results}

The cortisol concentrations of the two strains of rainbow trout (Case Western and Kamloops) in the control state and the stressed state were represented graphically by 2D bars plots (Figure 3.2 and 3.3). The comparison between the two strains at the control state (Figure 3.2) shows a similar cortisol concentration. The mean for the Case Western was $13.00 \pm 19.82 \mathrm{ng} / \mathrm{ml}( \pm \mathrm{SD})$, and the mean for the Kamloops is $12.50 \pm 13.54 \mathrm{ng} / \mathrm{ml}( \pm \mathrm{SD})$ of cortisol. The comparison of the cortisol concentrations after the heat stress (Figure 3.3) shows a slightly higher cortisol concentration for the Kamloops strain with a mean of $27.40 \pm 35.48$ $\mathrm{ng} / \mathrm{ml}( \pm \mathrm{SD})$ while the Case Western has a mean concentration of $24.05 \pm 26.88 \mathrm{ng} / \mathrm{ml}( \pm$ SD). A one-way ANOVA was performed comparing the control state and the stressed state, but none of the comparisons showed a significant statistical difference between strains.

Levels of HSP70 expression for the two control groups were compared (Figure 3.4). For each strain 10 individuals HSP70 expression levels were analyzed. The 2D bars plot for this comparison shows a higher expression of the HSP70 for the Kamloops strain in control state $\left(13{ }^{\circ} \mathrm{C}\right)$. The comparison of the relative gene expression of HSP70 from the two strains 
of rainbow trout sampled immediately after the heat shock test also shows a higher gene expression for the Kamloops strain (Figure 3.5). The levels of the relative HSP90 gene expression for the two control groups (Figure 3.6) shows a higher expression of this gene for the Kamloops strain. The comparison of the relative HSP90 gene expression between the two strains after the heat stress (Figure 3.7) shows a higher expression of this gene for the Kamloops strain.

The Principal Component Analysis was performed with the objective of analyzing the correlation between the principal components and the three original variables (cortisol concentrations, relative HSP70 gene expressions, and relative HSP90 gene expressions) (Table 3.3). In Figure 3.8 the point-individuals are represented graphically in a bidimensional space, described by the first and the second components, respectively responsible for $57.04 \%$ and $32.60 \%$ of the total variance among the individuals $(89.64 \%)$. The point-individuals relative to each of the four groups under study are enclosed by complex hulls that show their dispersion in the Euclidean space (Case Western in CS, Kamloops in CS, Case Western in SS, and Kamloops in SS). The complex hull is a useful tool that delimits the dispersion area of each group, connecting between them the point-individuals more external using segments. The complex hulls are a useful tool for detecting the multivariate outliers. Furthermore, in this graphical representation the biplot is shown, it is a vectorial system that enables the description of the level of correlation of each original variable with the principal components. The first component (57.04\% of explained variance) distinguishes the group by strain and treatment: the Kamloops strain stressed is distributed in the positive part of the $\mathrm{x}$-axis (crosses dark green), the Case Western strain under stressed is dispersed in the center of the x-axis (full fuchsia squares), the Case Westerns strain under control state is distributed along the negative $\mathrm{x}$-axis (red pluses), and the Kamloops strain under control state is dispersed along the negative $\mathrm{x}$-axis in between of the two Case Western groups (empty 
blue squares). Looking at the second component $(32.60 \%)$ the four groups are dispersed in its middle portion, with half convex hull on the positive y-axis and half on the negative yaxis. The Case Western individuals in CS are mostly distributed in the II quadrant, while the Case Western individuals in SS are distributed around the center of the Cartesian plane, but both occupied the same space portion of the y-axis. The Kamloops individuals in CS, looking always at the second component, are dispersed mostly along the negative portion of the yaxis, while the Kamloops individuals in SS are majorly distributed in the positive portion of the y-axis.

A high correlation between the variables is detected when close vectors (representing the original variables in the space) form an acute angle between them. The smaller the acute angle is the higher the correlation between these two vectors. The HSPs variables are more responsible for the separation of the individuals along the first component. Furthermore, when two vectors show a $90^{\circ}$ angle between then, it means that the two vectors are not correlated between them, and this phenomena is shown between the HSP70 vector (I quadrant) and the cortisol vector (IV quadrant). A low correlation is shown between HSP90 vector (I quadrant) and cortisol vector, while the correlation between HSPs vectors is strong. Through the use of histograms that assign a correlation coefficient to each component of each original variable, it is possible to obtain the weight that each vector has in comparison to its radial orientation. In Figure 3.9, the histogram shows the correlation coefficients of each original variable with the first component. All three variables have positive correlation with the first component: cortisol with a coefficient of 0.3172 , HSP70 with a coefficient of 0.8775, and HSP90 with a coefficient of 0.9168. Looking at Figure 3.10, the histogram shows a positive correlation with the second component for the HSPs variables, with a coefficient of 0.2942 for the HSP70 and of 0.04471 for the HSP90. Instead the cortisol variable has a strong negative correlation with the second component, with a coefficient of -0.9431 . 
Non-parametric multivariate analysis of variance (NP-MANOVA, after Anderson 2001, McArdle and Anderson 2001) was used to evaluate the significance of the differences between the four groups of multivariate variables. The NP-MANOVA (Table 3.4) shows significant differences of the Kamloops strain in stress state group from the other three groups, but no significant over all variance $(\mathrm{F}=1.053 ; \mathrm{p}=0.1128)$.

\section{Discussion}

Many authors reported rainbow trout pre- and post-stress cortisol concentration levels (Table 3.5) with discordant values. Our results for CS and SS cortisol levels are in agreement with the results of Campbell et al. (1992) for rainbow trout. Campbell et al. (1992) reported values pre-stress of $13.50 \pm 4.70 \mathrm{ng} / \mathrm{ml}$ and $10.80 \pm 1.50 \mathrm{ng} / \mathrm{ml}$ of cortisol, and values poststress of $33.80 \pm 5.90 \mathrm{ng} / \mathrm{ml}$ and $26.40 \pm 3.20 \mathrm{ng} / \mathrm{ml}$, both for the Annan strain of rainbow trout. In the present study Case Western in pre-stress shows cortisol levels of $13.00 \pm 19.82$ $\mathrm{ng} / \mathrm{ml}$, while the Kamloops in pre-stress shows cortisol levels of $12.50 \pm 13.54 \mathrm{ng} / \mathrm{ml}$. Post stress Case Western shows cortisol levels of $24.05 \pm 26.88 \mathrm{ng} / \mathrm{ml}$, and Kamloops of $27.40 \pm$ $35.48 \mathrm{ng} / \mathrm{ml}$. Comparing these results in pre and post-stress between the two strains the pattern showed was the same. These results and the statistical one show that there is no difference between the Case Western strain and the Kamloops strain in the physiological stress response. This finding confirms the results of other authors that heat stressed two different strains of rainbow trout and had similar levels of cortisol concentration for both the strains used. Wagner et al. (1997) compared two different strains of rainbow trout, the Sand Creek strain and the Ten Sleep strain, and affirmed that the two strains had nearly the same levels of cortisol. Thus the physiological response to stress is related to the species and not to the strain (if different strains are kept at same environmental conditions). 
The relative HSP70 gene expression in control state shows higher values for the Kamloops strain, when compared to the Case Western. In the control state only 2 out of 10 individuals of the Case Western strain expressed the HSP70, while 9 out of 10 individuals of the Kamloops strain expressed it in the same control state. The individuals that did not show the expression of the GOI had too low an expression to be detected by real-time PCR. After the heat stress test, the relative HSP70 gene expression again showed higher values for the Kamloops strain relative to the Case Western strain. The Kamloops strain appeared to be less thermal-tolerant than the Case Western in both the conditions, showing high levels of relative expression of the HSP70 gene.

The relative HSP90 gene expression in control state shows higher values for the Kamloops strain than the Case Western strain, as well. In the control state again only 2 individuals out of 10 of Case Western strain expressed the HSP90, while all the 10 individuals of the Kamloops strain expressed it. The comparison between the expressions of HSP90 gene immediately after the heat stress (SS) showed a higher expression of the GOI for the Kamloops strain as opposed to the Case Western strain.

Looking at the results of the HSP70 and HSP90 expression from QRT-PCR analysis on the two strains of rainbow trout, it is clear that the two strains have different thermal tolerance. This statement is validated by an increase in relative expression for both HSPs shown from the Kamloops strain, while the higher thermal tolerance of the Case Western is confirmed from its lower levels of expression of HSP70 and HSP90 (in control condition most of them close to zero).

Because of the similarities in cortisol concentration levels in both states (control state and stressed state) of the two strains of rainbow trout, the study investigated if and how cortisol levels influenced the expression of the two HSPs (HSP70 and HSP90), and which 
variable most influenced the variance among groups. In order to do that a principal component analysis was performed on a multivariate matrix. Most of the variance is accounted for the first two components $(57.04 \%, 32.60 \%)$, meaning that the PCA has been very successful explaining the $89.64 \%$ of the total variance. The Jolliffe cut-off value $(0.7)$ gives an informal indication of how many principal components should be considered significant (Jolliffe, 1986). Based on this only the first and the second component are significant (Table 3.3) (being the eigenvalues of these two components higher than the Jolliffe cut-off value). The correlation of the cortisol variable to the other two variables (HSP70 and HSP90) was also investigated. Furthermore, the correlation and weight of each variable was analyzed looking at their respective influence on the overall detected variance explained by the principal component analysis.

From this analysis and from its graphic representation (Figure 3.8), the four groups are distributed well along the first component, which explains a high portion of the total variance with a percentage of $57.04 \%$. The vectors of the three variables and their radial positions explain the existent correlation between them and the variance detected. The HSPs vectors are strictly correlated between them and with the first component. The vector of the HSP90 shows that this variable, being the closest to the $\mathrm{x}$-axis, is responsible for the majority of the variance explained by the first component, confirmed by the high correlation coefficient of 0.9168 that the HSP90 variable has with the first component. The individuals that differ the most from the others groups are the ones belonging to the Kamloops strain in the stressed state. These individuals occupy the positive $\mathrm{x}$-axis, when the other three groups are located from the center part of the Cartesian plane until the negative extreme of the $\mathrm{x}$-axis The Kamloops strain, as demonstrated by this spatial distribution, is shown to be the group that differs the most from others. At the same time, the Kamloops strain is also the one that weighs the most on the distribution axis system and influenced the most variation explained 
by the principal components. Furthermore, as we can see from the Cartesian plane the cortisol variables are more correlated to the HSP90 variables than the HSP70, because their vectors are closer. The cortisol variables have a major weight on the distribution of the two groups of stressed individuals than on the two control groups, graphically shown by the presence of the cortisol vector in the IV quadrant, where there are only individuals belonging to the stressed Case Western group and to the stressed Kamloops group.

In conclusion, this research brings important new findings about the correlation between stress response at the physiological level and at the cellular level, showing that different strains of a species differ one from the other only at the cellular stress response and not at the physiological stress response. The heat shock proteins are expressed differently among strains of the same species, while the cortisol concentration levels do not differ among strains, but they are species-specific. Furthermore, the variable that influences the most the variance among different strains of rainbow trout is the HSP90 gene, and the group of individuals that differ the most from the others groups is the Kamloops strain in stressed state. 


\section{Literature cited}

Aluru, N., and Viyayan, M.M., 2008. Molecular characterization, tissue-specific expression, and regulation of melanocortin 2 receptor in rainbow trout. Endocrinology 149, 45774588.

Anderson, M.J., 2001a. A new method for non-parametric multivariate analysis of variance. Austral Ecology 26, 32- 46.

Anderson, M.J., 2001b. Permutation tests for univariate or multivariate analysis of variance and regression. Canadian Journal of Fisheries and Aquatic Sciences 58, 626-639.

Barton, B.A., and Iwama, G.K., 1991. Physiological changes in fish from stress in aquaculture with emphasis on the response and effects of corticosteroids. Ann. Rev. Fish Dis. 1, 3-26.

Barton, B.A., 2002. Stress in Fishes: A Diversity of Responses with Particular Reference to Changes in Circulating Corticosteroids. Integ. And Comp. Biol. 42, 517-525.

Basu, N., Todgham, A.E., Ackerman, P.A., Bibeau, M.R., Nakano, K., Schulte, P.M., and Iwama, G.K., 2002. Heat shock protein genes and their functional significance in fish. Gene. 295, 173-183.

Campbell, P.M., Pottinger, T.G., and Sumpter, J.P., 1992. Stress reduces the quality of gametes produced by brown and rainbow trout. Biol. Reprod. 47, 1140-1150.

Celi, M., Vazzana, M., Sanfratello, A., and Parrinello, N., 2012. Elevated cortisol modulates Hsp70 and Hsp90 gene expression and protein in sea bass head kidney and isolated leukocytes. General and Comparative Endocrinology. 175, 424-431.

Davis, M.W., 2010. Fish stress and mortality can be predicted using reflex impairment. Fish Fisher. 11, 1-11.

Feder, M.E., and Hofmann, G.E., 1999. Heat-shock proteins, molecular chaperons, and the stress response: evolutionary and ecological physiology. Annu. Rev. Physiol 61, 243282.

Feldhaus, J.F., Heppell, S.A., Mesa, M.A., Li, H., 2008. Hepatic hsp70 and Plasma Cortisol Levels in Rainbow Trout (Oncorhynchus mykiss) after tagging with a Passive Integrated Transponder. Trans Am Fish Soc 137, 690-695

Gamperl, A.K, Boutilier, R.G., 1994. Effect of acute and chronic epinephrine administration on clearance and metabolism of [3H]-epinephrine in trout (Oncorhynchus mykiss). J. Comp. Physiol. B Biochem. System. Env. Physiol. 64, 321-326.

Gamperl, A.K., Vijayan, M.M., and Boutilier, R.G., 1994. Experimental control of stress 
hormone levels in fishes: techniques and applications. Rev. Fish Biol. Fish. 4, 215255.

Iwama, G.K., McGeer, J.C., and Bernier, N., 1992. The effects of stock and rearing history on the stress response in juvenile coho salmon (Oncorhynchus kisutch). ICES Mar. Sci. Symp. 194, 67- 83.

Iwama, G.K., Vijayan, M.M., Forsyth, R.B., and Ackerman, P.A., 1999. Heat shock proteins and physiological stress in fish. Am. Zool. 39, 901-909.

Iwama, G.K., Alfonso, L.O.B., and Vijayan, M.M., 2006. Stress in fish. In: Evans D.H., Claiborne J.B. (eds). The Physiology of Fishes. 3rd Edition. Boca Raton, FL: CRC Press. Pp. 319-342.

Kincaid, H.L., Mengel, L.J., Brimm, S., 2001. National Fish Strain Registry - Trout, species tables of reported strains and broodstocks. United States Fish and Wildlife Service/United States Geological Survey, Washington DC. 165 pp.

Leatherland, J.F., Li, M., and Barkataki, S., 2010. Stressors, glucocorticoids and ovarian function in teleosts. J. Fish Biol. 76, 86-111.

Lewis, J.M., Hori, T.S., Rise, M.L., Walsh, P.J., and Currie, S., 2010. Transcriptome responses to heat stress in the nucleated red blood cells of the rainbow trout (Oncorhynchus mykiss). Physiol. Genomics. 42, 361-373.

Livak, K.J., 1997. ABI Prism 7700 sequence detection system. User Bulletin 2. Applied Biosystem.<http://www3.appliedbiosystems.com/cms/groups/mcb_support/document s/generaldocuments/cms_040980.pdf>.

McArdle, B.H., and Anderson, M.J., 2001. Fitting multivariate models to community data: a comment on distance-based redundancy analysis. Ecology 82, 290-297.

Mommsen, T.P., Vijayan, M.M., and Moon, T.W., 1999. Cortisol in teleosts: Dynamics, mechanism of action, and metabolic regulation. Rev. Fish Biol. Fish. 9, 211-268.

Pankhurst, N.W., 2011. The endocrinology of stress in fish: an environmental perspective. General and Comparative Endocrinology 170, 265-275.

Pottinger, T.G., and Pickering, A.D., 1997. Genetic basis to the stress response: Selective breeding for stress-tolerant fish. In GK Iwama, AD Pickering, JR Sumpter, and CB Schreck (eds.), Fish stress and health in aquaculture. 171-193.

Pratt, W.B., 1993. The role of the heat shock proteins in regulating the function, folding and trafficking of the glucocorticoid receptor. J. Biol. Chem. 268, 21455-21458

Quinn, N.L., McGowan, C.R., Cooper, G.A., Koop, B.F., and Davidson, W.S., 2011. Ribosomal genes and heat shock proteins as putative markers for chronic, sublethal 
heat stress in Artic charr: applications for aquaculture and wild fish. Physiol. Genomics, 43, 1056-1064.

Revollo, J.R., and Cidlowski, J.A., 2009. Mechanisms generating diversity in glucocorticoid receptor signaling. Glucocorticoids and mood: Ann. N. Y. Acad. Sci. 1179, 167-178.

Sathiyaa, R., Campbell, T., and Vijayan, M.M., 2001. Cortisol modulates HSP90 mRNA expression in primary cultures of trout hepatocytes. Comparative Biochemistry and Physiology. Part B 129, 679-685.

Schreck, C.B., 2010. Stress and fish reproduction: The roles of allostasis and hormesis. Gen. Comp. Endocrinol. 165, 549-556.

Seckl, J.R., 2004. Prenatal glucocorticoids and long-term programming. Eur. J. Endocrinol. 151, U49-U62.

Sumpter, J.P., 1997. The endocrinology of stress. In G. K. Iwama, A. D. Pickering, J. P. Sumpter, and C. B. Schreck (eds.), Fish stress and health in aqua- culture, pp. 95-118. Cambridge University Press, Cambridge.

Tasker, J.G., Di, S., and Malcher-Lopes, R., 2006. Minireview: Rapid glucocorticoid signaling via membrane-associated receptors. Endocrinology 147, 5549-5556.

Vijayan, M.M., Aluru, N., and Leatherland, J.F., 2010. Stress response and role of cortisol. In: Leatherland, J.F., Woo, P.T.K. (Eds.). Fish Diseases and Disorders, Volume 2, Non-Infectious Disorders 2nd Edition. CABI Publishing, New York. Pp.182-201.

Wagner, E.J., Bosakowski, T., and Intelman, S., 1997. Combined Effects of Temperature and High $\mathrm{pH}$ on Mortality and the Stress Response of Rainbow Trout after Stocking. American Fisheries Society. 126, 985-998.

Watts, A.G., 2005. Glucocorticoid regulation of peptide genes in neuroendocrine CRH neurons: A complexity beyond negative feedback. Front. Neuroendocriol. 26, 109130.

Wedemeyer, G.A., and McLeay, D.J., 1981. Methods for determining the tolerance of fishes to environmental stressors. In A. D. Pickering (ed.), Stress and fish, pp. 247-275. Academic Press, New York.

Wedemeyer, G.A., Barton, B.A., and McLeay, D.J., 1990. Stress and acclimation. In C. B. Schreck and P. B. Moyle (eds.), Methods for fish biology, pp. 451-489. Am. Fish. Soc.

Weinstock, M., 2005. The potential influence of maternal stress hormones on development and mental health of the offspring. Brain, Behaviour and Immunity 19, 296-308

Welch, R.M., 1993. Zinc concentrations and forms in plants for humans and animals. In: 
Robson AD, ed. Zinc in soils and plants. Dordrecht, Boston, London: Kluwer Academic Publishers, 183-195.

Wendelaar Bonga, S.E., 1997. The stress response in fish. Physiol. Rev, 77591-625. 
Table 3.1. Experimental design of the heat stress test done on Case Western strain (CW), and Kamloops strain $(\mathrm{K})$ rainbow trout.

\begin{tabular}{|c|c|c|c|}
\hline \multicolumn{5}{|c|}{ EXPERIMENTAL DESIGN } \\
\hline \multirow{2}{*}{ Day 1 } & Preliminary Bleeding & Bleed 10 individuals CW & $13 \mathrm{C}$ \\
\cline { 2 - 4 } & Preliminary Bleeding & Bleed 10 individuals K & $13 \mathrm{C}$ \\
\hline Day 2- Day 16 & \multicolumn{2}{|c|}{ Recovery } & $13 \mathrm{C}$ \\
\hline \multirow{2}{*}{ Day 17 } & Heat Stress Test & 20 individuals $(\mathrm{CW} / \mathrm{K})$ & $13 \mathrm{C}->25 \mathrm{C}(4 \mathrm{~h})$ \\
\cline { 3 - 4 } & Bleeding at $\mathrm{t}=0 \mathrm{~h}$ & 10 individuals CW & $25 \mathrm{C}(1 \mathrm{~h})$ \\
\hline Day 17 & Bleeding at $\mathrm{t}=0 \mathrm{~h}$ & 10 individuals K & $25 \mathrm{C}->13 \mathrm{C}->13 \mathrm{C}$ \\
\hline Day 17 &
\end{tabular}


Table 3.2. Primers used in real-time PCR: HSP70 f/r, HSP90 f/r, and the housekeeping gene BActin $\mathrm{f} / \mathrm{r}$.

\begin{tabular}{|l|l|c|}
\hline $\begin{array}{c}\text { Primer } \\
\text { Name }\end{array}$ & \multicolumn{1}{|c|}{ Sequence (5'-3') } & \multirow{2}{*}{$\begin{array}{c}\text { Amplicon size, } \\
\text { bp }\end{array}$} \\
\hline HSP70 - f & GGGCCAGAAGGTGTCCAATGCAGTC & \multirow{2}{*}{205} \\
\hline HSP70 - r & GCCCCCACCCAGGTCAAAAATGAC & \\
\cline { 1 - 2 } HSP90 - f & CGGGCAGTTCGGTGTGGGTTTCTAC & \multirow{2}{*}{217} \\
\cline { 1 - 2 } HSP90 - r & GACGCGCTTCTCCTCACAGTATTCAA & \multirow{2}{*}{200} \\
\cline { 1 - 2 } BActin - f & CCCATCTACGAGGACTACGC & \\
\hline BActin - r & CCCATCTCCTGCTCAAAGTC & \\
\hline
\end{tabular}


Table 3.3. The eigenvalues values, giving a measure of the variance accounted for by the corresponding eigenvectors (components) are given below for the two significant components. The percentages of variance accounted for by these components are also given.

\begin{tabular}{|c|c|c|}
\hline PC & Eigenvalue & \%variance \\
\hline 1 & 1.71131 & 57.044 \\
\hline 2 & 0.978074 & 32.602 \\
\hline
\end{tabular}


Table 3.4. Results of a non-parametric MANOVA to test for significant differences between the four groups under study, based on correlation distance measure (Anderson 2001). Shaded cells represent those group pairs with significant correlation.

\begin{tabular}{|c|c|c|c|c|}
\hline & CW_CS & K_CS & CW_SS & K_SS \\
\hline CW_CS & 0 & 1 & 0.4605 & $\mathbf{0 . 0 0 0 1}$ \\
\hline K_CS & 1 & 0 & 1 & $\mathbf{0}$ \\
\hline CW_SS & 1 & 1 & 0 & $\mathbf{0 . 0 0 1 2}$ \\
\hline K_SS & $\mathbf{0 . 0 0 0 6}$ & $\mathbf{0}$ & $\mathbf{0 . 0 0 7 2}$ & 0 \\
\hline
\end{tabular}


Table 3.5. Literature cortisol levels for stressed and unstressed (control) rainbow trout (Oncorhynchus mykiss)

\begin{tabular}{|c|c|c|}
\hline \multicolumn{3}{|c|}{ Cortisol levels for rainbow trout (Oncorhynchus mykiss) } \\
\hline Authors & Treatement type & Cortisol value (ng/ml) \\
\hline Campbell et al., 1992 & Pre-stress male & $13.5 \pm 4.7$ \\
\hline Campbell et al., 1992 & Pre-stress female & $10.8 \pm 1.5$ \\
\hline Ruane et al., 1999 & Pre-stress & $1.9 \pm 0.4$ \\
\hline Basu et al., 2001 & Pre-stress & $1.7 \pm 0.8$ \\
\hline Barton, 2002 & Pre-stress & $1.7 \pm 0.5$ \\
\hline Campbell et al., 1992 & Post-stress male (handling) & $26.4 \pm 3.2$ \\
\hline Campbell et al., 1992 & Post-stress female (handling) & $33.8 \pm 5.9$ \\
\hline Ruane et al., 1999 & Post-stress (after $4 \mathrm{~h}$ confinement) & $43.4 \pm 7.9$ \\
\hline Ruane et al., 1999 & Post-stress (after $48 \mathrm{~h}$ confinement) & $7.8 \pm 4.4$ \\
\hline Basu et al., 2001 & $\begin{array}{l}\text { Post-stress (heat stress of } 2 \mathrm{~h} \text {, measurements } \\
\text { after } 3 \mathrm{~h} \text { from the stress) }\end{array}$ & $127.8 \pm 8.5$ \\
\hline Basu et al., 2001 & Post-stress (after $24 \mathrm{~h}$ from the heat stress) & $63.6 \pm 24.7$ \\
\hline Basu et al., 2001 & Post-stress (after $72 \mathrm{~h}$ from the heat stress) & $71.5 \pm 17.6$ \\
\hline Barton, 2002 & Post-stress (handling) & $43 \pm 3.5$ \\
\hline Jentoft et a., 2005 & Post repeated stress (after 30 minutes) & $147 \pm 17$ \\
\hline Jentoft et a., 2005 & Post repeated stress (after $1 \mathrm{~h}$ ) & $70 \pm 21$ \\
\hline Jentoft et a., 2005 & Post single stress & $177 \pm 18$ \\
\hline
\end{tabular}




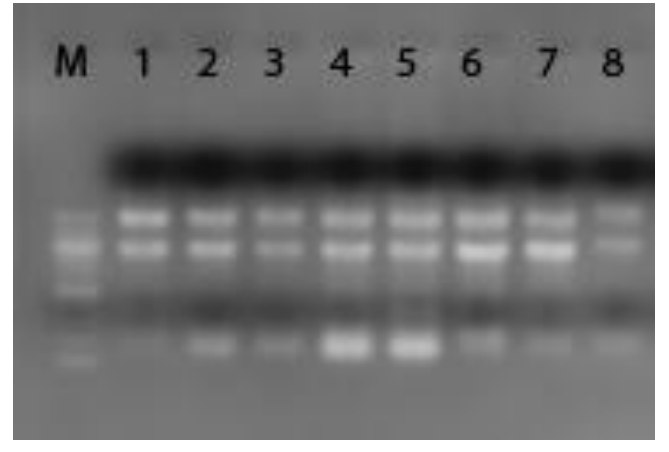

Figure 3.1. Agarose gel electrophoresis of RNA extracted from 8 samples. 


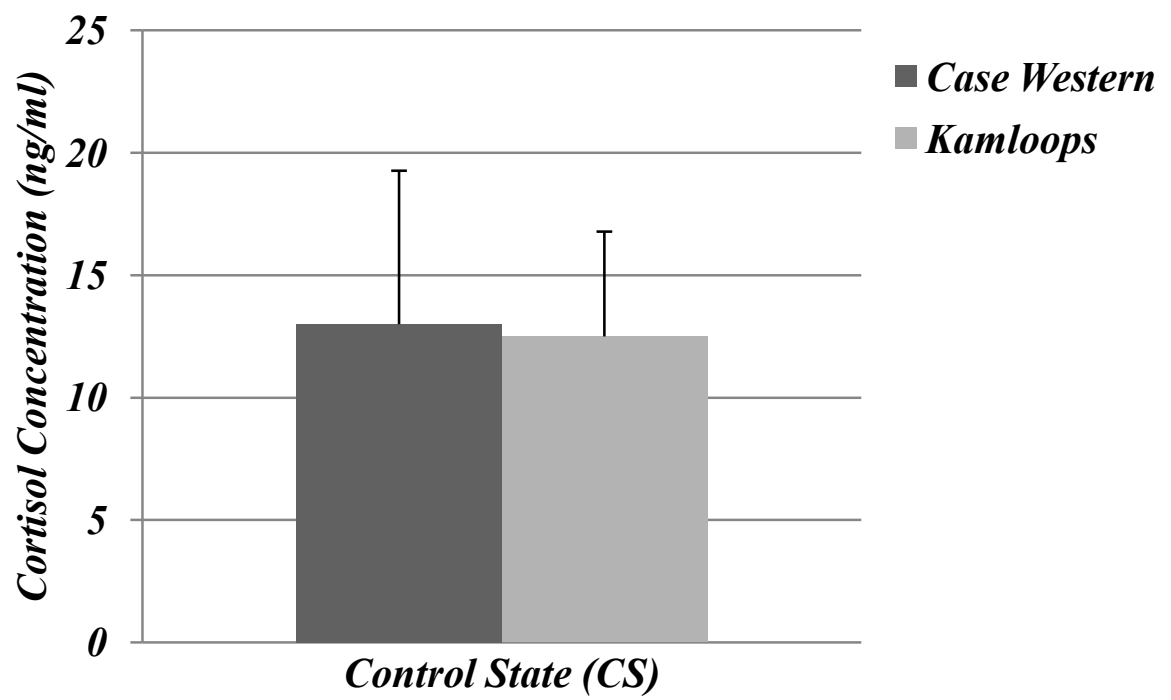

Figure 3.2. Comparison of the plasma cortisol concentration levels of the two strains of rainbow trout (O. mykiss) sampled as control two weeks before the heat shock test. Vertical bars represent the plasma cortisol concentrations $(\mathrm{ng} / \mathrm{ml})$, and lines represent traces of individual response based on 10 individuals per strain. The error bars represent the standard deviation from the mean (SD). The dark grey column represents the Case Western control group, and the light grey column represents the Kamloops control group. 


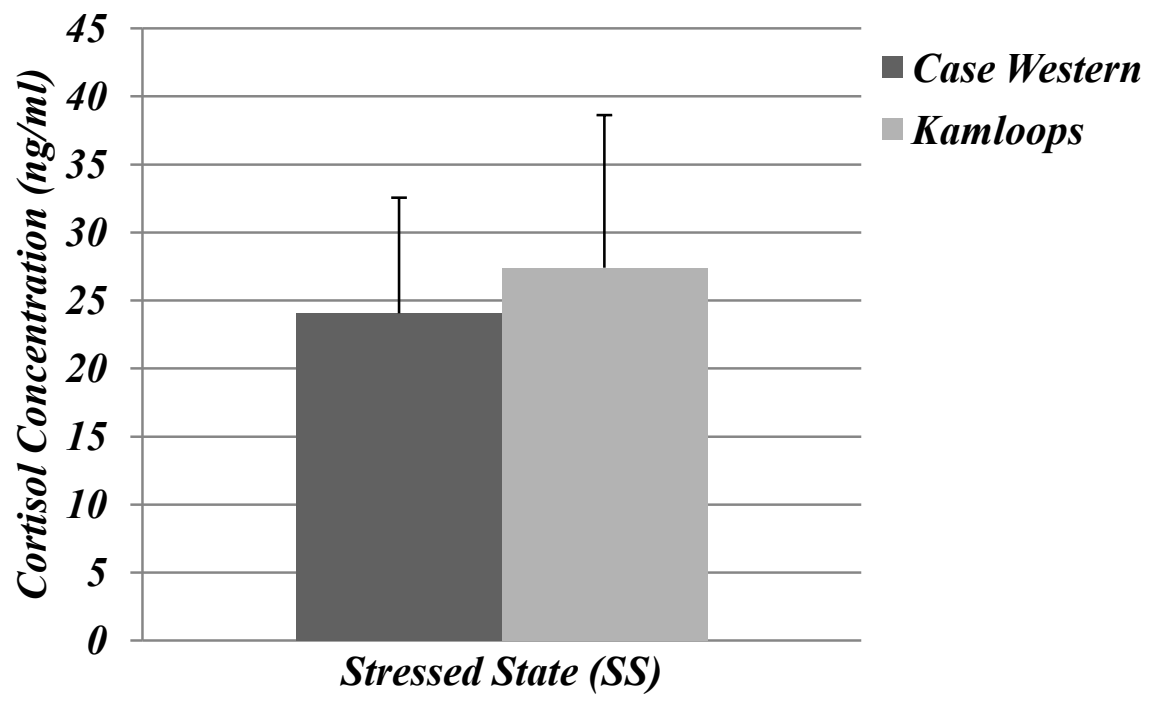

Figure 3.3. Comparison of the plasma cortisol concentration levels of the two strains of rainbow trout $(O$. mykiss) sampled immediately after the heat shock test. Vertical bars represent the plasma cortisol concentrations $(\mathrm{ng} / \mathrm{ml})$, and lines represent traces of individual response based on 10 individuals per strain. The error bars represent the standard deviation from the mean (SD). The dark grey column represents the Case Western control group, and the light grey column represents the Kamloops control group. 


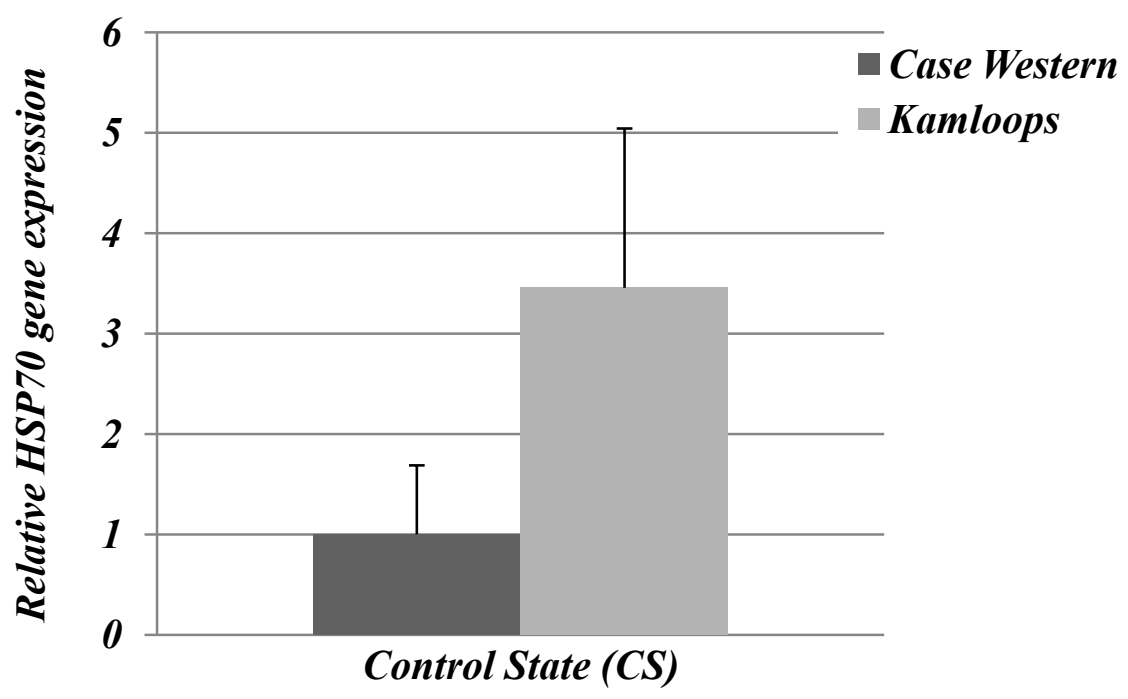

Figure 3.4. Comparison of the relative gene expression of HSP70 from QRT-PCR analysis on the two strains of rainbow trout (O. mykiss) red blood cells (RBCs) sampled as control two weeks before the heat shock test. Vertical bars represent the relative gene expression values, and lines represent traces of individual response based on 10 individuals per strain. The error bars represent the standard error of the mean (SEM). The dark grey column represents the Case Western control group, and the light grey column represents the Kamloops control group. 


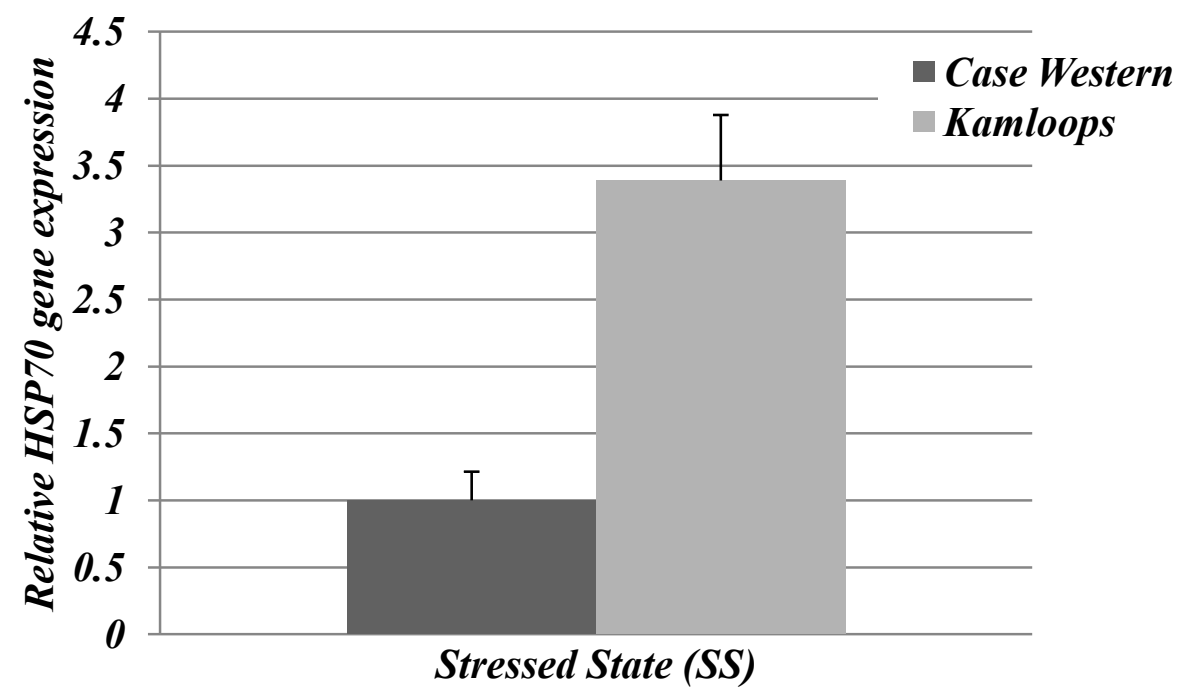

Figure 3.5. Comparison of the relative gene expression of HSP70 from QRT-PCR analysis on the two strains of rainbow trout $(O$. mykiss) red blood cells (RBCs) sampled immediately after the heat shock test. Vertical bars represent the relative gene expression values, and lines represent traces of individual response on 10 individuals per strain. The error bars represent the standard error of the mean (SEM). The dark grey column represents the Case Western control group, and the light grey column represents the Kamloops control group. 


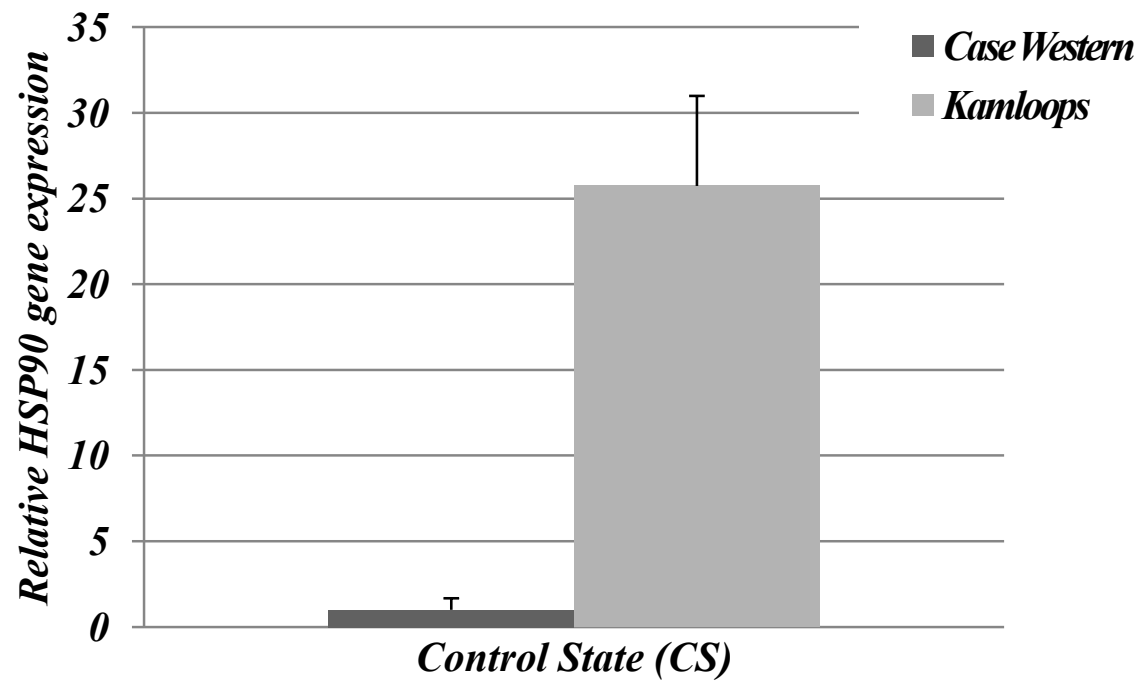

Figure 3.6. Comparison of the relative gene expression of HSP90 from QRT-PCR analysis on the two strains of rainbow trout (O. mykiss) red blood cells (RBCs) sampled as control two weeks before the heat shock test. Vertical bars represent the relative gene expression values, and lines represent traces of individual response based on 10 individuals per strain. The error bars represent the standard error of the mean (SEM). The dark grey column represents the Case Western control group, and the light grey column represents the Kamloops control group. 


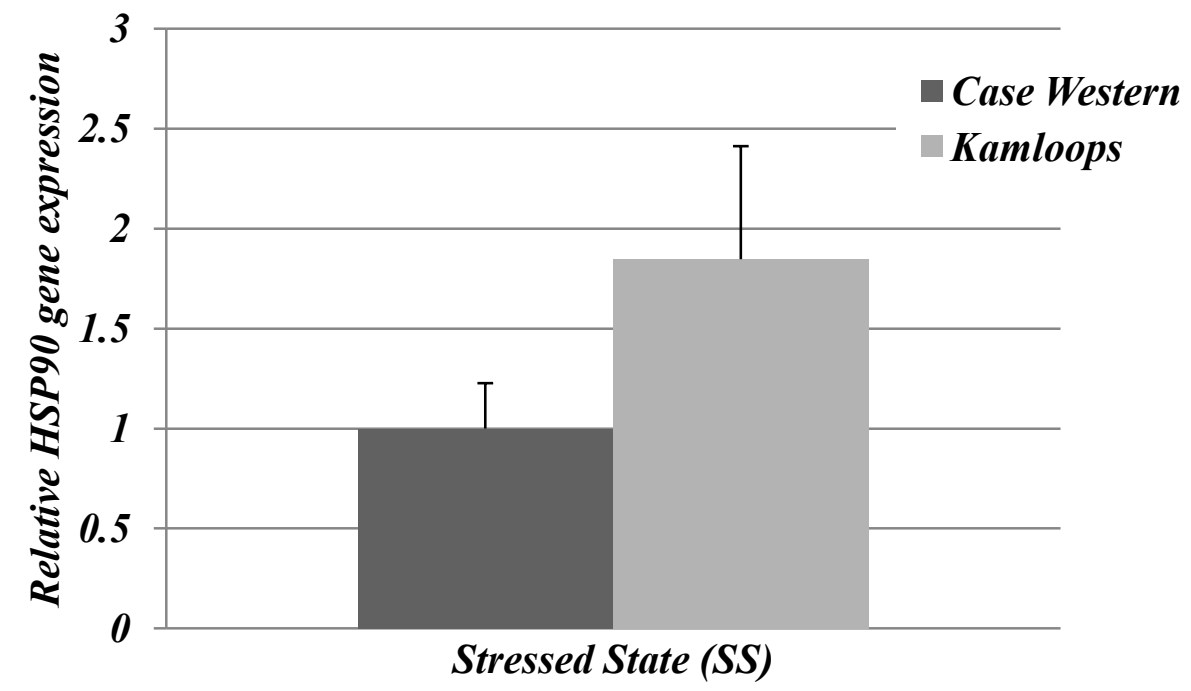

Figure 3.7. Comparison of the relative gene expression of HSP90 from QRT-PCR analysis on the two strains of rainbow trout $(O$. mykiss) red blood cells (RBCs) sampled immediately after the heat shock test. Vertical bars represent the relative gene expression values, and lines represent traces of individual response on 10 individuals per strain. The error bars represent the standard error of the mean (SEM). The dark grey column represents the Case Western control group, and the light grey column represents the Kamloops control group. 


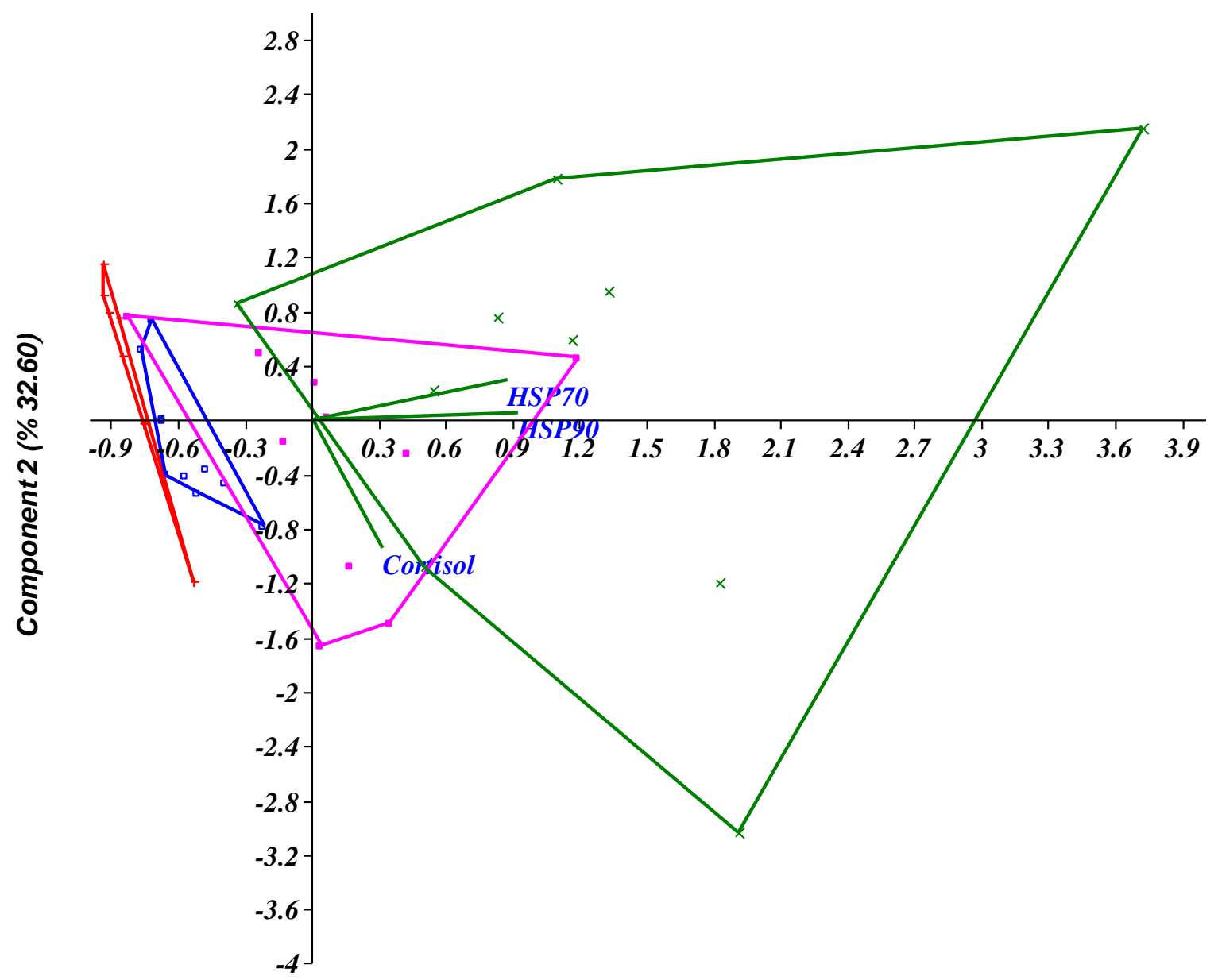

Component 1 (\% 57.04)

Figure 3.8. Principal Component Analysis graph, showing the first $(57.04 \%$ of variance explained) and second (32.60\% of variance explained) components. The convex hulls show the distribution of the four groups under study: Case Western strain in control state (red pluses), Kamloops in control state (blue empty squares), Case Western in stressed state (fuchsia squares), and Kamloops in stressed state (green crosses). 


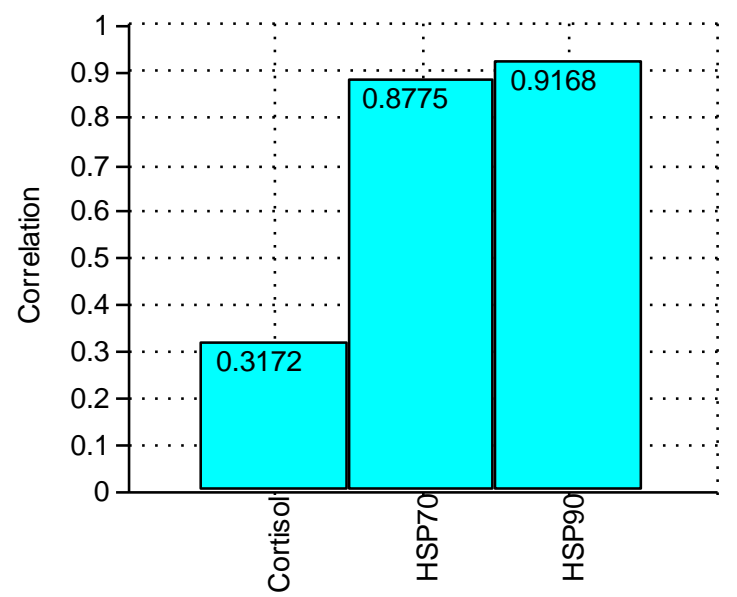

Figure 3.9. Histogram showing the correlation coefficients of each original variable with the first component. 


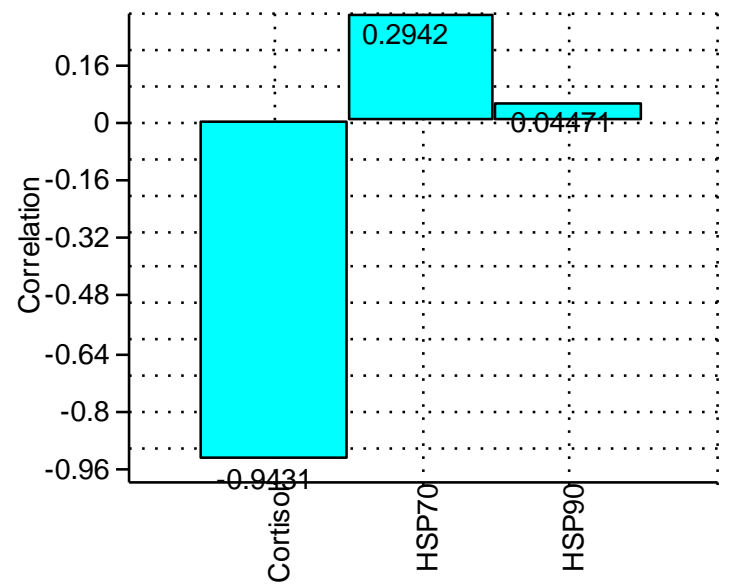

Figure 3.10. Histogram showing the correlation coefficients of each original variable with the second component. 